\title{
INFLUÊNCIA DA INTRUSÃO COMBINADA À RETRAÇÃO ANTERIOR SOBRE O GRAU DE REABSORÇÃO APICAL CONSEQÜENTE À MOVIMENTAÇÃO DENTÁRIA INDUZIDA
}

DOUGLAS TIBOLA

Dissertação apresentada à Faculdade de Odontologia de Bauru da Universidade de São Paulo, como parte dos requisitos para obtenção do título de Mestre em Odontologia, área de Ortodontia.

BAURU 


\section{INFLUÊNCIA DA INTRUSÃO COMBINADA À RETRAÇÃO ANTERIOR SOBRE O GRAU DE REABSORÇÃO APICAL CONSEQÜENTE À MOVIMENTAÇÃO DENTÁRIA INDUZIDA}

DOUGLAS TIBOLA

Dissertação apresentada à Faculdade de Odontologia de Bauru da Universidade de São Paulo, como parte dos requisitos para obtenção do título de Mestre em Odontologia, área de Ortodontia.

Orientador: Prof. Dr. Décio Rodrigues Martins

BAURU 
TIBOLA, Douglas

T434i Influência da intrusão combinada à retração anterior sobre o grau de reabsorção apical conseqüente à movimentação dentária induzida / Douglas Tibola -Bauru, 2007.

119p. mais apêndice: il.; $30 \mathrm{~cm}$.

Dissertação (Mestrado) - Faculdade de Odontologia de Bauru. Universidade de São Paulo.

Orientador: Prof. Dr. Décio Rodrigues Martins

Autorizo, exclusivamente pra fins acadêmicos e científicos, a reprodução total ou parcial desta tese, por processo fotocopiadores e/ou meios eletrônicos.

Assinatura do autor:

Data:

Comitê de Ética da FOB-USP

Protocolo n.: $36 / 2005$

Data: 29/11/2006 


\section{DADOS CURRICULARES}

\section{DOUGLAS TIBOLA}

\begin{tabular}{|c|c|}
\hline $\begin{array}{l}29 \text { de setembro de } 1977 \\
\text { Marau - RS }\end{array}$ & Nascimento \\
\hline Filiação & $\begin{array}{l}\text { José Tibola } \\
\text { Catarina Rita Tibola }\end{array}$ \\
\hline $1995-2000$ & $\begin{array}{l}\text { Curso de graduação em Odontologia pela } \\
\text { Faculdade de Odontologia da } \\
\text { Universidade de Passo Fundo }\end{array}$ \\
\hline $2000-2002$ & $\begin{array}{l}\text { Curso de especialização em Radiologia } \\
\text { Odontológica e Imaginologia pela APCD } \\
\text { Central - São Paulo/SP }\end{array}$ \\
\hline 2001-2003 & $\begin{array}{l}\text { Curso de aperfeiçoamento em Ortodontia } \\
\text { pela ACOPEN (Assessoria e Consultoria } \\
\text { em Ortodontia, Pesquisa e Ensino-Bauru) }\end{array}$ \\
\hline $2003-2005$ & $\begin{array}{l}\text { Curso de Especialização em Ortodontia } \\
\text { pela APCD Bauru - Bauru/SP }\end{array}$ \\
\hline $2005-2007$ & $\begin{array}{l}\text { Curso de Pós-graduação em Ortodontia, } \\
\text { em nível de Mestrado, na Faculdade de } \\
\text { Odontologia de Bauru, Universidade de } \\
\text { São Paulo (FOB - USP) }\end{array}$ \\
\hline
\end{tabular}




\section{Dedicatória $e$}

Agradecimentos 


\title{
Dedico este trabalho
}

Aos meus pais, José e Rita, pelo apoio incondicional mesmo nas decisões duvidosas e pela preocupação ao longo de todo esse longo tempo e grande distância. Ele, trabalhador incansável... Ela, professora primária, aposentada, que sempre viu no estudo o melhor caminho para a vida. Com certeza a posição em que estou muito se deve à herança de humildade, persistência e muito trabalho adquirida.

\section{Agradeço profundamente}

\author{
ÀDEUS, \\ Acima de tudo, por permitir tudo isso ter acontecido e \\ estar acontecendo na minha vida.
}

Ao Prof. Dr. Décio Rodrigues Martins, meu orientador, pela paciência e prontidão disponibilizada, desde o primeiro contato de orientação. Também pelas dicas incessantes e muitas vezes repetitivas, para que definitivamente fossem lembradas. Não há como esquecer, sua postura extremamente correta, conduta rígida e sempre buscando a perfeição, na prática e até mesmo na escrita, no intuito de se formar os "Ortodontistas de 'O' maiúsculo", mas sempre respeitando as limitações de seus alunos. Também, agradeço por ter permanecido por praticamente uma década, ministrando aulas mesmo após aposentado, permitindo assim ter sido seu aluno. Sinto muito orgulho de ter sido orientado pelo "Dr. Décio Rodrigues Martins". 


\section{Minha gratidão}

Ao Prof. Dr. Marcos Roberto de Freitas, Coordenador do Programa de Pós-Graduação em Ortodontia, ao nível de Doutorado, pela maneira bem humorada e descontraída de conduzir sua disciplina.

Ao Prof. Dr. José Fernando Castanha Henriques, pelos votos de confiança, pela simpatia e pela sempre disposição em ajudar.

Ao Prof. Dr. Guilherme Janson, Coordenador do Programa de Pós-Gradução ao nível de Mestrado, pela sua busca incansável por descobertas em favor da ciência e dinamismo, contribuindo muito com seus ensinamentos para meu desenvolvimento científico, técnico e pessoal.

Ao Prof. Dr. Arnaldo Pinzan, pelo carinho, amizade e entrosamento. Guardo lembranças, de quando o vi pela primeira vez, contando piadas para um grupo de alunos. Percebi, naquele momento, que havia algo diferente.

Ao Prof. Dr. Renato Rodrigues de Almeida, pelo gosto e entusiasmo em repassar seus conhecimentos. Isso semeia uma vontade cada vez maior de aprender para cada vez mais ensinar. 
Ao Prof. José Roberto Lauris, pela presteza e dedicação com que sempre trabalhou, procurando transformar a repassar seus conhecimentos estatisticos de forma bastante simples.

Ao Prof. Dr. Alberto Consolaro, pelo exemplo de profissionalismo e amor à profissão. Seus exemplos de conduta como professor e de valorização do relacionamento humano servirão de alicerce para o início e em toda nossa carreira. E inesqueciveis são os presenciados durante a disciplina de Prática Docente, tenho certeza entre todos nós, ex-alunos da disciplina.
Aos colegas do Mestrado em Ortodontia, Caio, Danilo, Eduardo, Janine, Leonardo, Luís Filiphe, Luís Fernando, Mayara, Patrícia, Rachelle, Tassiana e Vladimir. Os anos de convívio foram muito bons e serão inesquecíveis.

Aos amigos do Doutorado, Alexandre Nakamura, Carlos Cabrera, Carlos Guimarães, Darwin Vaz de Lima, Fernando Torres, Fernando Pedrin, Kelly Chiqueto, Lívia Freitas, Marcus Crepaldi, Marise Cabrera, Paula Oltramari, Rafael Henriques, Renata Castro e Sérgio Estelita, pelas dicas sempre repassadas e pelo convívio e amizade.

Aos colegas que já passaram pelo Departamento, Analu, Célia, Fernanda, José Eduardo, Ricardo, Rodrigo e em especial ao Fabricio, Maria Fernanda, Karina Freitas, Karina Lima, Leniana e Rejane pelas dicas e ajuda prestada. 
Aos amigos que ajudaram diretamente e indiretamente na confecção desta tese, em especial à Kelly, Natália, Sérgio, Luciana e Alexandre... todas as formas de ajuda foram bem-vindas e necessárias.

\begin{abstract}
Ao meu irmão Giovani, Ortodontista e precursor da minha carreira, que nunca mediu esforços para tentar ajudar e resolver os problemas, mesmo os que não estavam a seu alcance, facilitando sobremaneira a conclusão deste trabalho.
\end{abstract}

Aos meus parentes que mesmo distantes, estiveram sempre muito preocupados e curiosos com o desenvolver do curso e da minha "carreira de estudante".

Aos funcionários da ACOPEN, onde tudo começou... Sônia, Luciana, César e Valter; e do Departamento de Ortodontia, Cristina, Neide, Sérgio, Vera, Luciana, Bonné e Danilo por toda a amizade, bom-humor e discontração durante o nosso convívio.

A Faculdade de Odontologia de Bauru, representada por seu diretor Prof. Dr. Luís Fernando Pegoraro; à Comissão da Pós-Graduação, representada pela Profa. Dra. Maria Aparecida de Andrade Moreira Machado e à CAPES pela bolsa concedida favorecendo o desenvolvimento da pesquisa e do curso de Mestrado. 


\section{SUMÁRIO}

LISTA DE FIGURAS . . . . . . . . . . . . . . . . . . . . . .xii

LISTA DE TABELAS . . . . . . . . . . . . . . . . . . . . xiv

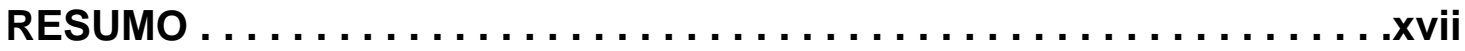

1. INTRODUÇÃO . . . . . . . . . . . . . . . . . . . . 1

2. REVISÃO DA LITERATURA $\ldots \ldots \ldots \ldots \ldots \ldots \ldots \ldots \ldots \ldots$

2.1 A sobremordida. . . . . . . . . . . . . . . . . . 7

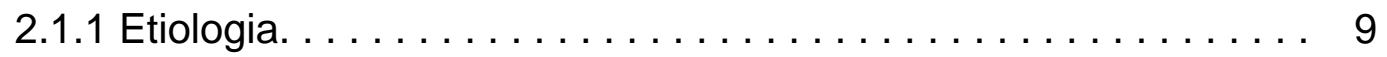

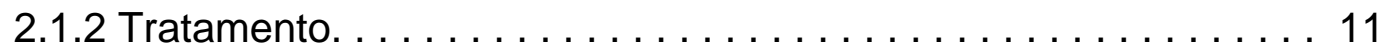

2.2 A sobressaliência. . . . . . . . . . . . . . . . . . 13

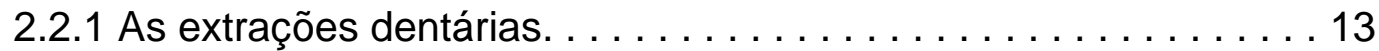

2.3 As reabsorções dentárias. . . . . . . . . . . . . . . . 15

2.3.1 Localização . . . . . . . . . . . . . . . . . . . . . . . . 16

2.3.2 Mecanismo . . . . . . . . . . . . . . . . . . 17

2.3.3 Classificação . . . . . . . . . . . . . . . . . . 18

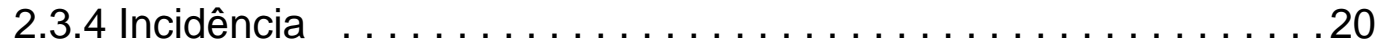

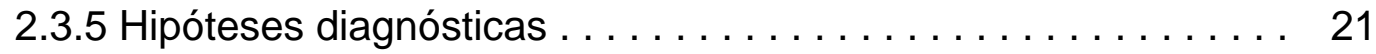

2.3 .6 As causas . . . . . . . . . . . . . . . . . . . . . . . . . . 24

2.3.6.1 Fatores relacionados ao paciente . . . . . . . . . . 25

2.3.6.2 Fatores relacionado ao tratamento ortodôntico . . . . . . . . 27

2.3.7 Detecção e avaliação . . . . . . . . . . . . . . . . . . 30

3. PROPOSIÇÃo . . . . . . . . . . . . . . . . . . . 33

4. MATERIAL E MÉTODOS . . . . . . . . . . . . . . . . . . . . . 37

4.1 Material . . . . . . . . . . . . . . . . . . . 39

4.1 .1 Critérios de seleção da amostra . . . . . . . . . . . 39

4.1.2 Características da amostra . . . . . . . . . . . 41

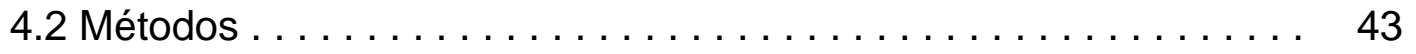


4.2.1 Avaliação das radiografias periapicais . . . . . . . . . . 43

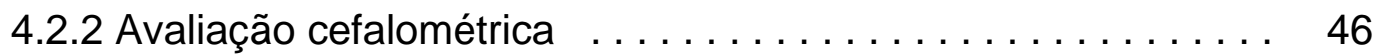

4.2.2.1 Desenho anatômico . . . . . . . . . . . . . . . . . 47

4.2.2.2 Demarcação dos pontos cefalométricos . . . . . . . . . 48

4.2.2.3 Planos e linhas de referências . . . . . . . . . . . . . . 49

4.2.2.4 Grandezas cefalométricas . . . . . . . . . . . . . . 50

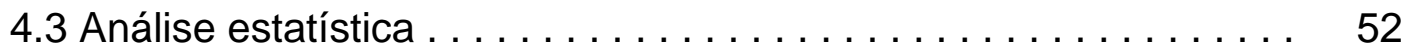

4.3.1 Erro do método e concordância inter-examinadores . . . . . . . 52

4.3.2 Análise estatística entre grupos e variáveis . . . . . . . . . . . 52

5 RESULTADOS . . . . . . . . . . . . . . . . . . . . . . . 55

5.1 Erro do método e concordância inter-examinadores . . . . . . . . 57

5.2 Compatibilização entre os grupos . . . . . . . . . . . . . . . 59

5.3 Análise descritiva do grau de reabsorção radicular . . . . . . . . . 61

5.4 Avaliação das variáveis cefalométricas . . . . . . . . . . . . . . . . . 61

5.5 Correlação entre o grau de reabsorção e as variáveis . . . . . . . . 63

5.6 Comparação do grau de reabsorção entre os dentes . . . . . . . . . 64

6 DISCUSSÃo . . . . . . . . . . . . . . . . . . . . . 65

6.1 Considerações relacionadas à amostra $\ldots \ldots \ldots \ldots \ldots$

6.2 Considerações relacionadas à metodologia . . . . . . . . . . . . . 73

6.2.1 Medição da quantidade de reabsorção radicular. . . . . . . . . . 73

6.2.2 Medição dos trespasses . . . . . . . . . . . . . . . 76

6.2.3 Medição dos movimentos dentários. . . . . . . . . . . . . 77

6.2.4 Digitalização das imagens radiográficas. . . . . . . . . . . 77

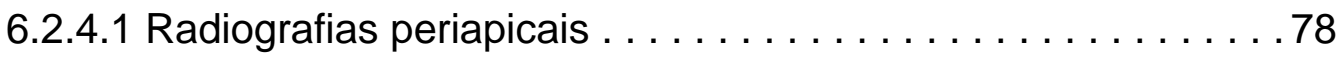

6.2.4.2 Telerradiografias. . . . . . . . . . . . . . . . . . . . . . 79

6.2 .5 Precisão da metodologia. . . . . . . . . . . . . . . . . . . 79

6.3 Discussão dos resultados . . . . . . . . . . . . . . . . . . . . . . 81

6.3 .1 Compatibilização entre os grupos . . . . . . . . . . . . . 81

6.3.2 Comparação do grau de reabsorção entre os grupos. . . . . . . . 82

6.3.3 Alterações das variáveis entre os grupos . . . . . . . . . . . . . 84

6.3.4 Correlações entre as variáveis. . . . . . . . . . . . . . 86 
6.3.5 Comparação da reabsorção entre os incisivos . . . . . . . . . 88

6.4 Implicações clínicas . . . . . . . . . . . . . . . . . . 89

6.5 Sugestões para novos trabalhos . . . . . . . . . . . . . 92

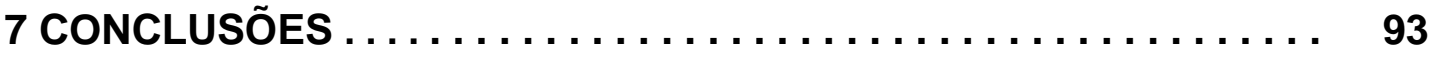

REFERÊNCIAS BIBLIOGRÁFICAS . . . . . . . . . . . . . . . . . 97

ABSTRACT . . . . . . . . . . . . . . . . . . . . . . . . 117

APÊNDICE 


\section{LISTA DE FIGURAS}

FIGURA 1 - Classificação dos graus de reabsorção, segundo

MALMGREN et al..

FIGURA 2 - Radiografias periapicais inicial (a) e final (b) de incisivo central com grau 0 de reabsorção

FIGURA 3 - Radiografias periapicais inicial (a) e final (b) de incisivo lateral com grau 1 de reabsorção.

FIGURA 4 - Radiografias periapicais inicial (a) e final (b) de incisivo lateral com grau 2 de reabsorção.

FIGURA 5 - Radiografias periapicais inicial (a) e final (b) de incisivo lateral com grau 3 de reabsorção.

FIGURA 6 - Radiografias periapicais inicial (a) e final (b) de incisivo central com grau 4 de reabsorção.

FIGURA 7 - Padronização do brilho e contraste entre as radiografias iniciais e finais.

FIGURA 8 - Padronização do tamanho entre as radiografias iniciais e finais.

FIGURA 9 - Traçado anatômico

FIGURA 10 - Pontos cefalométricos utilizados 
FIGURA 11 - Linhas e planos de referência.................................................. 50

FIGURA 12 - Grandezas Cefalométricas .................................................. 51 


\section{LISTA DE TABELAS}

TABELA 1 - Avaliação da concordância na classificação do grau de reabsorção intra e inter-examinadores (teste de concordância kappa ponderado).

TABELA 2 - Avaliação dos erros sistemáticos e casuais das medições cefalométricas intra-examinador (teste "t" pareado e fórmula de Dahlberg).

TABELA 3 - Avaliação dos erros sistemáticos e casuais das medições cefalométricas inter-examinadores (teste " $\mathrm{t}$ " pareado e fórmula de Dahlberg).

TABELA 4 - Médias e desvios padrão das idades iniciais, tempos de tratamento, quantidades de sobressaliência e de sobremordida, e a compatibilização entre os grupos (teste " $t$ " independente) 60

TABELA 5 - Compatibilização da distribuição dos diferentes gêneros entre os grupos 1 e 2 (teste qui-quadrado).

TABELA 6 - Comparação da quantidade de reabsorção entre os grupos (teste Mann-Whitney)

TABELA 7 - Distribuição quantitativa e percentual dos dentes de acordo com o grau de reabsorção radicular apresentado em ambos os grupos

TABELA 8 - Média das variáveis cefalométricas nas fases T1 e T2. 
TABELA 9 - Alterações das variáveis cefalométricas entre as fases T2T1 e a comparação entre os grupos (teste " $t$ " independente). 62

TABELA 10 - Avaliação da correlação do grau de reabsorção com o tempo de tratamento, com as alterações na sobremordida e sobressaliência e com os movimentos verticais e horizontais dos incisivos centrais durante as fases T2-T1 (teste de correlação de Spearman)

TABELA 11 - Comparação do grau de reabsorção radicular entre os incisivos centrais e laterais, dos grupos 1 e 2 (teste de Wilcoxon). . 64 
Resumo 


\section{RESUMO}

$\boldsymbol{O}$

objetivo deste estudo foi avaliar a influência da força de intrusão na ocorrência da reabsorção radicular dos incisivos superiores, de pacientes tratados com extrações de pré-molares. Para tanto, foram selecionados 56 pacientes com sobressaliência acentuada, tratados com extrações pela técnica Edgewise simplificada, sendo que metade deles apresentava concomitantemente sobremordida profunda, corrigida com arcos de nivelamento incorporando acentuação e reversão da curva de Spee, sendo este último denominado Grupo 1. Essa amostra foi obtida no arquivo da disciplina de Ortodontia da Faculdade de Odontologia de Bauru - USP, sendo que o Grupo 1 possuía 28 pacientes com sobremordida e sobressaliência acentuadas com médias de 4,78 $\pm 1,18 \mathrm{~mm}$ e 6,48 $\pm 2,52 \mathrm{~mm}$, respectivamente, apresentando idade média de 13,41 $\pm 2,38$ anos. O Grupo 2 contava também com 28 pacientes apenas com a sobressaliência acentuada, com média de 5,67 $\pm 2,73 \mathrm{~mm}$, sobremordida normal, com média de 1,12 \pm 0,97 mm e apresentando idade média de 13,27 \pm 1,85 anos, ao início do tratamento. Utilizaram-se radiografias periapicais pré e pós-tratamento para avaliar o grau de reabsorção radicular classificando-a nos escores de Malmgren, e comparou-se entre os dois grupos pelo teste Mann-Whitney. Além disso, verificou-se a correlação entre o grau de reabsorção com os trespasses iniciais, com a quantidade de correção desses trespasses, com as quantidades de movimentação apical vertical e horizontal, obtidos pela avaliação das telerradiografias iniciais e finais, e o tempo de tratamento, utilizando o coeficiente de correlação de Spearman. Também uma comparação entre os incisivos centrais e laterais foi executada, em ambos os grupos, para definir qual foi mais afetado, utilizando-se o teste de Wilcoxon. Os resultados revelaram maior reabsorção no grupo tratado com mecânica intrusiva, uma correlação estatisticamente significante da reabsorção com a quantidade de sobremordida inicial e com seu grau de correção, e diferente grau de reabsorção entre os incisivos apenas no grupo 2, onde os incisivos laterais apresentaram-se mais afetados, porém com diferença estatística não significante. 
Palavras-chave: Ortodontia. Reabsorção da Raiz. Movimentação Dentária. Intrusão Dentária. 
INTRODUÇÃo 


\section{1 - INTRODUÇÃO}

E mbora a reabsorção radicular possa ocorrer fortuitamente com o envolver da idade ${ }^{145,146}$, a reabsorção radicular ocasionada pela movimentação dentária induzida intriga muitos profissionais, que buscam incansavelmente respostas para a ocorrência deste fenômeno.

É freqüentemente citada na literatura como uma iatrogenia ${ }^{58,89,159,224}$, decorrente da atuação de fatores locais que eliminam a camada de cementoblastos. A concentração de forças no periodonto, no ligamento periodontal e principalmente no terço apical pode provocar desequilíbrio na homeostase local resultando em reabsorções dentárias. Os incisivos superiores mostram-se mais susceptíveis à reabsorção devido às suas características radiculares, que impulsiona a força ortodôntica diretamente ao ápice, e por serem geralmente os mais movimentados.

Dos movimentos dentários, a intrusão ${ }^{69,157}$, bem como a retração $0^{93}$, são intensamente relacionados à reabsorção, por serem movimentos caracterizados como agressivos e lesivos às estruturas periodontais ${ }^{64,69,70,130,136,154,195}$. Porém, nenhum trabalho tem demonstrado a responsabilidade de cada movimento na quantidade de reabsorção, quando ambos ocorrem de maneira combinada.

Realizou-se este estudo considerando que muitas dúvidas persistem em relação ao potencial de reabsorção radicular resultante da mecânica de intrusão e/ou da retração, devido às diversas metodologias aplicadas, à ausência de homogeneidade e de critérios bastante rigorosos na obtenção das amostras, impossibilitando as comparações alcançarem resultados bastante específicos, visto existirem muitas variáveis que contribuem para o aparecimento das mesmas, tornando os estudos às vezes não totalmente conclusivos ou confiáveis. Avaliou-se também a intensidade da reabsorção apical em incisivos superiores pela análise comparativa em pacientes ortodonticamente tratados submetidos à extração de pré-molares, com e sem sobremordida profunda, a fim de se avaliar a influência da mecânica de intrusão sobre o grau de reabsorção apresentado em casos de retração anterior, realizando algumas comparações e correlações oportunas. 
Revisão Da

Literatura 


\section{2 - REVISÃO DA LITERATURA}

\subsection{A Sobremordida}

1 uitas más oclusões apresentam como uma de suas vertical entre os incisivos e caninos superiores e inferiores, isto é, ambas as arcadas se trespassam com diversos níveis de acentuação. Esse fenômeno é denominado sobremordida, que pode ser caracterizada por normal e profunda.

A sobremordida profunda apresenta características próprias, na maioria das vezes, encontra-se associada a outras anormalidades da oclusão, sendo de difícil correção e manutenção ${ }^{182,223}$. O trespasse existente entre os incisivos quando em oclusão, isto é, com os dentes posteriores em contato, é denominado sobremordida, quando analisado no sentido vertical, e sobressaliência quando no horizontal ${ }^{107}$.

Observam-se diferentes metodologias na literatura para avaliação da quantidade da sobremordida. Em 1949, NEFF ${ }^{165}$ utilizou os modelos de gesso para avaliar a oclusão. O método para verificar a quantidade de sobremordida consistia na medição direta da extensão em que o incisivo superior sobrepunha o inferior. Dessa forma, a simples mensuração da quantidade que o incisivo superior sobrepõe o incisivo inferior é considerada confiável $^{140,165}$. Considerou um trespasse normal quando $20 \%$ do incisivo inferior se apresentasse sobreposto.

PRAKASH; MARGOLIS ${ }^{183}$, em 1952, considerou que um plano vertical deveria servir como referência, e utilizou a altura facial anterior definida pelo comprimento da linha násio-pogônio para realizar a avaliação.

BJÖRK $^{27}$, por sua vez, em 1969 determinou cefalometricamente uma linha da face distal do primeiro molar inferior permanente até a borda incisal do incisivo superior, medindo a quantidade que o incisivo inferior ultrapassava essa linha.

Em 1975, JACOBSON ${ }^{108}$ divulgou uma análise na qual as medidas eram realizadas baseadas numa linha que passava pelo ponto médio de 
intercuspidação dos molares e pré-molares. Segundo o autor, essa linha retrata o plano oclusal, que reproduziria com mais fidelidade as alterações existentes, pois evitaria o mascaramento das mesmas quando pontos ou estruturas distantes são tomadas como referência. Afirmava também que a maxila e mandíbula, bem como as estruturas distantes, poderiam apresentar rotações horárias e anti-horárias interferindo consideravelmente sobre a magnitude das discrepâncias reais. Denominou essa técnica de avaliação como Análise de Wits. Seu princípio é avaliação das relações ântero-posteriores das bases ósseas, mas pelos motivos supra citados tem sido empregada na apreciação de outras variáveis.

A quantidade de trespasse definida como normal não é conceitualmente bem definida e quantificada, pois depende de vários fatores relacionados à ampla variação individual, como o tamanho dentário e a idade, por exemplo. Na dentadura decídua, a sobremordida normal se apresenta com uma relação de topo-a-topo entre os incisivos ${ }^{160}$. Na mista, com os dentes anteriores permanentes já em erupção, há um aprofundamento temporário da mordida, que diminui quando da erupção dos posteriores permanentes $11,21,79,88,103,160,18079,160,180$

Considera-se como normal um trespasse dos incisivos superiores em 1/3 da coroa dos incisivos inferiores ou entre 1 a $3 \mathrm{~mm}^{191}$, apesar de apresentar uma ampla variação individual e até mesmo alterações com o envolver da idade ${ }^{99}$.

Em determinadas situações o comportamento da sobremordida, quanto ao aumento ou diminuição, torna-se imprevisível. BERGERSEN ${ }^{21}$, em 1988, constatou que aproximadamente $80 \%$ das sobremordidas maiores que 3 $\mathrm{mm}$ aos 12 anos preservaram ou aumentaram os seus valores. Isto sugere 0 caráter não autocorrigível desta má oclusão, com a manutenção ou agravamento da sobremordida com o desenvolvimento da dentição e da oclusão 21,103

A curva de Spee torna-se acentuada na mesma proporção, ou seja, quanto maior a sobremordida, maior a acentuação da curva, e torna-se necessário nivelá-la, tanto por razões funcionais, como para restabelecer a normoclusão, finalidades do tratamento ortodôntico ${ }^{84}$. Sua correção é 
imprescindível, pois altera os padrões normais de fechamento bucal e os movimentos mandibulares, podendo até ser causador de distúrbios temporomandibulares ${ }^{90,160,183}$.

Deve ser instituído um plano de tratamento individualizado para cada paciente, seja por extrusão dos dentes posteriores e/ou intrusão dos anteriores, avaliando-se o biótipo facial. A etiologia da sobremordida deve ser verificada para determinar o tipo de tratamento indicado ${ }^{10,74,162,180,199,200,211}$.

\subsubsection{Etiologia}

Os fatores relacionados com o desenvolvimento da sobremordida podem ser de origem esquelética e/ou dentoalveolar.

As opiniões divergem quanto à etiologia dessa má oclusão, pois, enquanto alguns advogam a falta de crescimento vertical nas regiões dos molares e dos pré-molares, outros apontam a responsabilidade à supraerupção dos incisivos e caninos e, outros ainda, admitem a combinação de ambas as causas ${ }^{134,184}$. Há outros fatores passíveis de desenvolver uma sobremordida profunda, tais como a perda prematura dos molares decíduos; a respiração bucal, com conseqüente protrusão dos incisivos superiores; a função anormal dos músculos da mastigação; a seqüência alterada de erupção dentária; a permanência prolongada de dentes decíduos; a má posição e a extrusão dentária ${ }^{11}$.

Analisando modelos de gesso, de diferentes casos com sobremordida profunda, STEADMAN ${ }^{221}$, em 1949, observou uma associação direta da curva de Spee com o trespasse vertical aumentado. Para seu diagnóstico, uma análise criteriosa dessa curva deveria ser realizada em ambos os arcos, pois o tipo de tratamento e o seu sucesso dependeriam da determinação correta da etiologia e da cooperação do paciente.

Sabe-se também que a curva de Spee é influenciada pelo trespasse horizontal, que é citado como um dos contribuintes para o aumento da sobremordida por favorecer a erupção dos incisivos até que estes encontrem algum obstáculo ou contato entre eles, para cessar o processo ${ }^{15,213}$. 
Por obstáculo, se exemplifica a mucosa do palato para os incisivos inferiores, e uma consistência do lábio inferior oferecendo resistência à erupção, para os incisivos superiores ${ }^{184}$.

BJORK $^{28}$ afirma, em 1953, haver uma correlação entre o trespasse horizontal e a sobremordida, ou seja, quanto maior a sobressaliência, mais profunda se torna a mordida.Os fatores esqueléticos responsáveis pela variabilidade da sobremordida são o desenvolvimento dos côndilos mandibulares que pode provocar uma rotação anti-horária da mandíbula ${ }^{27,211}$ e o desenvolvimento vertical da maxila, que implica no abaixamento do plano palatino $^{211}$. A altura facial ântero-inferior e o ângulo goníaco encontram-se diminuídos ${ }^{49,190}$, bem como a altura da sínfise mentoniana. Uma maior distância entre as espinhas nasais anterior e posterior e uma maior área na maxila também ocorrem ${ }^{49}$.

Com o propósito de examinar os padrões de desenvolvimento e crescimento facial em jovens que apresentam alterações na sobremordida de origem esquelética, NANDA ${ }^{163}$, em 1988, avaliou longitudinalmente radiografias laterais de jovens com mordida aberta e sobremordida profunda e notou que cresceram diferentemente. O grupo com sobremordida profunda caracterizouse pelo aumento da altura facial ântero-superior. A altura facial posterior e a altura do ramo não apresentaram diferença significante entre os jovens com mordida aberta e sobremordida profunda. Apesar de ocorrerem pequenas alterações durante o crescimento e desenvolvimento, uma vez estabelecido o padrão facial, a sua manutenção e constância constituem a regra. Os pacientes com padrão de face curta, com sobremordida profunda, apresentam um ritmo de crescimento do terço ântero-superior maior que o inferior, mantendo ou acentuando as proporções faciais e a má oclusão, tornando-se apenas mais evidente durante o surto de crescimento pubescente ${ }^{135,165}$.

No ano seguinte, NANDA; ROWE ${ }^{164}$ realizaram uma análise longitudinal do crescimento craniofacial em jovens com mordida aberta e sobremordida profunda esqueléticas, caracterizados pela altura facial ânteroinferior respectivamente aumentada ou diminuída. Estabeleceram que há definição do padrão facial dos jovens da amostra pelo menos três anos antes do surto de crescimento e perceberam que não houve alteração durante o 
período da adolescência. Este estudo sugere que os padrões de desenvolvimento se estabelecem antes do surto de crescimento pubescente. Os jovens com mordida aberta apresentaram uma maturação esquelética mais precoce do que os com sobremordida profunda e as diferenças morfológicas entre os grupos foram mantidas durante todo o surto de crescimento.

A participação do lábio no desenvolvimento da sobremordida profunda foi descrita por VAN DER LINDEN ${ }^{239}$, onde o posicionamento mais alto do lábio inferior promove um pressionamento sobre os incisivos superiores em erupção de tal forma que proporciona a verticalização dos mesmos e ocasiona sua supra-erupção. Secundariamente, os incisivos inferiores também adquirem uma posição mais retruída e extruída, caracterizando um trespasse vertical acentuado.

\subsubsection{Tratamento}

Os dentes anteriores apresentam uma função muito importante, a de proteger os dentes posteriores. Tão importante é a função da guia anterior que os dentes posteriores que não estiverem protegidos contra esforços protrusivos ou laterais podem ser submetidos à esforços de intensidade superior àquela que suas estruturas de suporte possam resistir. Daí a importância de se ter as guias corretas de oclusão ${ }^{68}$.

A correção da sobremordida no tratamento ortodôntico torna-se então imprescindível por todos os fatores já citados, e para tanto é fundamental realizar o plano de tratamento baseado na etiologia da má oclusão. É necessário realizar uma avaliação criteriosa do problema instalado, para a confecção do plano de tratamento e a escolha do tipo de aparelho empregado na correção da discrepância.

A literatura apresenta vários tipos de aparelhos utilizados para o tratamento dessa má oclusão. O tipo facial, a estética apresentada pela exposição dos incisivos superiores, a relação dos incisivos inferiores com o plano oclusal funcional, a relação ântero-posterior dos arcos dentários, a 
função mastigatória, a saúde do periodonto e a estabilidade que o tratamento oferecerá, são quesitos básicos a serem analisados ${ }^{88,242}$.

Basicamente, quatro tipos de movimentos dentários são realizados na correção: intrusão na região anterior ${ }^{41,74,134,201,213,215}$, extrusão na posterior $^{23,162}$, inclinação dos incisivos ${ }^{5,54,74,77,84,199,200,207}$ e crescimento diferencial das estruturas ósseas ${ }^{19,23,116,149,158,173,176,192,199,200,207,244}$. Dependendo dos problemas encontrados e dos objetivos de tratamento, qualquer um destes movimentos isolados ou associados podem ser usados para reduzir a sobremordida ${ }^{116,154,199,200,242}$.

A intrusão dos incisivos é indicada nos pacientes que apresentam exposição excessiva dos incisivos superiores, em repouso ou durante 0 sorriso $^{23}$. O arco base de intrusão e o arco utilidade são as duas técnicas utilizadas com este objetivo. Não incluem os pré-molares, são ativados no tubo molar originando uma força de intrusão na região anterior ${ }^{41,215}$. Uma menor quantidade de extrusão posterior ocorre na técnica do arco base ${ }^{177,244}$.

A extrusão dos dentes posteriores pode ser conseguida pela utilização das placas de mordida, onde o contato na região anterior impede o contato dos dentes posteriores, permitindo o desenvolvimento dentoalveolar dessa área ${ }^{23,162}$.

O procedimento do uso do arco de nivelamento com curva reversa no arco inferior e acentuada no superior é outra abordagem comum para a correção da sobremordida acentuada. Eles proporcionam uma força combinada de intrusão nos dentes anteriores e de extrusão nos posteriores $5,19,23,26,41,54,68,74,90,116,149,158,199-201,213$. Um arco inferior com curva reversa age principalmente inclinando distalmente os molares e vestibularmente os incisivos ${ }^{5,54,74,77,84,199,200}$. A inclinação para vestibular contribui para a correção do trespasse vertical ${ }^{207}$ e em períodos longos de uso os pré-molares extruem e os incisivos e molares sofrem uma intrusão, porém este último em menor quantidade ${ }^{184}$.

Estes movimentos concentram muita tensão no ápice, por isso são freqüentemente associados à maior reabsorção radicular $^{16,31,35,36,58,69,97,130,150,155,157,177,186,196,213,214,240,245,246}$. 
MITCHELL ${ }^{158}$, em 1973, afirmou que a quantidade de intrusão dos dentes anteriores obtida com o tratamento pode ser medida utilizando-se como referência a borda incisal dos incisivos ${ }^{133,148,149,207}$. Mas para BURSTONE ${ }^{41}$, em 1977, isto dificulta a distinção entre intrusão real e inclinação, e o movimento dentário deveria ser avaliado a partir do seu centro de resistência no intuito de minimizar o efeito da inclinação durante a mensuração da quantidade de intrusão obtida.

A inclinação que ocorre nos dentes deve-se à força aplicada fora do centro de resistência do dente, produzindo um movimento de rotação do longo eixo ${ }^{41,218}$, ou seja, a coroa irá vestibularizar ao passo que o ápice, em menor quantidade, irá lingualizar. A localização desse centro de resistência é determinada pelo comprimento, forma e número de raízes, sua quantidade de inserção e altura do osso alveolar ${ }^{23,53}$, e para BURSTONE ${ }^{41}, 1977$, localiza-se na raiz a 2/5 da distância entre a crista alveolar e o ápice radicular, confirmado por $\mathrm{CHOY}$ et al. ${ }^{53}$ em 2000. A inclinação vestibular será maior quanto mais distante for o ponto de aplicação da força ao centro de resistência do dente.

SAKIMA ${ }^{199,200}$, em 2000, realizou duas publicações, onde afirma que os movimentos dentários verticais podem ser mascarados pelo efeito do crescimento alveolar que ocorre nos pacientes em fase de crescimento, tanto na região anterior como na posterior.

\subsection{A Sobressaliência}

\subsubsection{As extrações dentárias}

Desde o século XVIII realizavam-se extrações de pré-molares para corrigir o apinhamento e a protrusão dos dentes anteriores, conseguindo um aspecto mais agradável ${ }^{40,202}$.

A partir daquela época, várias foram as terapias empregadas, desde a extração preventiva de elementos decíduos, como também, já no século XIX, as extrações de molares permanentes, para favorecer 0 
alinhamento dos dentes, suscitando inúmeras discussões e opiniões contrárias $^{40,202}$.

Angle foi o autor que mais se contrapôs à terapia extracionista, defendendo o conceito de desenvolvimento funcional: os dentes deveriam ser colocados em suas posições corretas, alinhados, nivelados e articulados entre si, para que a função pudesse estimular o crescimento das bases ósseas, conseguindo-se assim, espaço para todos os dentes ${ }^{40,202}$.

TWEED ${ }^{232}$, ao aplicar os princípios idealizados por Angle, sem extração, frustrou-se com os aspectos clínicos dos resultados obtidos, normalmente com biprotrusões e perfis faciais antiestéticos, além das inevitáveis recidivas pós-tratamento. A partir de 1936, passou a contrariar seu mestre, admitindo extrações de quatro primeiros pré-molares, para obter um melhor posicionamento dos incisivos em suas inclinações axiais corretas, e em 1941, idealizou e passou a preconizar as extrações modificando completamente os princípios da mecânica expansionista ${ }^{40,202,234}$.

GRIEVE $^{90}$, em 1944, concluiu também que a maioria de seus casos, tratados ortodonticamente sem extração, haviam sofrido recidiva. Seu primeiro caso com a extração de 4 pré-molares lhe permitiu uma verticalização e intrusão dos incisivos inferiores, conseguindo a correção do plano oclusal, e um melhor resultado da estética facial. Segundo o autor, sempre que a extração de 4 dentes for indicada, normalmente os dentes de escolha são os primeiros pré-molares.

As extrações dentárias devem sempre ser consideradas como uma alternativa, nos casos com espaços insuficientes para as necessidades de movimentação dentária. ${ }^{112,232-234}$, A decisão de se extrair ou não dentes como parte do tratamento ortodôntico pode influenciar o resultado final, incluindo o perfil facial, a estética, a oclusão, a satisfação do paciente, assim como a duração do tratamento.

Em 1995, BISHARA; CUMMINS; JAKOBSEN ${ }^{24}$ avaliaram casos tratados com e sem extração. O grupo com extrações, de quatro primeiros prémolares, apresentava uma maior discrepância de modelo em ambos os arcos, lábios superiores e inferiores mais protruídos nos homens, e somente o lábio 
inferior nas mulheres. A posição dos lábios foi nesse grupo determinante para a decisão das extrações. Esta preocupação do impacto das extrações no perfil facial faz parte de vários outros trabalhos na literatura relacionados à quantidade de retração dos incisivos superiores e seu efeito sobre os lábios, ângulo nasolabial, tamanho e forma do nariz, além do impacto sobre o sorriso e o corredor bucal.

A escolha do dente a ser extraído deve ser cuidadosamente analisada. Esta análise deve ser guiada pelo grau de discrepâncias entre as massas dentária e a óssea e pela relação oclusal apresentada, além do impacto que causará no perfil facial. Em casos de apinhamento severo, a escolha é quase sempre por primeiros pré-molares ${ }^{85,236,237}$. A terapia com extrações apresenta como seqüela principal a presença freqüente de reabsorções ao final do tratamento $3,3,4,13,43-45,47,70,80,83,109,115,179,226$.

\subsection{As Reabsorções Dentárias}

A reabsorção radicular, por sua complexidade de detecção, tratamento e previsibilidade, bem como por sua impossibilidade de regeneração, tem se tornado alvo de diversos estudos. Nos dentes decíduos é conseqüente a um processo fisiológico, pois suas raízes apresentam uma predisposição inerente à reabsorção. Porém, nos dentes permanentes, como as raízes não apresentam essa fisiologia, não deveria ocorrer essa alteração, o que infelizmente acontece em condições especiais.

Antigamente, a ortodontia em sua maior parte era realizada em crianças, adolescentes, e adultos jovens. Esses grupos de pacientes são os que, na maioria das vezes, apresentam maior grau de normalidade física, sistêmica e local. Atualmente, o tratamento estende-se, em número considerável, aos adultos e alguns até com idade avançada. Nestes pacientes, é comum encontrar-se coroas clínicas maiores devido às raízes com suporte ósseo reduzido por reabsorção alveolar ou extrusão, dentes já submetidos à diversos tipos de traumas, presença de bolsas e doença periodontal, uso de 
próteses e implantes dentários, tecido ósseo apresentando alterações como escleroses, e incidência de maior número de doenças ${ }^{58}$.

Percebe-se então que são maiores as complicações apresentadas por um paciente adulto, e isso atua indiretamente sobre a incidência da reabsorção radicular quando submetido à correção ortodôntica.

\subsubsection{Localização}

As reabsorções radiculares são freqüentes e podem ser classificadas como fisiológicas e patológicas, bem como internas e externas ao elemento dentário. Também coronárias ou radiculares, e até mesmo combinadas.

As internas são geralmente causadas por traumatismos, cáries, pulpites, restaurações profundas, podendo atingir as porções radicular ou coronária e são geralmente chamadas de centrípetas, ou seja, as áreas afetadas são pouco amplas e profundas, sendo mais localizadas. As externas geralmente afetam os dentes irrompidos, sendo elas localizadas na porção radicular ou na junção amelocementária, geralmente chamadas de centrífugas, ou seja, com áreas afetadas amplas, rasas e irregulares.

As coronárias afetam apenas os dentes não irrompidos. Quando externa, é causada por trauma no germe ou infecção. Já as cervicais, seus causadores são os agentes químicos, os traumas, a movimentação ortodôntica, reimplantes, dentre outros.

As radiculares podem estar localizadas nas faces laterais, afetando a porção média da raiz, causadas por agentes químicos, movimentação ortodôntica, lesões periapicais crônicas, reimplantes, expansão rápida ${ }^{238}$, sendo esse tipo de reabsorção a mais freqüente, e seu diagnóstico geralmente é tardio. Podem, também, estarem localizadas na região apical da raiz, sendo dessa forma de fácil diagnóstico radiográfico, sendo o tipo de reabsorção mais "detectável". Esta porção radicular não apresenta uma formação tecidual com maior predisposição à reabsorção, apenas sua anatomia favorece o 
aparecimento e a detecção da mesma ${ }^{58}$. O mecanismo pelo qual se estabelece um processo de reabsorção dentária, resumidamente, será descrito a seguir.

\subsubsection{Mecanismo}

As células do corpo humano possuem um formato específico, que é mantido pelo seu citoesqueleto, ou seja, uma espécie de esqueleto celular, formado por proteínas. Geralmente ocorre um equilíbrio neste formato, denominado de tensigridade. Se essa tensigridade for alterada por alguma ação sobre o citoesqueleto (causada por algum agente físico, químico ou biológico citado anteriormente) ocorre a formação de um estresse na célula, causando uma super-estimulação metabólica que por sua vez provoca a liberação de muitas substâncias, denominadas mediadores, para restabelecer a tensigridade perdida. Esses mediadores são "sentidos" por outras células por receptores "específicos" existentes na superfície de suas membranas celulares, e provocam fenômenos celulares, teciduais e vasculares como o aumento da permeabilidade da membrana celular, incremento na entrada de cálcio na célula, que ativa determinadas enzimas que apresentam como produto final, após um longo ciclo, sinais e sintomas de dor e inflamação, cuja finalidade é utilizar certos artifícios para restabelecer a normalidade à região afetada. Convém salientar que as células só respondem mediante um estímulo ou mensagem de algum mediador.

As raízes dos dentes são recobertas por um tecido chamado cemento, que possui uma camada superficial de células, os cementoblastos, insensíveis à esses mediadores químicos e hormônios desencadeadores da reabsorção óssea. São, dessa forma, uma espécie de protetores da raiz, pois as áreas que estão cobertas por estas células estão protegidas de todo esse processo de reabsorção.

HIDALGO ${ }^{104}$, em 2001, demonstrou que uma vez removida a camada de cementoblastos expondo a dentina, ocorre a formação de anticorpos anti-dentina. A inflamação existente nesta área afetada impede a recolonização da região pelos cementoblastos adjacentes, iniciando e 
perpetuando um processo de reabsorção dentária. Cessada a inflamação, os cementoblastos repovoam a área lesada e a reabsorção é interrompida.

O reparo de um processo de reabsorção ocorre quando pequenas áreas de necrose dos cementoblastos são repovoadas e compensadas pela migração de cementoblastos vizinhos. As áreas maiores de necrose são supridas de osteoblastos adjacentes, os denominados cementoblastos-like, que produzem tecido mineralizado semelhante ao cemento. Convém lembrar que, em níveis mais elevados de mediadores da reabsorção, os mesmos funcionam como unidades osteorremodeladoras, ou seja, como parte de um conjunto celular que promove a reabsorção. Por isso é necessário um cuidado redobrado quando o tratamento for executado em dentes traumatizados e em retratamentos, pois a presença de cementoblastos-like é um fato a ser considerado $^{83}$.

Esta unidade de remodelação, denominada anteriormente de osteorremodeladora, não exerce ação sobre as raízes dentárias pois as mesmas estão recobertas por cementoblastos. Porém, em áreas onde estas células não estão presentes, o processo de reabsorção se instala. Para estas células não existirem, é necessário que algum agente agressor as tenha necrosado, ou seja, causado sua morte. Por isso levanta-se a dúvida sobre que tipo de agente pode causar a morte dessa camada de cementoblastos.

Em ortodontia todo esse processo desenvolve-se no espaço preenchido pelo ligamento periodontal, onde estão presentes essas células especializadas, com apenas $0,25 \mathrm{~mm}$ de espessura, sendo $50 \%$ de sua composição formada por vasos, que facilitam os processos de inflamação e regeneração ${ }^{58}$.

\subsubsection{Classificação}

De uma forma bem ampla, a reabsorção pode ser classificada em fisiológica, quando ocorre nos dentes decíduos e patológica, nos dentes permanentes. 
ANDREASEN ${ }^{8}$, em 1985, classificou a reabsorção radicular externa em 3 tipos principais, de acordo com sua etiologia e patogenia: a reabsorção de superfície, causada pela agressão ao ligamento periodontal, podendo ser reparada se a agressão não persistir; a reabsorção inflamatória, conseqüente à combinação entre agressão ao ligamento periodontal e à superfície radicular, com a presença de bactérias presentes no canal radicular e, por último, a reabsorção por substituição, decorrente da fusão entre o osso adjacente e a superfície radicular.

TRONSTAD ${ }^{231}$, em 1988, distinguiu dois tipos de reabsorção: a inflamatória transitória, quando o agente etiológico é mínimo e atua por um curto período, e a reabsorção inflamatória progressiva, quando o fator etiológico estende-se por um longo período.

Em 1993, PUCHE ${ }^{185}$ considerou que as reabsorções podem ser reversíveis e irreversíveis. Reversíveis quando causadas pela compressão do ligamento periodontal, resultante de uma carga oclusal excessiva, e irreversíveis na reabsorção fisiológica dos dentes decíduos para serem substituídos pelos sucessores, na reabsorção de incisivos laterais superiores durante a erupção dos caninos, na reabsorção provocada pelo movimento fisiológico dos dentes e, ainda, na idiopática.

$\mathrm{Na}$ realidade, didaticamente, quanto ao mecanismo de ocorrência, as reabsorções podem ser classificadas em inflamatórias ou por substituição. As reabsorções inflamatórias decorrem de um agente agressor, que ocasiona a lesão externa e/ou interna e da ação de mediadores acumulados no exsudato inflamatório. As reabsorções por substituição são conseqüentes à uma anquilose alveolodentária prévia, onde danos irreversíveis ao ligamento permitem ligação direta do cemento ao osso alveolar. Com o tempo, o dente vai sendo reabsorvido e a parte reabsorvida é substituída por osso, formandose novas trabéculas ósseas. O processo se estende para a coroa e para a raiz, respeitando sempre o limite pulpar, devido à presença da pré-dentina. Na maior parte das reabsorções por substituição há também um componente inflamatório, enquanto que na reabsorção de origem inflamatória geralmente não ocorre anquilose. 
Quanto à localização, a reabsorção pode ser considerada interna, externa ou combinada ${ }^{58}$.

Deste modo, pode-se considerar que a reabsorção radicular decorrente do tratamento ortodôntico seja patológica, inflamatória e externa ${ }^{230}$.

Atualmente, a classificação mais utilizada quando relacionada à movimentação dentária é a de MALMGREN et al. ${ }^{141}$ idealizada em 1982, que classificaram as reabsorções de acordo com a gravidade em ausente, leve, moderada, acentuada e extrema.

\subsubsection{Incidência}

A ortodontia como recurso terapêutico era utilizada ignorando quaisquer conseqüências até 1927, quando KETCHAM ${ }^{118}$ num estudo radiográfico atentou para a freqüente ocorrência de reabsorção radicular em pacientes tratados ortodonticamente.

HENRY; WEINMAN ${ }^{102}$ em 1951, num estudo realizado em cadáveres, demonstraram após exames radiográficos e histológicos que 90,5\% dos dentes analisados apresentavam sinais de reabsorção, sendo que $76,8 \%$ das áreas reabsorvidas situavam-se no terço apical da raiz, e aqueles dentes não haviam sido induzidos à movimentação.

As vantagens de um tratamento ortodôntico é que ele objetiva a correção do posicionamento dos dentes e dos arcos dentários, restabelece a boa oclusão tanto estática como funcionalmente, melhora a saúde dos tecidos de sustentação, bem como a estética facial, mas apresenta como uma de suas conseqüências, a maior incidência de reabsorção.

Para LINGE; LINGE ${ }^{136}$, de 1983, o "custo" biológico dos tratamentos pode ser representado por seqüelas indesejáveis e irreversíveis que às vezes ocorrem. A concentração de forças no ligamento periodontal e principalmente no terço apical pode provocar desequilíbrio na homeostase local resultando em reabsorções das raízes dentárias, geralmente suaves ${ }^{216}$ mas às 
vezes severas, podendo comprometer a longevidade da estrutura dentária, dependendo de sua magnitude ${ }^{35,36}$.

HARRIS; KINERET; TOLLEY ${ }^{95}$, em 1997, asseguram que a causa mais freqüente de reabsorção radicular é a movimentação dentária induzida, não obstante esteja presente em 7 a 10\% da população não tratada, sendo que 1/10 dos pacientes ortodônticos desenvolvem reabsorção grave, durante o tratamento.

FURQUIM $^{83}$ constatou a presença de reabsorção em $44,3 \%$ dos pacientes que nunca foram submetidos ao tratamento ortodôntico em seu trabalho de 2002. Embora também ocorra nesses indivíduos ${ }^{96,102,145}$, a prevalência em pacientes tratados é significativamente mais alta ${ }^{83,96,102,145,247}$, numa incidência que varia entre $88 \%{ }^{43}$ até $100 \%$ dos $\operatorname{casos}^{216}$.

Constatada a freqüente ocorrência da reabsorção radicular em pacientes ortodonticamente tratados, pesquisadores estudam esse processo para explicar o porquê e quantificar essa manifestação, e os resultados desses estudos têm gerado muitas controvérsias.

\subsubsection{Hipóteses diagnósticas}

A primeira evidência do fenômeno da reabsorção segundo HENRY; WEIMANN ${ }^{102}$ em 1951, e MASSLER; MALONE ${ }^{145}$ de 1954, foi relatada por BATES $^{12}$, no ano de 1856, ao afirmar que a reabsorção era consecutiva ao trauma do ligamento periodontal.

O primeiro registro científico a respeito da influência do tratamento ortodôntico nas reabsorções dentárias foi de OTTOLENGUI ${ }^{174}$, em 1914, e comprovada através de radiografias por KETCHAM ${ }^{118}$, em 1927. Desde então, inúmeras pesquisas foram realizadas no intuito de se encontrar as causas do problema.

Ao se analisar radiografias dos dentes e maxilares e perceberemse alterações nas morfologias óssea e dentária, como variações do trabeculado, a falta de uniformidade e integridade das corticais, o aumento de 
volumes intra e extra-ósseo, as reabsorções radiculares múltiplas sem causa aparente, logo eram resgatadas as alterações sistêmicas, em especial os distúrbios metabólicos e as endocrinopatias ${ }^{35,36}$ para explicá-las. Da mesma forma, o caráter genético ${ }^{6,84,95,98,168}$, fatores ligados ao gênero, susceptibilidade individual $^{43,129,136}$, uso de anticoncepcionais, dentre outros fatores. O mesmo ocorre quanto à perda de tecido ósseo ${ }^{132}$. Contudo estes fatores responsáveis pela reabsorção radicular não apresentam evidências clínicas que os comprovem.

Alguns trabalhos foram realizados em diferentes épocas com o intuito de esclarecer essas persistentes dúvidas. Em geral os artigos usavam expressões como afirmam, opinam, consideram, relatam, descrevem, mas não apresentam evidências, resultados e comprovação fundamentados em um trabalho com dados que demonstrem uma coerência na interpretação dos mesmos. Infelizmente, esses trabalhos pecam em relação à metodologia e análise dos resultados encontrados ${ }^{17,39,130}$.

PHILLIPS ${ }^{179}$, em 1955, criticou a afirmação de que o envolvimento dos fatores metabólicos seriam os responsáveis pela reabsorção radicular baseado na insuficiência e inconsistência dos registros publicados até aquele momento.

Um dos trabalhos mais citados na literatura sobre o envolvimento sistêmico e a hereditariedade na etiopatogenia das reabsorções dentárias foi publicado em 1975 por NEWMAN ${ }^{167}$. Quanto à hereditariedade, poucas famílias foram observadas e havia muita heterogeneidade genética e etiológica não permitindo conclusões seguras e definitivas a respeito de sua participação na etiopatogenia das reabsorções dentárias, como admitiu o próprio autor. No texto do trabalho, ao interpretar os resultados das famílias examinadas, ressaltava sempre a palavra "possíveis", havendo também limitações da metodologia e ao tamanho da amostra. Na análise de sua casuística, o autor não conseguiu estabelecer qualquer relação com fatores sistêmicos, especialmente entre endocrinopatias e casos de reabsorções dentárias, destacando como exemplos o hipotireoidismo e o hipertireoidismo.

Da mesma forma, ROSENBERG; GURALNICK ${ }^{194}$ examinaram, em 1962, 220 pacientes com hiperparatireoidismo; 116 tiveram examinados seus 
maxilares e realizadas radiografias periapicais. Em 60\% dos pacientes observou-se perda da lâmina dura e em nenhum dos casos foram diagnosticadas reabsorções dentárias.

CHO; LIN; GARANT ${ }^{52}$ em 1991 verificaram que as células que recobrem a superfície radicular (cementoblastos) não apresentam receptores numericamente suficientes para os mediadores químicos do turnover ósseo. São células "surdas" às ordens de remodelação proferidas pelos hormônios reguladores do metabolismo ósseo, especialmente para o paratormônio. Pode então o processo estar ocorrendo nas regiões adjacentes a essa camada de células, porém elas não são afetadas pelo processo.

Em sua tese de mestrado em 1995, PEREIRA ${ }^{178}$ observou que na gestação ocorrem modificações relevantes, como a presença de novos hormônios e a elevação da concentração de outros, como o estrogênio que possui influência sobre o metabolismo ósseo, atingindo níveis muito altos e promovendo modificações no organismo da gestante. Em relação às usuárias de anticoncepcionais foram observadas alterações hormonais durante o ciclo reprodutivo. O resultado de sua pesquisa apontou a inexistência de interferências do uso de anticoncepcionais e da gravidez, na remodelação óssea periodontal durante a movimentação dentária induzida, bem como não predispõem os dentes ao fenômeno da reabsorção.

CAPELOZZA; SILVA FILHO ${ }^{47}$, em 1998, afirmaram que os fatores etiológicos da reabsorção se classificam em gerais, como a hereditariedade, gênero, idade e estado de saúde; mas também locais como tipo de má oclusão, hábitos, traumatismo prévio, estágio de desenvolvimento radicular, forma radicular e saúde bucal; e mecânicos, como a magnitude da força ortodôntica, intervalo de sua aplicação, tipo e duração dessa força.

TYROVOLA; SPYROPOULOS ${ }^{235}$, 2001, publicaram uma revisão sobre os efeitos de drogas e dos fatores sistêmicos no tratamento ortodôntico destacando o paratormônio, a vitamina $D$, os estrógenos e a calcitonina, pois acreditavam na possibilidade de influenciarem na velocidade da movimentação dentária induzida. Concluíram ocorrer ação sobre os processos reabsortivos no tecido ósseo, e não sobre as raízes, afetando dessa forma a movimentação dentária indiretamente. 
FRANCISCHONE ${ }^{80}$, em 2002, avaliou por meio de radiografias os dentes e ossos maxilares de 81 pacientes que apresentavam algum tipo de endocrinopatia. Seus resultados demonstraram que os dentes e suas raízes não sofreram qualquer alteração devido aos distúrbios endócrinos. Evidenciou então que os dentes e suas raízes não estão envolvidos nos sistemas reguladores do turnover ósseo ou participam do controle dos níveis sangüíneos de cálcio, eliminando a possibilidade da influência de distúrbios endócrinos na etiopatogenia das reabsorções radiculares.

Apesar dos fatores sistêmicos terem sido apontados como responsáveis pela reabsorção radicular, não há evidências clínicas e científicas que comprovem essa afirmação $35,36,55,58-63,80,83$. Dessa forma, eliminou-se a possibilidade da influência de distúrbios endócrinos e sistêmicos na etiopatogenia das reabsorções radiculares, cabendo então a investigação das causas locais.

Quanto aos fatores locais, são citados os processos inflamatórios periapicais $^{145}$, as compressões por cisto e dentes impactados, o trauma oclusa $^{102}$, os hábitos como a onicofagia ${ }^{172}$ e 0 bruxismo ${ }^{170}$, os traumatismos ${ }^{136,141}$, bem como os fatores relacionados ao tratamento ortodôntico $^{45,70,87,109,151,186,201,205,247}$.

\subsubsection{As causas}

As reabsorções em ortodontia ocorrem quando as forças aplicadas sobre a estrutura radicular excedem a resistência e a habilidade reparatória dos tecidos periapicais ${ }^{177}$. Dentre várias outras circunstâncias passíveis de provocar reabsorção dos dentes permanentes, destacam-se os processos inflamatórios periapicais causados por agentes biológicos e produtos bacterianos; os agentes químicos como os produtos de clareação dentária e os agentes físicos, como o calor excessivo, um trauma agudo, a oclusão traumática, o bruxismo, erupções ectópicas, a avulsão e as compressões císticas e dos dentes impactados ${ }^{35,36,58,177}$. 
A justificativa para o fato de alguns pacientes apresentarem reabsorção dentária e outros não seria a presença prévia de reabsorção, os aspectos inerentes à técnica ortodôntica utilizada e as diferenças morfológicas dentária e óssea ${ }^{58,83}$.

\subsubsection{Fatores relacionados ao paciente}

As diferenças na morfologia radicular e o tipo de mecânica empregada podem explicar a ocorrência de reabsorções dentárias em alguns pacientes, enquanto em outros esse fenômeno não ocorre durante a terapia ortodôntica.

Alguns autores ${ }^{53,58,83,119,120,129,130,157,205,206,229}$ já ressaltaram a maior predisposição à reabsorção dentária devido a morfologia radicular, como a forma em pipeta, a dilaceração da raiz e as raízes curtas. Esta preocupação com a morfologia radicular encontra-se descrita desde 1927 por KETCHAM ${ }^{118}$

KJAER $^{120}$ realizou um estudo, em 1995, com o propósito de identificar que características dentárias apresentavam os pacientes que sofreram reabsorções severas no tratamento ortodôntico. Para tanto, selecionou radiografias pré-tratamento de 107 pacientes apresentando um ou mais dentes com uma reabsorção superior a um terço do comprimento radicular, ao final do tratamento. Nos resultados pertinentes ao comprimento radicular, foram encontradas raízes curtas nos incisivos da maioria dos pacientes. Quanto à forma radicular, 39 pacientes evidenciaram raízes estreitas e com forma de pipeta, sendo a maioria em incisivos e pré-molares. Dilacerações foram observadas em 22 pacientes. Concluiu ocorrer forte ligação entre as características morfológicas e a tendência de reabsorção das raízes durante o tratamento.

Buscando determinar os fatores que apresentariam maior risco para o início do processo de reabsorção radicular apical, MIRABELLA; ARTUN ${ }^{157}$, também em 1995, analisaram principalmente a morfologia radicular, o comprimento da raiz, a quantidade de movimento radicular e o tipo de mecânica utilizada. Verificaram que a quantidade de movimento radicular e a 
presença de raízes longas delgadas e curvas aumentam o risco de reabsorção radicular. Também salientaram que o uso de elásticos intermaxilares pode ser um fator de risco para os dentes que suportam os elásticos, apenas, e que existem outros fatores etiológicos impossíveis de serem determinados, como uma variação individual da resposta do organismo às forças ortodônticas e a predisposição genética. Em relação à mecânica empregada, não encontraram correlação significante com a quantidade de intrusão e retração. Segundo os autores, a presença e quantidade de retração por si só não significa maior perda radicular, mas haveria outros fatores envolvidos, como tempo e força utilizados para se realizar o movimento.

Outro estudo analisando o valor da morfologia radicular nas reabsorções é o de THONGUDOMPORN; FREER ${ }^{229}$, de 1998. As anomalias analisadas foram agenesia, impacção, erupção ectópica, invaginacão, dentes conóides, raízes com forma de pipeta ou estreitas, curtas ou arredondadas e taurodontismo. Concluíram que pacientes com um tipo de anomalia ao menos exibiram níveis de reabsorção radicular significantemente mais altos que os pacientes sem qualquer tipo de anomalia morfológica. Além disso, ressaltaram que as raízes curtas ou com forma de pipeta apresentam-se mais predisponentes à reabsorção radicular, e que devem receber maior atenção durante o planejamento do tratamento ortodôntico.

Já para identificar os fatores que pudessem predizer a localização e a severidade das reabsorções radiculares, SAMESHIMA; SINCLAIR ${ }^{205,206}$ em 2001 observaram 868 pacientes com aparelhos ortodônticos fixos do tipo Edgewise utilizando radiografias periapicais de toda a boca. Os resultados mostraram que a reabsorção dentária ocorre principalmente nos dentes anteriores, em especial nos incisivos laterais superiores e em dentes com formas radiculares anormais. sem distinção entre os gêneros e em nenhum momento incluíram as alterações sistêmicas entre os fatores diagnósticos e prognósticos, mas sim uma correlação com os trespasses vertical e horizontal acentuados, devido à exigência de maior torque e movimentação necessários.

FURQUIM ${ }^{83}$, em 2002, pesquisou quais seriam os fatores locais que ocasionariam a morte dos cementoblastos. Verificou que num grupo de pacientes submetidos ao tratamento ortodôntico e com reabsorção dentária 
presente, a morfologia radicular triangular e a morfologia da crista óssea alveolar retangular foram significantemente mais freqüentes que no grupo de pacientes submetidos a tratamento que não apresentavam reabsorção.

Um dos principais fatores a serem analisados para o prognóstico da reabsorção radicular diz respeito à morfologia radicular ${ }^{51,58,120}$. A forma da raíz distribui diferentemente as forças, concentrando mais ou menos a força no ápice ${ }^{53,157,205}$. Devido ao movimento de alavanca gerado, a região apical é a que mais sofre os esforços. Pelo mesmo princípio, as raízes curtas por possuírem menor proporção coroa/raiz sofrem maior força de alavanca, estando sujeitas à maior resultante de forças na região apical. Proporcionalmente, a raíz deveria ter 1,6 do tamanho da coroa, considerada anatomicamente a partir do nível ósseo apresentado na região cervical, e não do limite amelocementário ${ }^{58}$.

Também, os diferentes dentes apresentam tendências de reabsorção distintas. Vários estudos apontam os superiores como sendo mais susceptíveis que os inferiores, principalmente os incisivos $^{1,2,16,29,43,45,47,70,109,115,177,179,226}$. Possuem apenas uma raíz, com formato geralmente cônico e afilado e conduzem a força diretamente ao ápice mais facilmente $e^{53,58,157,205}$.

\subsubsection{Fatores relacionados ao tratamento ortodôntico}

Os incisivos superiores são os mais frequentemente reabsorvidos pois são os dentes mais movimentados durante o tratamento ortodôntico, principalmente nos casos de Classe II com extrações, objeto deste estudo $3,13,44,109,177,205,206$.

Dos movimentos dentários, o de intrusão ${ }^{58,155,177,186}$ e o de retração anterior $^{16,18,35,36,69,97,113,117,150,151,157,203,204,206,212}$ são os que causam maior reabsorção durante o tratamento ortodôntico.

Entretanto, os vários trabalhos que foram executados nem sempre encontraram resultados semelhantes e concordantes. 
Para DESHIELDS ${ }^{70}$, em 1969, não há nenhuma correlação entre o movimento intrusivo dos incisivos centrais superiores com a quantidade de reabsorção da raiz. O estudo foi realizado num grupo de pacientes Classe II, divisão 1, tratados sem extrações, e tanto os incisivos centrais como os laterais apresentaram o mesmo grau médio de reabsorção. Para os movimentos de retração, a correlação foi significante.

Utilizando forças ortodônticas com diferentes magnitudes e duração HARRY; SIMS ${ }^{97}$ observaram, em 1982, que os ápices dentários apresentaram reabsorções de maneiras diversas, entre os pacientes. Também observaram correlação da reabsorção maior com o tempo de aplicação da força e em menor grau também com a intensidade.

LINGE; LINGE ${ }^{136}$, em 1983, não encontraram em sua pesquisa correlação da reabsorção com as quantidades de trespasses horizontal e vertical. Afirmam que o uso de fios retangulares e elásticos intermaxilares aumentam o risco das reabsorções e estas podem se tornar severas o suficiente para comprometer a longevidade do dente e contra-indicar abordagens com técnicas específicas mais lesivas. Sugerem que pacientes que iniciam o tratamento ortodôntico precocemente apresentam um risco diminuto de reabsorções.

O controle do tempo do tratamento é um importante fator a ser considerado, afirmam MCFADDEN et al. ${ }^{150}$, em 1989, principalmente quando se realiza a intrusão dos incisivos superiores. Em relação aos casos com extração, não encontrou diferença estatisticamente significante aos sem extração, mesmo que alguns ainda apresentassem sobremordida acentuada. Justificou seu achado como sendo devido à técnica utilizada nos tratamentos, que foi a de arcos segmentados.

Já KALEY; PHILLIPS ${ }^{115}$ afirmam, em 1991, que os fatores responsáveis pela reabsorção dentária não seria o movimento de intrusão, mas sim a aproximação das raízes com a cortical óssea, e isso seria obtido com o torque lingual de raíz, inclinação dentária e a retração anterior.

Após avaliar casos tratados pelas mecânicas Edgewise e Begg convencionais, BECK; HARRIS ${ }^{16}$ em 1994 afirmam, que quanto maior o 
sobrepasse horizontal, maior a movimentação de retração realizada para a correção e quanto maior o trespasse vertical, maior o movimento de intrusão, gerando em ambos os casos maiores quantidades de reabsorção.

O uso de forças leves durante a intrusão é enfatizado por COSTOPOULOS; NANDA ${ }^{65}$, no ano de 1996, como meio de prevenir os processos de reabsorção. Essa orientação vem ao encontro da proposta por CONSOLARO ${ }^{58}$ em 2002.

Afirmando que a resposta tecidual após um movimento de intrusão depende da espessura do ligamento periodontal e do tipo de osso alveolar que envolve as raízes, REITAN; RYGH ${ }^{187}$, em 1996, atestam também que em tratamentos iniciados em idades precoces, a correção com a mecânica de intrusão pode ocorrer com mais eficiência e menor grau de reabsorções.

No mesmo ano, em uma amostra de 81 pacientes adultos, BAUMRIND; KORN; BOYD ${ }^{14}$ correlacionaram as forças de intrusão com as movimentações dos incisivos superiores e a reabsorção encontrada. Segundo a pesquisa, os movimentos de intrusão, extrusão e protrusão não apresentaram correlação significante com a reabsorção. A falta de associação significante entre a intrusão e a reabsorção contrapõe-se aos resultados de outros estudos, e os autores afirmam ser decorrente de estudos realizados com amostras e metodologias não tão rigorosas. Inclusive, o coeficiente de correlação estatístico com a variável intrusão apresentou até valor negativo, o que significa que mais intrusão ocasionaria menos reabsorção. Em relação à retração a correlação foi altamente significante.

A combinação da intrusão do ápice com o torque lingual de raíz, para PARKER; HARRIS ${ }^{177}$, 1998, é mais importante em termos de seqüelas para as raízes dentárias. A combinação de movimentos explicaria a variação dos níveis de reabsorção encontrados em diferentes indivíduos. Em seu estudo, utilizou 110 adolescentes, com Classe I com extrações de pré-molares, divididos em 3 grupos de acordo com as 3 técnicas de tratamento estudadas (Edgewise convencional, Begg e pré-ajustados prescrição Roth). Avaliaram os incisivos superiores e não encontraram diferenças significantes, no grau de reabsorção, entre as técnicas, tampouco nos movimentos de retração, extrusão e inclinação lingual dos referidos dentes. Convém salientar que a quantidade 
de reabsorção foi avaliado nos incisivos centrais superiores medidos em telerradiografias.

Segundo SAMESHIMA; SINCLAIR ${ }^{205,206}$, em 2001, a mecânica de retração por si só seria a responsável pelo grau de reabsorção encontrado. Em sua pesquisa, não encontraram correlação estatisticamente significante da mesma com os movimentos de intrusão. Já em $2004^{204}$, os autores correlacionam o deslocamento horizontal dos ápices como potencial fator de risco para as reabsorções severas, juntamente com o tempo de tratamento, pressionamento lingual e raízes com anormalidades de forma.

Em 2003 BRIN $^{38}$, estudando radiografias de 138 crianças, publicou sua pesquisa afirmando que, nos tratamentos da Classe II, quanto maior a sobressaliência existente, maior reabsorção apical se pode esperar ao final do tratamento. Nos tratamentos em duas fases encontrou menor grau de reabsorção, pois a movimentação dentária necessária seria menor, bem como o tempo de uso do aparelho fixo.

SHAW; SAMESHIMA; VU ${ }^{214}$ em 2004, utilizando um modelo fotoelástico, mostraram que os movimentos de intrusão causados pela mecânica ortodôntica são os que causam maior pressão no ápice.

Em seu estudo, MALTHA et al. ${ }^{142}$, em 2004, concluíram que quanto maior a extensão do movimento, o tempo de aplicação e a quantidade das forças, maior o índice de reabsorção encontrado. As forças intermitentes causariam 40 a $70 \%$ menos reabsorção que as forças aplicadas continuamente.

\subsubsection{Detecção e avaliação}

É incontestável que a única forma de se avaliar um processo de reabsorção é pela radiografia periapical, conseqüentemente a radiografia panorâmica não é adequada para avaliar as anomalias morfológicas das raízes. SAMESHIMA; ASGARIFAR ${ }^{203}$ em 2001 afirmaram que a classificação da morfologia radicular a partir de radiografias panorâmicas revelou uma diferença significante das radiografias periapicais. As dilacerações radiculares 
e outras formas anormais freqüentemente aparecem com um formato radicular normal nas radiografias panorâmicas e o mesmo não ocorre nas radiografias periapicais ${ }^{42,109,169,203}$. Estas últimas apresentam mais detalhes e os mesmos são mais refinados ${ }^{128,203}$.

A telerradiografia, segundo LEACH; IRELAND; WHAITES ${ }^{128}$, em 2001, é uma modalidade de avaliação fiel apenas para os incisivos superiores, em especial os centrais. No entanto, torna-se importante considerar o fator de magnificação inerente à técnica, principalmente quando as radiografias, inicial e final, são obtidas em aparelhos diferentes. Afirma também a dificuldade em se avaliar os incisivos laterais e caninos, visto as sobreposições que ocorrem em maior quantidade, e também a possibilidade de se sobreporem às raízes dos incisivos centrais dificultando a análise dos mesmos, que já apresentam sobreposição com o seu homólogo.

Entre todas as técnicas radiográficas, a periapical do paralelismo é a mais fiel, por minimizar consideravelmente o risco de distorções e ampliações, do que a da bissetriz e outras ${ }^{7,22,86,127,153,179}$.

Por todos os fatores mencionados, idealizou-se o estudo sobre a reabsorção que ocorre nos incisivos quando há existência de um trespasse horizontal proeminente tratado com extrações e retração, e à ele é adicionado a mecânica de intrusão com acentuação e reversão da curva de Spee, para a correção da sobremordida profunda. Avalia-se assim se ocorre alguma diferença na quantidade de reabsorção quantificando a responsabilidade da intrusão na quantidade de reabsorção encontrada ao final do tratamento, utilizando-se uma amostra que elimine o máximo possível de variáveis que possam interferir nos resultados. Também correlações com o tempo de tratamento e algumas modificações cefalométricas dentárias impostas pelo tratamento serão realizadas, bem como avaliar a incidência nos incisivos centrais e laterais. 
Proposição 


\section{3 - PROPOSIÇÃO}

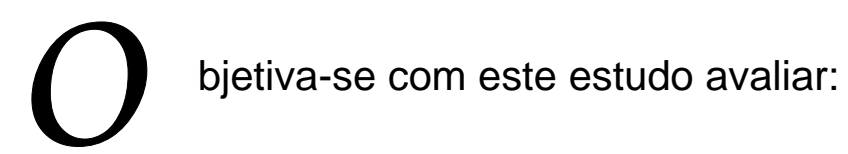

1. se o grau de reabsorção radicular é semelhante ou é agravado nos tratamentos realizados com o movimento conjugado de intrusão e retração, comparando com casos tratados apenas com retração para correção da sobressaliência, avaliando assim a participação da mecânica intrusiva no grau de reabsorção;

2. a severidade e distribuição da reabsorção encontrada em ambas as formas de tratamento;

3. a existência de correlação com:

a. o tempo de tratamento;

b. com a quantidade de sobremordida e sobressaliência iniciais;

c. com as quantidades de correção dos trespasses causadas pelo tratamento e de movimentação dos ápices nos sentidos vertical e horizontal, bem como a inclinação dos dentes;

4. a existência de diferentes graus de reabsorção entre os incisivos centrais e laterais em ambos os grupos;

5. Determinar se a conjugação da mecânica de intrusão à de retração representa um fator clinicamente relevante na predição da reabsorção radicular. 


\section{Material \\ e Métodos}




\section{4 - MATERIAL E MÉTODOS}

\subsection{Material}

$4 \begin{aligned} & \text { reabsorção foi avaliada em radiografias periapicais de } \\ & \text { pacientes tratados com extração de pré-molares e retração }\end{aligned}$ anterior para correção da sobressaliência acentuada, e mecânica de intrusão para a correção da sobremordida profunda, utilizando-se a técnica Edgewise Simplificada. Comparou-se com um grupo controle ${ }^{18}$ apresentando as mesmas características de sobressaliência acentuada, porém sem sobremordida profunda, com extrações e retração para o seu tratamento, sem mecânica de intrusão. Foram selecionadas 56 documentações ortodônticas dentre as disponíveis nos arquivos da disciplina de Ortodontia, da Faculdade de Odontologia de Bauru, da Universidade de São Paulo, em caráter retrospectivo, de casos tratados pelos alunos da Pós-graduação Latu Sensu e Strictu Sensu dessa Faculdade, que correspondessem aos critérios necessários para a seleção dessa amostra.

\subsubsection{Critérios de seleção da amostra}

Consideraram-se para a amostra apenas os pacientes que possuíssem uma documentação do tratamento completa, dispondo da ficha clínica, dos modelos, das telerradiografias e radiografias periapicais, da região dos incisivos superiores, pré e pós-tratamento, em excelentes condições.

Com relação aos tipos de más oclusões, selecionaram-se inicialmente, os pacientes que apresentaram trespasses vertical e horizontal positivos de no mínimo $4 \mathrm{~mm}$, avaliados clinicamente pelo modelo, e que realizaram tratamento ortodôntico com arcos de nivelamento incorporando acentuação e reversão da Curva de Spee e também com extrações 
dentárias de pré-molares para a correção do trespasse horizontal aumentado, sendo denominado de Grupo 1. Para o grupo controle ${ }^{18}$, foram selecionados os modelos que apresentaram um trespasse vertical normal, com até 2/3 de recobrimento da coroa do incisivo inferior e um trespasse horizontal aumentado também de no mínimo $4 \mathrm{~mm}$, submetidos ao tratamento ortodôntico pela mesma técnica e também com extração de prémolares, porém sem ação de nenhum tipo de mecânica intrusiva, sendo denominado de Grupo $2^{18}$.

Foram excluídos os pacientes cujos dentes apresentaram tratamento endodôntico bem como reabsorções prévias ao tratamento ortodôntico, histórico de traumatismos, desenvolvimento incompleto dos ápices radiculares, agenesias, supranumerários e raízes mal formadas diagnosticados nas radiografias pré-tratamento foram excluídos, assim como os pacientes cuja documentação ortodôntica inicial apresentava-se incompleta. Também foram eliminadas as radiografias que evidenciaram distorções ou falta de nitidez. Outras exclusões ocorreram ao se constatar tracionamentos de dentes anteriores impactados, tratamentos ortodônticos e cirúrgicos prévios e pacientes que solicitaram a remoção precoce do aparelho antes da sua finalização completa.

Não houve distinção de raça, gênero e condições sócioeconômicas ou culturais. Porém, com relação à gravidade da má oclusão na região anterior, preocupou-se em estabelecer uma proporção semelhante entre todas as características nos dois grupos e o mais divergente possível na variável a ser analisada, neste caso a quantidade de sobremordida profunda.

Para quantificação da reabsorção, foram examinadas as radiografias periapicais, pré e pós-tratamento, dos incisivos superiores. A restrição a esses dentes procede pela quantidade de casos tratados com extrações no arco superior consideravelmente maior do que no arco inferior e por ser a forma de tratamento mais utilizada na maioria dos casos ortodônticos mais discrepantes, de Classes I e II de Angle. Também, a quantidade de reabsorção apical durante a movimentação ortodôntica com 
extrações apresenta-se consideravelmente maior, e a maioria dos autores concorda que são esses os dentes que reabsorvem com mais freqüência e intensidade durante o tratamento ortodôntico ${ }^{4,43,45,47,70,80,83,109,115,179,226}$.

Da mesma forma, pode-se afirmar que os fenômenos que ocorrem nas células e componentes da estrutura radicular dos dentes submetidos à este tipo e quantidade de movimentação, podem ser aplicados a qualquer outro dente que apresente características radiculares semelhantes que sejam submetidos à esses mesmos tipos de movimentos, e que apresentem esse mesmo grupo de características.

\subsubsection{Características da amostra}

Considerando-se os critérios de seleção, a amostra foi composta por 56 documentações divididas em dois grupos distintos, de acordo com a presença ou não de trespasse vertical acentuado, tratados todos com extrações, apresentando as seguintes características em cada grupo:

Grupo 1 (Com sobressaliência e sobremordida acentuadas em que foram realizadas extrações, retração e intrusão): composto por 28 documentações de pacientes com sobremordida e sobressaliência acentuadas, que no início do tratamento, apresentaram uma média de idade de 13,41 \pm 2,38 anos (mínimo de 9,42 e máximo de 21,5 anos), com média de trespasse vertical de 4,78 \pm 1,18 mm (mínimo de 3,5 e máximo de $8,7 \mathrm{~mm}$ ) e horizontal de 6,48 $\pm 2,52 \mathrm{~mm}$ (mínimo de 3,2 e máximo de 12,8mm). O tempo de tratamento médio foi de 27,95 meses. Todos os pacientes apresentavam Classes II, por possuírem as características de sobressaliência e sobremordida mais severas, sendo 12 do gênero feminino e 16 do masculino. Em todos foram utilizadas a mecânica intrusiva com o uso de arcos de nivelamento com acentuação e reversão da Curva de Spee, no intuito de corrigir a sobremordida, e de retração, após a extração 
dos primeiros pré-molares, para corrigir a sobressaliência acentuada presente.

Grupo $2^{18}$ (Com sobressaliência acentuada apenas, com extrações, retração e sem intrusão): Composto por 28 documentações de pacientes com trespasse horizontal acentuado que, no início do tratamento apresentaram uma média de idade de 13,27 \pm 1,85 anos (mínimo de 11,16 e máximo de 19,33 anos), com média de trespasse vertical de 1,12 \pm 0,97 mm (mínimo de 0,1 e máximo de 3,8 mm) e horizontal de 5,67 \pm 2,73 mm (mínimo de 2,9 e máximo de 14,3). O tempo de tratamento médio foi de 29,43 meses. Destes pacientes, 14 apresentavam Classes I e 14 Classes II, sendo 12 do gênero feminino e 16 do masculino. Nenhum foi submetido à mecânica intrusiva, na região dos incisivos, mas apenas de retração, para o fechamento dos espaços das extrações.

Em todos os grupos, a técnica ortodôntica aplicada foi a Edgewise simplificada, que se caracteriza pelo uso de braquetes com ranhuras de 0.022" x 0.028" associado a um arco extrabucal, como ancoragem dos molares superiores, quando necessário. A seqüência de arcos, na maioria dos casos, iniciou-se com um fio twist-flex de 0.015" ou nitinol de 0.016", seguido por arcos com fios de aço inoxidável de 0.016", 0.018", $0.020 "$ e finalmente $0.021 "$ x 0.025". A sobremordida profunda foi corrigida por meio de arcos de nivelamento de aço inoxidável com curvas reversa e acentuada e, nos casos com trespasse vertical normal, mantiveram uma suave acentuação e reversão dos arcos, em todos os casos, para que não extruíssem durante a mecânica de fechamento de espaços. 


\subsection{Métodos}

\subsubsection{Avaliação das Radiografias Periapicais}

As radiografias foram obtidas em vários centros de documentação ortodôntica e em épocas diferentes (pré e pós tratamento), portanto, realizadas em aparelhos e por operadores diferentes. Variações também podem ter ocorrido quanto à forma de processamento das radiografias, à técnica radiográfica e ao tipo e marca dos filmes radiográficos. Desse modo, tornou-se difícil uma avaliação metodológica por medição quantitativa do tamanho radicular, de forma comparativamente direta pois, se assim fosse, poder-se-ia incorrer em erros. Assim, de forma semelhante à outros estudos ${ }^{16,18,43,51,94,96,109,143}$, optou-se pela utilização do método e classificação de MALMGREN et al. ${ }^{141}$, modificada por JANSON et al. $^{109}$ para avaliar a severidade da reabsorção apical, distribuindo-a em 5 graus (Figura 1) que quantificam a reabsorção radicular por meio de escores, descritos a seguir:

- Grau 0 - ausência de reabsorção radicular (Fig.2);

- Grau 1 - reabsorção leve, observando-se apenas contorno irregular, com raiz apresentando o seu comprimento normal (Fig.3);

- Grau 2 - reabsorção moderada, com pequena perda radicular e 0 ápice exibindo um contorno quase retilíneo (Fig.4);

- Grau 3 - reabsorção acentuada, com grande perda radicular, atingindo quase $1 / 3$ do seu comprimento (Fig.5);

- Grau 4 - reabsorção extrema, com perda maior que $1 / 3$ do comprimento radicular (Fig.6).

As radiografias periapicais pré-tratamento foram utilizadas como parâmetro para obtenção do grau de severidade da reabsorção radicular ocorrida, comparando-as com as radiografias pós-tratamento, em ambos os grupos. 


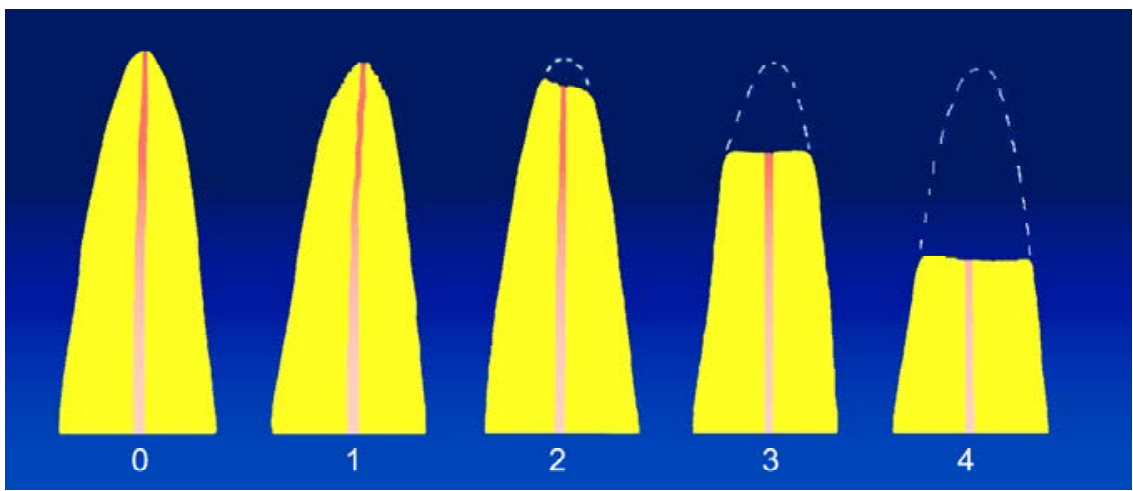

FIGURA 1 - Classificação dos graus de reabsorção, segundo MALMGREN et al. ${ }^{141}$.

Utilizando-se esse método de quantificação modificado, foram obtidos para cada paciente quatro escores referentes à avaliação do grau de reabsorção de cada um dos incisivos superiores, perfazendo-se um total de 112 escores no grupo 1 e 112 escores no grupo 2.

As radiografias periapicais foram escaneadas em um scanner de slides 35mm da Polaroid, o SprintScan 35 Plus $^{1}$, com uma resolução de 675 dots per inch (dpi) e escala de proporção de 1:1 ou 100\%. As imagens foram padronizadas (Fig.7 e 8) e analisadas no programa Adobe Photoshop 8.0 $\mathrm{CS}^{2}$, ampliando as mesmas em até 7 vezes sem perda de qualidade ${ }^{51,56,83}$. As avaliações foram realizadas em um ambiente de penumbra, sem identificação do grupo ao qual a radiografia procedesse.
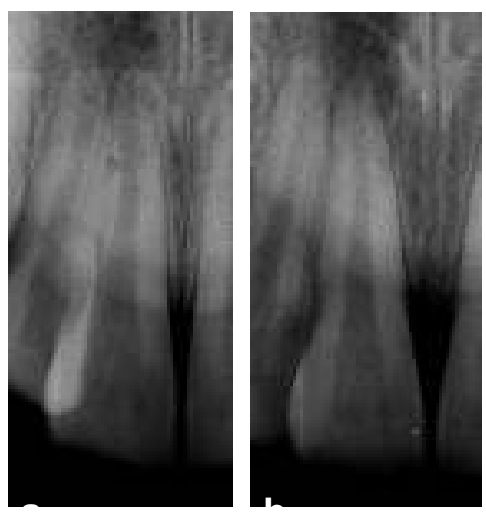

FIGURA 2 - Radiografias periapicais inicial (a) e final (b) de incisivo central com grau 0 de reabsorção.

${ }^{\perp}$ Version 2.7.2, Polaroid Corporation. ${ }^{2}$ Adobe Systems Incorporated. San Jose, Ca, USA.
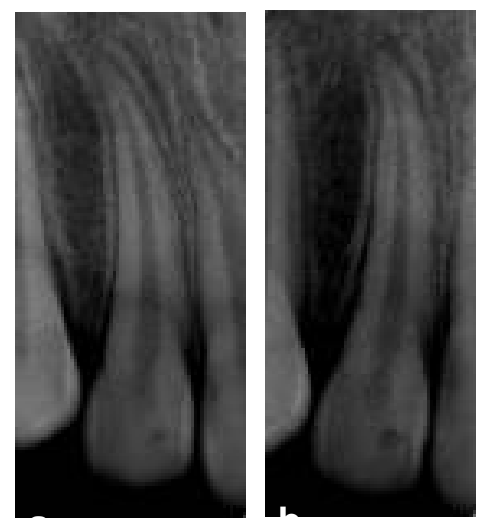

FIGURA 3 - Radiografias periapicais inicial (a) e final (b) de incisivo lateral com grau 1 de reabsorção. 

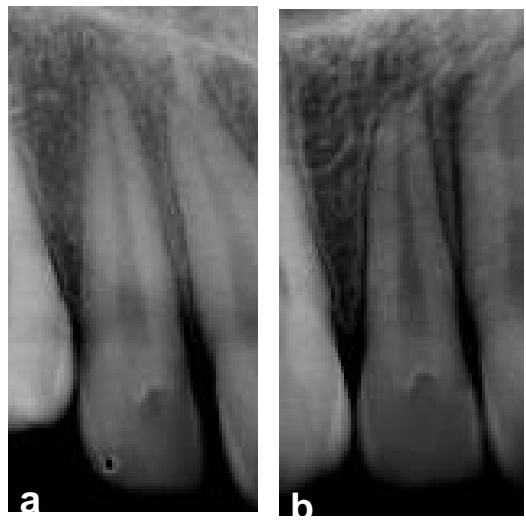

FIGURA 4 - Radiografias periapicais inicial (a) e final (b) de incisivo lateral com grau 2 de reabsorção.
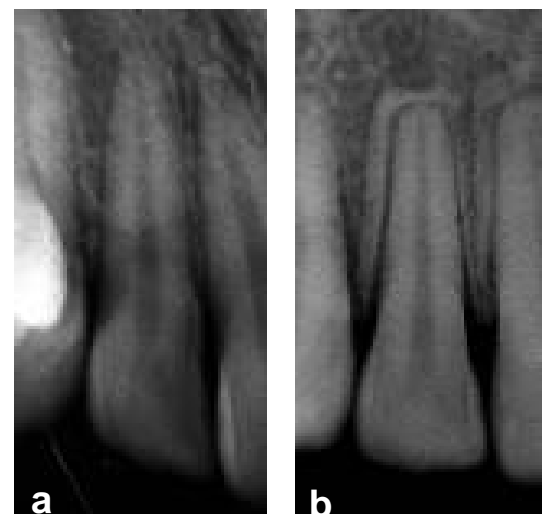

FIGURA 5 - Radiografias periapicais inicial (a) e final (b) de incisivo lateral com grau 3 de reabsorção.

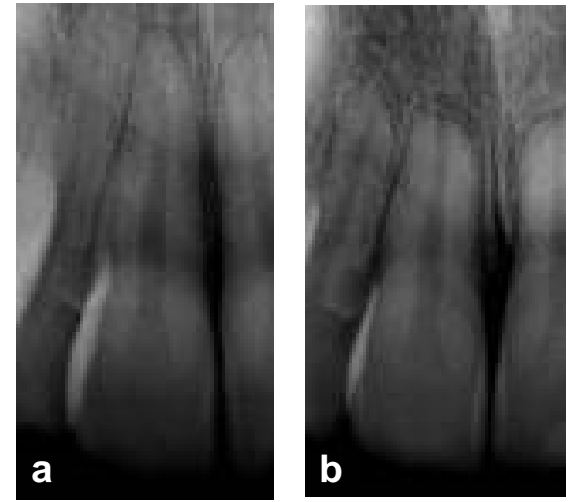

FIGURA 6 - Radiografias periapicais inicial (a) e final (b) de incisivo central com grau 4 de reabsorção.

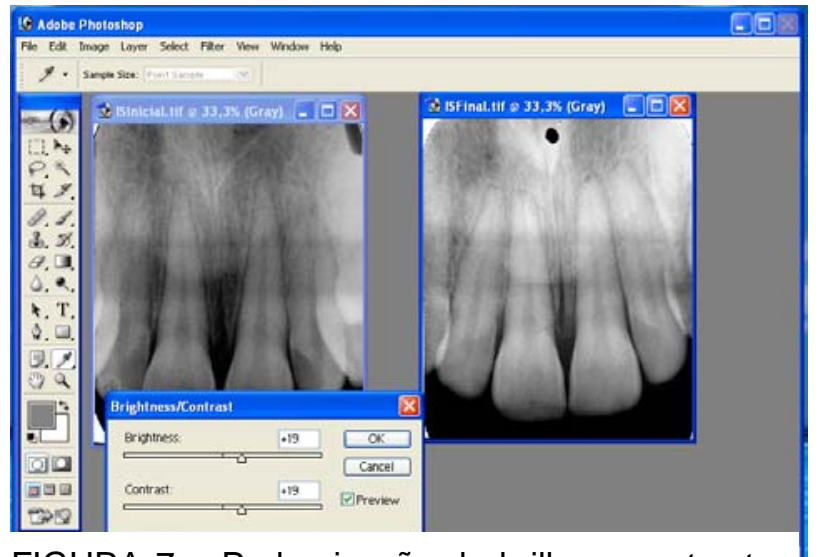

FIGURA 7 - Padronização do brilho e contraste entre as radiografias iniciais e finais.

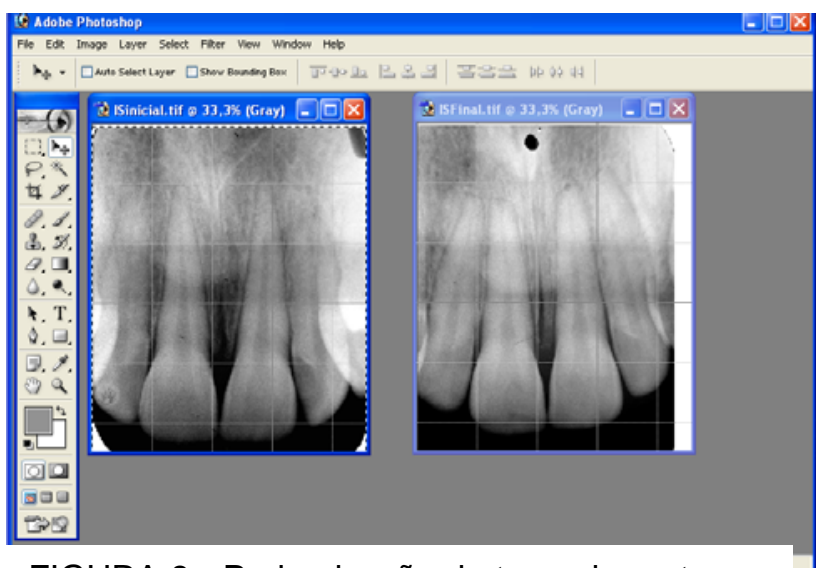

FIGURA 8 - Padronização do tamanho entre as radiografias iniciais e finais. 


\subsubsection{Avaliação cefalométrica}

Para avaliação do grau de movimentação dos incisivos centrais, após a correção da sobressaliência, tanto no sentido vertical como horizontal, foram utilizadas as radiografias em norma lateral, pré e póstratamento, dos 56 pacientes, utilizando-se algumas variáveis como aplicadas em outros estudos ${ }^{16,18,51,177}$. As variáveis investigadas foram as alterações ocorridas na inclinação dos incisivos e o deslocamento que os ápices sofreram tanto nos sentidos vertical como horizontal, bem como as ocorridas nas relações entre as bordas incisais.

Para isso realizaram-se os traçados cefalométricos e as demarcações dos pontos, manualmente, em papel de acetato ultraphan, de 0,07mm de espessura, e tamanho de 17,5 x 17,5 centímetros, sobre um negatoscópio, com auxílio de uma máscara, em uma sala escurecida. Posteriormente, esses pontos foram digitalizados por meio de uma mesa digitalizadora Numonics A-30TL. $F^{3}$, conectada a um microcomputador com processador AMD K-6 II 500MHz, para obtenção das grandezas cefalométricas.

Os traçados e a digitalizações dos pontos foram realizados pelo examinador, utilizando-se o padrão Ortho Lateral do Programa Dentofacial Planner, versão $7.02^{4}$, para a realização das medições. Como as radiografias foram tomadas em diferentes centros de documentação, tomouse o cuidado de indicar o fator de magnificação, permitindo a sua correção pelo próprio programa, que variou conforme o centro de documentação de 6.0 a $9.8 \%$.

- FOB-USP - 6.0 (até 1994) ou 9.8 (a partir de 1995);

- SDO - 9.8;

- Ortodiagnosis - 9.8;

- Cebeo - 9.8;

- CDB - 6.0;

- Serdoc-7.94.

${ }^{3}$ Numonics Corporation, Montgomeryville, PA, EUA.

${ }^{4}$ Dentofacial Planner Software Inc., Toronto, Ontário, Canadá. 
Material e Métodos

47

4.2.2.1 Desenho anatômico

As delimitações das estruturas dentoesqueléticas utilizadas no desenho anatômico seguiram as orientações sugeridas por KROGMAN; SASSOUNI ${ }^{123}$. Durante o traçado cefalométrico, sempre que estruturas bilaterais apresentaram imagens duplas, sua média foi considerada. O traçado cefalométrico foi constituído pelo desenho das seguintes estruturas (figura 9):

- Contorno da sela túrcica;

- Perfil do osso frontal e dos ossos nasais;

- Contorno da cavidade orbitária;

- Meato acústico externo;

- Maxila;

- Mandíbula;

- Incisivos centrais superiores e inferiores;

- Primeiros molares e segundos pré-molares superiores e inferiores;

- Contorno do perfil tegumentar.

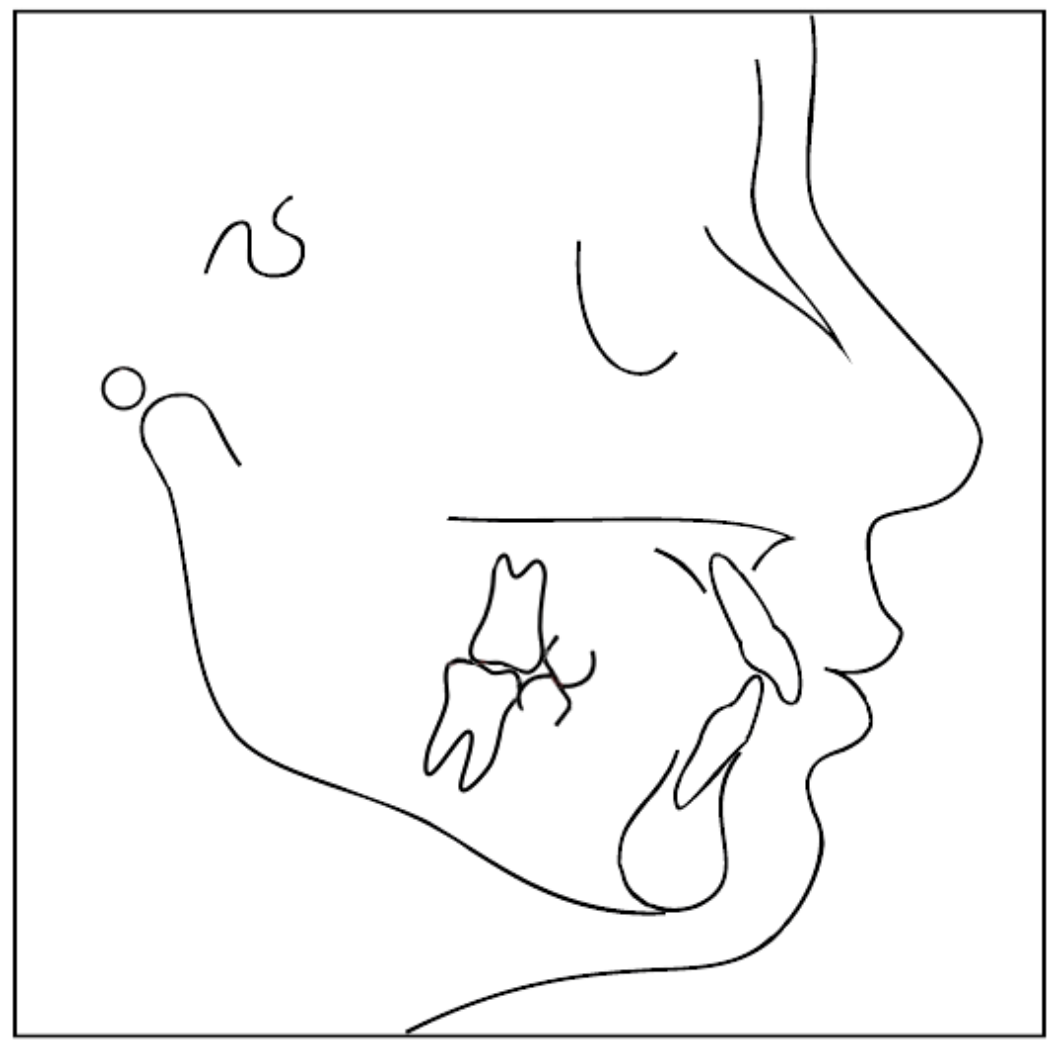

FIGURA 9 - Traçado anatômico 
4.2.2.2 Demarcação dos pontos cefalométricos

A demarcação dos pontos cefalométricos foi executada segundo as definições de SASSOUNI ${ }^{210}$, DOWNS ${ }^{72}$, RIEDEL $^{193}$, MCNAMARA JR $^{152}$, STEINER ${ }^{222}$ e RICKETTS ${ }^{192}$ (figura 10):

- S (Sela Túrcica) - ponto médio da concavidade óssea da sela túrcica;

- N (Násio) - ponto mais anterior da sutura frontonasal;

- ENA (Espinha Nasa Anterior) - ponto mais anterior do assoalho da fossa nasal;

- ENP (Espinha Nasal Posterior) - ponto mais posterior do assoalho da fossa nasal;

- A (Subespinhal) - ponto mais profundo da concavidade do contorno anterior da maxila, determinada girando-se uma régua centrada no ponto $\mathrm{N}$ até a superfície mais posterior da concavidade anterior da maxila;

- B (Supramentoniano) - ponto mais profundo da concavidade da sínfise mentoniana, determinada girando-se uma régua centrada no ponto $\mathrm{N}$ até a superfície mais posterior da concavidade anterior da mandíbula;

- P (Pogônio) - ponto mais anterior da eminência mentoniana, determinado com o auxílio de uma régua centrada no ponto $\mathrm{N}$ até a superfície mais anterior do mento;

- Go (Gônio) - representa o ponto mais póstero-inferior do contorno do ângulo goníaco, determinado pela bissetriz do ângulo formado pelas tangentes às bordas posterior e inferior da mandíbula;

- Me (Mentoniano) - ponto mais inferior da sínfise mentoniana;

- Gn (Gnátio) - representa o ponto mais ântero-inferior do contorno do mento, determinado pela bissetriz do ângulo formado pelo plano mandibular (GoMe) e pela linha NP;

- Po (Pório anatômico) - ponto mais superior do contorno do conduto auditivo externo;

- Or (Orbitário) - ponto mais inferior do contorno da margem da órbita;

- BIS (Borda Incisal do Incisivo Superior) - ponto mais inferior da borda incisal do incisivo central superior; 
- AIS (Ápice do Incisivo Superior) - ponto mais superior do ápice radicular do incisivo central superior;

- BII (Borda Incisal do Incisivo Inferior) - ponto mais inferior da borda incisal do incisivo central inferior;

- IDOM (intercuspidação disto-oclusal molar) - ponto médio da intercuspidação das cúspides distais dos primeiros molares;

- I2PM (intercuspidação dos segundos pré-molares) - ponto médio da intercuspidação das cúspides vestibulares dos segundos pré-molares.

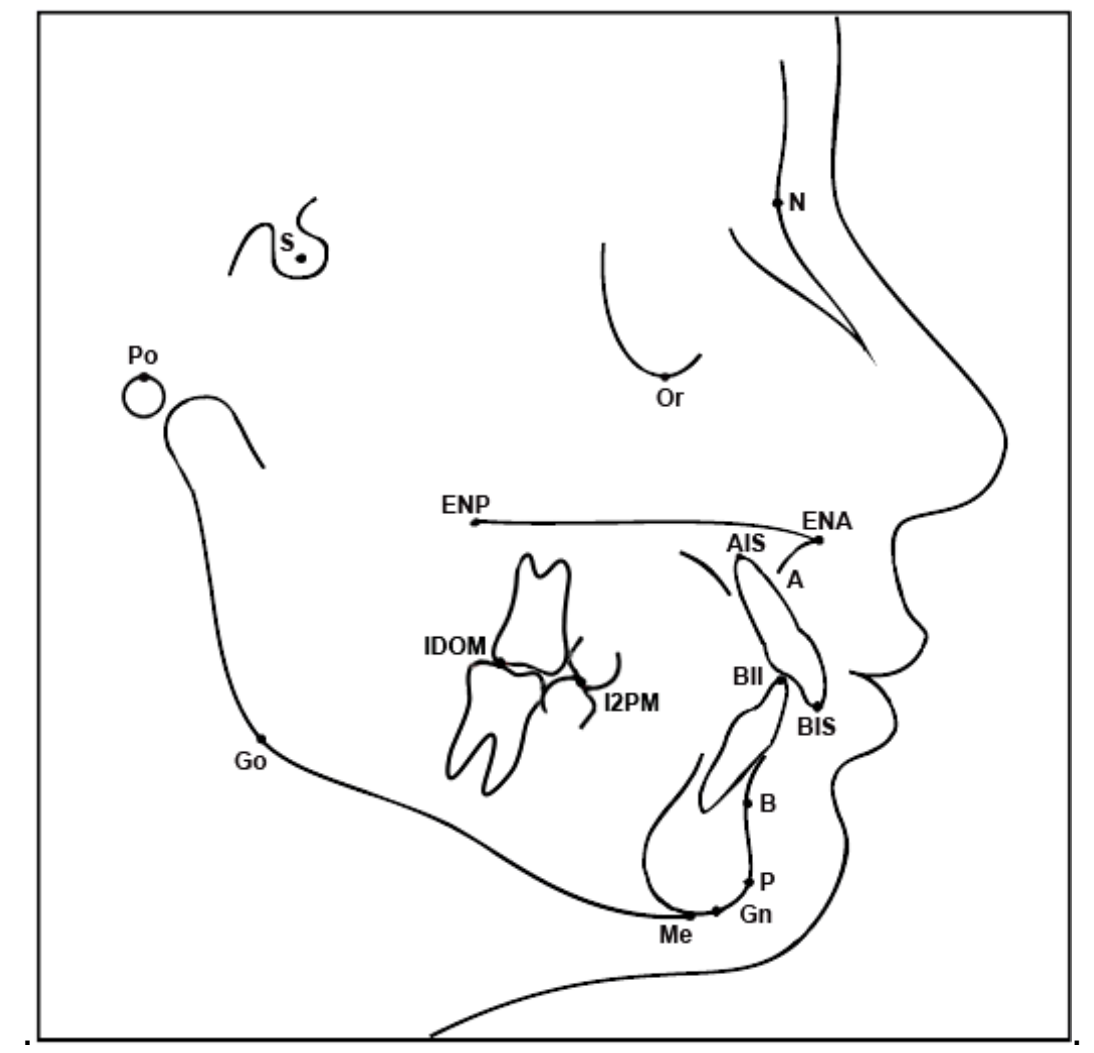

FIGURA 10- Pontos cefalométricos utilizados

\subsubsection{Planos e linhas de referência}

As linhas e planos utilizados serão os seguintes (figura 11):

1. Plano palatino - passa pelos pontos ENA e ENP;

2. Linha longo eixo do incisivo superior - passa pelos pontos BIS e AIS;

3. Linha ENAPerp - linha perpendicular ao plano palatino, passando pelo ponto ENA;

4. Plano Oclusal Funcional (Po) - linha que passa entre o contato oclusal distal dos molares ao contato entre os pré-molares. 


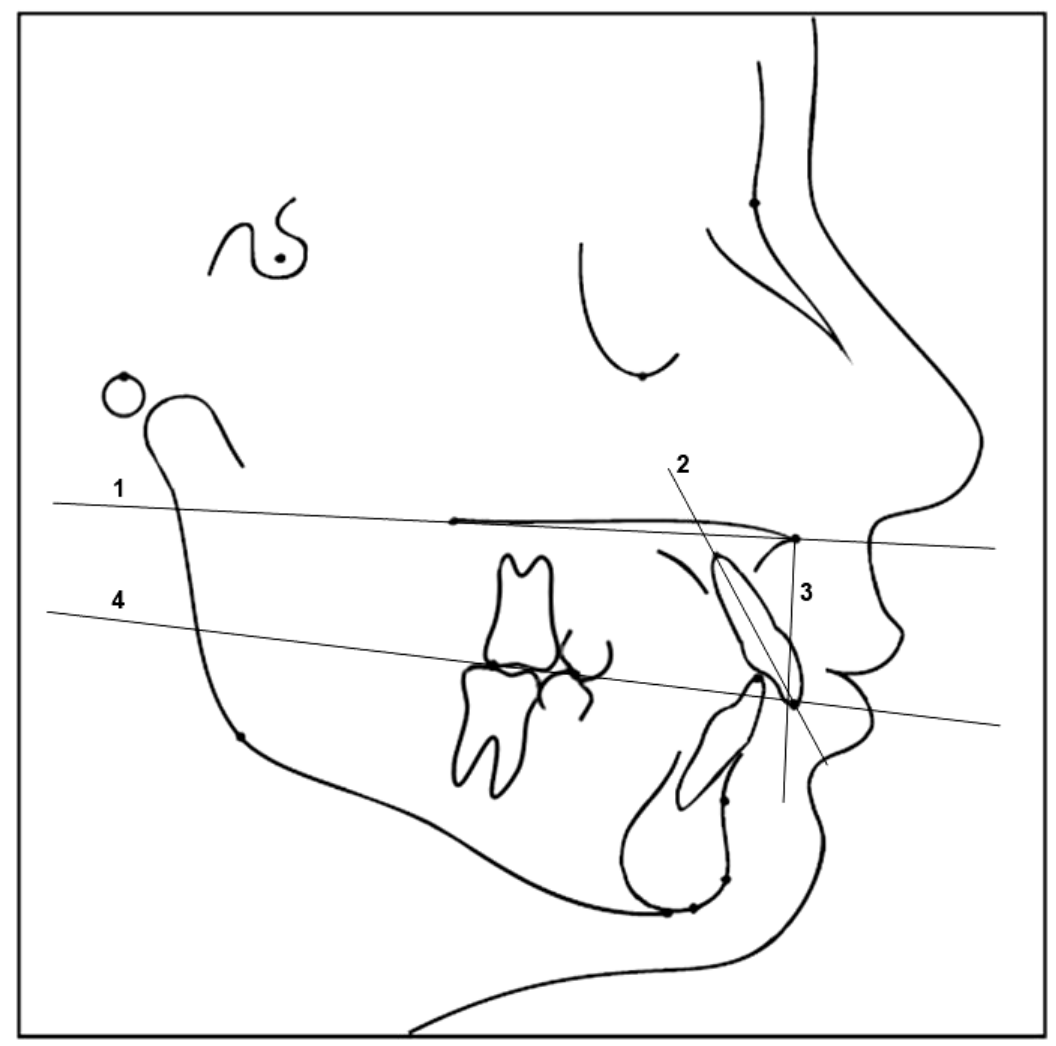

FIGURA 11 - Linhas e planos de referência

\subsubsection{Grandezas cefalométricas}

As grandezas utilizadas foram (figura 12):

1. Trespasse vertical (sobremordida) - distância entre as bordas incisais dos incisivos centrais superiores e inferiores medida perpendicularmente ao plano oclusal funcional;

2. Trespasse horizontal (sobressaliência) - distância entre as bordas incisais dos incisivos centrais superiores e inferiores medida paralelamente ao plano palatino;

3. 1.PP - ângulo formado pela linha longo eixo do incisivo superior e o plano palatino;

4. AIS-PP - distância do ápice do incisivo superior ao plano palatino, medida perpendicularmente a este plano;

5. AIS-ENAperp - distância do ápice do incisivo superior à linha ENAperp, medida perpendicularmente a esta linha; 
Material e Métodos

51
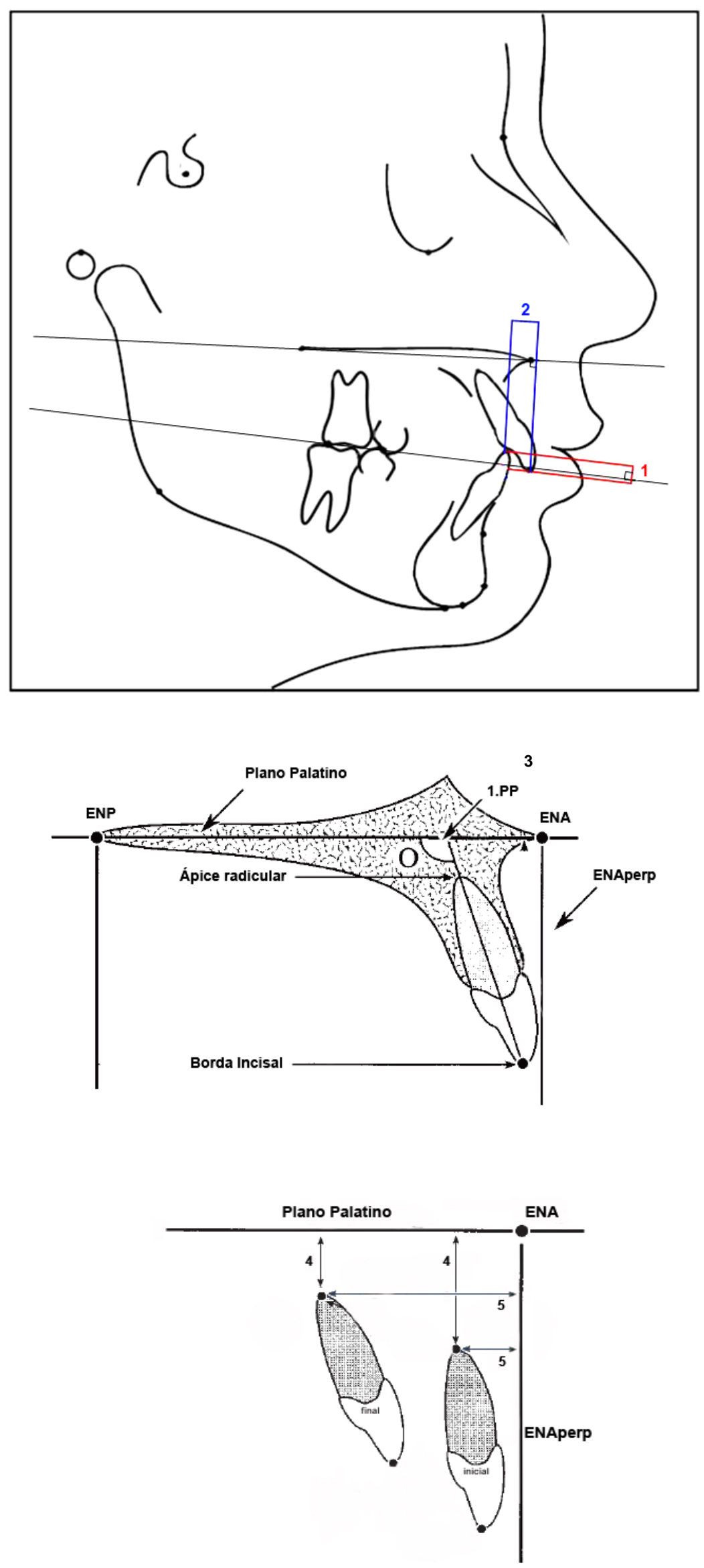
Figura 12- Grandezas Cefalométricas

Após a obtenção de todas as medidas cefalométricas, os grupos foram comparados a partir das variações ocorridas naquelas medidas durante o tratamento (fase final T2 - inicial T1). Para melhor entendimento, convencionou-se que os movimentos verticais de intrusão do ápice sejam representados numericamente por sinal negativo (-), e de extrusão positivo $(+)$. Para os movimentos horizontais, o sinal positivo (+) designa o deslocamento para palatino e o negativo (-) para vestibular.

\subsection{Análise Estatística}

\subsubsection{Erro do método e Concordância Inter-examinadores}

Para verificar a confiabilidade dos resultados, foram realizadas novamente as medições de 30 pacientes, selecionados aleatoriamente, sendo 15 de cada grupo, após um intervalo de 30 dias. Os escores obtidos após a avaliação do grau de reabsorção radicular dos incisivos, nas radiografias periapicais, foram analisados pelo teste de concordância kappa ponderado $^{78,126}$. Para as medidas cefalométricas, aplicou-se o teste "t" para variáveis dependentes, de acordo com HOUSTON ${ }^{106}$, para obtenção do erro sistemático. A aplicação da fórmula $\mathrm{Se}^{2}=\Sigma \mathrm{d}^{2} / 2 \mathrm{n}$, proposta por DAHLBERG ${ }^{67}$, demonstra a variação média entre a primeira e a segunda medição, verificando o erro casual.

\subsubsection{Análise estatística entre grupos e variáveis}

- $\quad$ A avaliação da compatibilidade entre os grupos quanto à idade inicial, tempo de tratamento e quantidade inicial de sobressaliências vertical e horizontal foi realizada por meio do teste "t" independente. 
- Para verificar a compatibilidade entre os grupos quanto ao gênero, aplicou-se o teste qui-quadrado.

- A quantidade de reabsorção foi comparada entre os grupos por meio do teste não-paramétrico Mann-Whitney, utilizando-se a média de reabsorção dos 4 incisivos de cada paciente.

- $\quad$ Em seguida, uma análise descritiva foi realizada para verificar a distribuição percentual do total de dentes avaliados, considerando o grau de reabsorção presente ao final do tratamento.

- Com relação às variáveis cefalométricas, comparou-se as alterações ocorridas durante o tratamento ortodôntico entre os 2 grupos por meio do teste "t" independente. Para a aplicação do teste "t", é necessário que as variáveis apresentem uma distribuição normal, sendo então avaliadas previamente pelo teste Kolmogorov-Smirnov, individualmente.

- A quantidade dos trespasses iniciais, de correção da sobremordida e da sobressaliência, o tempo de tratamento, a quantidade de deslocamentos vertical e horizontal dos ápices dos incisivos superiores foram correlacionados com o grau de reabsorção utilizando-se o coeficiente de correlação de Spearman.

- $\quad$ grau de reabsorção foi comparado entre os incisivos centrais e laterais em ambos os grupos. Para isso, utilizou-se o teste de Wilcoxon, sendo considerada a média dos escores.

- Essas análises estatísticas foram realizadas no programa de computador Statistica for Windows $6.0^{5}$. Os resultados foram considerados estatisticamente significantes para $\mathrm{p}<0,05$.

${ }^{5}$ STATISTICA for Windows. StatSoft, Inc. (1998). Tulsa, OK, EUA. 
Resultados 


\section{5 - RESULTADOS}

T incialmente, demonstram-se as tabelas dos resultados do erro do estudadas. Em seguida, a tabela da compatibilização das idades iniciais, tempo de tratamento e quantidade de sobressaliência existente, bem como a da compatibilização do gênero entre os grupos. Após, tabela com os resultados da avaliação e comparação do grau de reabsorção radicular nos grupos; sua distribuição percentual entre eles; o teste de avaliação da distribuição normal das variáveis cefalométricas; as médias dos valores cefalométricos encontrados; a tabela dos resultados do teste "t", referente às alterações cefalométricas entre as fases final e inicial dos 2 grupos; a tabela da correlação do grau de reabsorção com o tempo de tratamento, com as quantidades iniciais e alterações da sobressaliência, bem como com a quantidade de movimento vertical e horizontal dos ápices dos incisivos centrais entre as fases inicial e final do tratamento.

No apêndice, encontram-se as características individuais de cada paciente, os escores aplicados a cada dente analisado radiograficamente e os valores individuais das medidas cefalométricas pré e pós-tratamento, além dos valores obtidos pela primeira e segunda medição para o erro do método, e para a concordância inter-examinadores, dispostos nas tabelas A1 a A16.

\subsection{Erro do Método e Concordância Inter-examinadores}

Referem-se aos resultados do teste intra-examinador, realizado no Grupo 1, e entre os examinadores, realizado no Grupo $2^{18}$. Neste, a segunda medição foi realizada pelo examinador 2, autor desta tese. Para verificar o grau de concordância entre a primeira e a segunda avaliação com relação ao grau de reabsorção, aplicou-se o teste de concordância kappa. Os resultados estão apresentados na tabela 1 .

A comparação da primeira e da segunda medição das grandezas cefalométricas foi realizada por meio do teste "t" dependente e da fórmula de 
Dahlberg, permitindo avaliar os erros sistemáticos e casuais respectivamente, estando presentes na tabela 2 os resultados para o erro do método e na tabela 3 para a concordância inter-examinadores.

TABELA 1 - Avaliação da concordância na classificação do grau de reabsorção intra e inter-examinadores (teste de concordância kappa ponderado).

\begin{tabular}{|c|c|c|c|}
\hline Grau de reabsorção & $\begin{array}{c}\text { Concordância } \\
\text { (\%) }\end{array}$ & $\begin{array}{c}\text { Kappa } \\
\text { ponderado }^{78}\end{array}$ & $\begin{array}{c}\text { Nível de } \\
\text { concordância }^{126}\end{array}$ \\
\hline $\begin{array}{c}\text { Grupo 1 - Intra- } \\
\text { examinador }\end{array}$ & $85 \%$ & 0,85 & Quase Perfeito \\
\hline $\begin{array}{c}\text { Grupo 2 - Inter- } \\
\text { examinadores }\end{array}$ & $75 \%$ & 0,62 & Substancial \\
\hline
\end{tabular}

TABELA 2 - Avaliação dos erros sistemáticos e casuais das medições cefalométricas intra-examinador (teste "t" dependente e fórmula de Dahlberg)

\begin{tabular}{|c|c|c|c|c|c|c|c|}
\hline Variáveis & $1^{\circ} \mathrm{Me}$ & dição & $2^{\circ} \mathrm{Mec}$ & dição & $\mathbf{t}$ & $p$ & Dahlberg $^{67}$ \\
\hline Pré-tratamento & Média & DP & Média & DP & & & \\
\hline Sobressaliência & 5,973 & 2,094 & 5,893 & 1,994 & 0,602 & 0,556 & 0,36 \\
\hline Sobremordida & 4,5 & 0,857 & 4,493 & 1,115 & 0,035 & 0,972 & 0,5 \\
\hline IS.PP & 113,04 & 7,811 & 112,826 & 7,412 & 0,685 & 0,504 & 0,84 \\
\hline AIS-PP & 3,96 & 2,149 & 3,926 & 1,831 & 0,171 & 0,865 & 0,51 \\
\hline AIS-ENAperp & 8,853 & 2,22 & 8,38 & 2,445 & 1,649 & 0,121 & 0,83 \\
\hline Pós-tratamento & & & & & & & \\
\hline Sobressaliência & 2,606 & 1,254 & 2,706 & 1,291 & $\begin{array}{c}- \\
1,029\end{array}$ & 0,32 & 0,27 \\
\hline Sobremordida & 1,813 & 0,843 & 1,86 & 0,917 & $\begin{array}{c}- \\
0,593\end{array}$ & 0,562 & 0,21 \\
\hline IS.PP & 113,68 & 6,952 & 114,073 & 7,338 & - & 0,233 & 0,88 \\
\hline
\end{tabular}




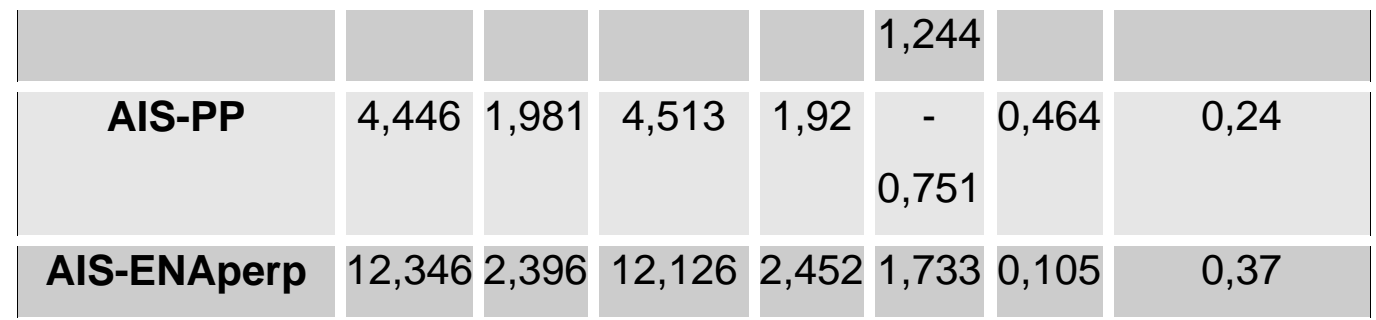

Diferença estatística não significante.

TABELA 3 - Avaliação dos erros sistemáticos e casuais das medições cefalométricas inter-examinadores (teste " $\mathrm{t}$ " dependente e fórmula de Dahlberg)

\begin{tabular}{|c|c|c|c|c|c|c|c|}
\hline \multirow[t]{2}{*}{ Pré-tratamento } & \multicolumn{2}{|c|}{$\begin{array}{c}1^{\circ} \text { Medição } \\
\text { Examinador } \\
1\end{array}$} & \multicolumn{2}{|c|}{$\begin{array}{c}2^{\circ} \text { Medição } \\
\text { Examinador } \\
2\end{array}$} & \multirow[t]{2}{*}{$t$} & \multirow[t]{2}{*}{$p$} & \multirow[t]{2}{*}{ Dahlberg $^{67}$} \\
\hline & Média & DP & Média & DP & & & \\
\hline Sobressaliência & 5,946 & 3,271 & 6 & 3,235 & 0,229 & 0,821 & 0,61 \\
\hline Sobremordida & 0,993 & 0,914 & 1,066 & 1,507 & 0,320 & 0,753 & 0,61 \\
\hline IS.PP & 115,16 & 6,912 & 115,146 & 6,545 & $\begin{array}{c}- \\
0,021\end{array}$ & 0,983 & 1,67 \\
\hline AIS-PP & 5,5 & 2,698 & 5,34 & 2,429 & $\begin{array}{c}- \\
0,551\end{array}$ & 0,59 & 0,78 \\
\hline AIS-ENAperp & 10,973 & 2,358 & 11,146 & 2,179 & 0,52 & 0,611 & 0,89 \\
\hline
\end{tabular}

Pós-tratamento

Sobressaliência
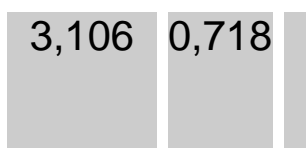

$2,96 \quad 0,907$

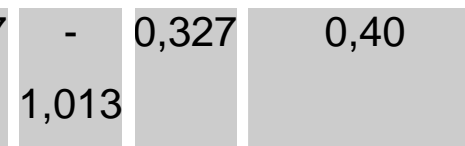

Sobremordida

1,34

0,912

1,533

$0,8591,2410,234$

0,43

IS.PP

$113,3065,314113,1465,341-0,240,813$

1,76

AIS-PP

$5,493 \quad 2,883$

5,66

$2,429 \quad 0,62 \quad 0,544$

0,72

AIS-ENAperp

\begin{tabular}{l|l|llll}
13,306 & 1,812 & 13,8 & 2,857 & 0,924 & 0,371
\end{tabular} 1,45 
Diferença estatística não significante.

\subsection{Compatibilização entre os Grupos}

Para verificar a compatibilidade entre os grupos quanto à idade inicial, ao tempo de tratamento e às quantidades de sobressaliência e sobremordida existente no início do tratamento aplicou-se o teste "t" independente (tabela 4). Para verificar a compatibilidade entre os grupos quanto ao gênero, realizou-se o teste qui-quadrado (Tabela 5). Os grupos estavam compatíveis quanto à idade, ao tempo de tratamento e à quantidade de sobressaliência, e significantemente diferentes quanto à quantidade de sobremordida. Em relação ao gênero, ambos os grupos possuíam a mesma quantidade de indivíduos do gênero masculino, e o mesmo ocorreu quanto ao feminino, estando eles perfeitamente compatíveis.

TABELA 4 - Médias e desvios padrão das idades iniciais, tempos de tratamento, quantidades de sobressaliência e de sobremordida, e a compatibilização entre os grupos (teste "t" independente).

\begin{tabular}{|c|c|c|c|c|c|}
\hline \multirow[t]{2}{*}{ Variável } & \multicolumn{2}{|c|}{ G1(n=28) } & \multicolumn{2}{|c|}{ G2 $(n=28)$} & \multirow[b]{2}{*}{$\mathbf{p}$} \\
\hline & Média & dp & Média & dp & \\
\hline Idade Inicial (anos) & 13,41 & 2,38 & 13,27 & 1,85 & 0,8098 \\
\hline $\begin{array}{l}\text { Tempo de tratamento } \\
\text { (meses) }\end{array}$ & 27,95 & 9,35 & 29,43 & 7,16 & 0,5117 \\
\hline Sobressaliência inicial & 6,48 & 2,52 & 5,67 & 2,73 & 0,2502 \\
\hline Sobremordida inicial & 4,78 & 1,18 & 1,12 & 0,97 & $0,0000 *$ \\
\hline
\end{tabular}

*Estatisticamente significante para $p<0,05$

TABELA 5 - Compatibilização da distribuição dos diferentes gêneros entre os grupos 1 e 2 (teste qui-quadrado).

\begin{tabular}{|l|l|c|c|}
\hline Masculino & Feminino & Total & $\begin{array}{c}\text { qui- } \\
\text { quadrado }\end{array}$ \\
\hline
\end{tabular}




\begin{tabular}{|c|c|c|c|c|}
\hline & & & & $\mathbf{p}$ \\
\hline G1 & 16 & 12 & 28 & \multirow{3}{*}{1,00} \\
\hline G2 & 16 & 12 & 28 & \\
\hline Total & 32 & 24 & 56 & \\
\hline
\end{tabular}

Diferença estatística não significante.

Para comparar a quantidade de reabsorção entre os dois grupos, foi utilizada a média de reabsorção dos quatro incisivos de cada paciente, aplicando o teste não-paramétrico Mann-Whitney. O resultado revelou maior reabsorção no grupo 1, tratado com mecânicas intrusiva e retrusiva, em relação ao grupo 2, tratado apenas com mecânica retrusiva (tabela 6).

TABELA 6 - Comparação da quantidade de reabsorção entre os grupos (teste Mann-Whitney).

\begin{tabular}{|c|c|c|c|c|c|c|}
\hline $\begin{array}{c}\text { Grau de } \\
\text { reabsorção }\end{array}$ & \multicolumn{2}{|c|}{ G 1 } & \multicolumn{2}{|c|}{ G 2 } & U & p \\
\hline Média & $\begin{array}{c}\text { Posto } \\
\text { médio }\end{array}$ & Média & $\begin{array}{c}\text { Posto } \\
\text { médio }\end{array}$ & \\
\hline & 2,375 & 36,05 & 1,696 & 20,94 & 180,5 & $0,0005^{*}$ \\
\hline
\end{tabular}

*Estatisticamente significante para $p<0,05$

\subsection{Análise Descritiva do Grau de Reabsorção Radicular}

Após a classificação do grau de reabsorção entre os grupos, avaliou-se a seguinte distribuição em cada grupo (Tabela 7):

Grupo 1 - Dos 112 dentes avaliados, todos apresentaram reabsorção detectável radiograficamente, sendo 19 dentes com reabsorção leve (grau1), 39 com reabsorção moderada (grau 2), 47 exibiram reabsorção acentuada (grau 3) e 7 dentes apresentaram reabsorção extrema (grau 4).

Grupo 2 - Dos 112 dentes avaliados, todos apresentaram reabsorção detectável radiograficamente, sendo que 43 dentes demonstraram reabsorção 
leve (grau 1), 58 reabsorção moderada (grau 2), 11 dentes reabsorção acentuada (grau 3) e nenhum deles apresentou reabsorção extrema (grau 4).

TABELA 7 - Distribuição quantitativa e percentual dos dentes de acordo com o grau de reabsorção radicular apresentado em ambos os grupos:

\begin{tabular}{|c|c|c|c|c|c|}
\hline \multirow[t]{2}{*}{ Escores } & \multicolumn{2}{|c|}{$\begin{array}{c}\text { G } 1 \\
\text { (número = 112) }\end{array}$} & \multicolumn{2}{|c|}{$\begin{array}{c}\text { G } 2 \\
\text { (número = 112) }\end{array}$} & \multirow{2}{*}{$\begin{array}{c}\text { Total } \\
(\mathrm{n}= \\
224)\end{array}$} \\
\hline & Número & $\%$ & Número & $\%$ & \\
\hline 0 & 0 & 0,00 & 0 & 0,00 & 0 \\
\hline 1 & 19 & 16,96 & 43 & 38,39 & 62 \\
\hline 2 & 39 & 34,82 & 58 & 51,78 & 97 \\
\hline 3 & 47 & 41,96 & 11 & 9,82 & 58 \\
\hline 4 & 7 & 6,25 & 0 & 0 & 7 \\
\hline
\end{tabular}

\subsection{Avaliação das Variáveis Cefalométricas}

As médias das variáveis cefalométricas de ambos os grupos estão presentes na tabela 8 tanto da fase inicial (T1) como final (T2).

As médias e os desvios padrão da variação das mesmas durante as fases T2-T1, foram avaliadas inicialmente pelo teste Kolmogorov-Smirnov, demonstrando que todas as variáveis apresentam distribuição normal, nos dois grupos estudados.

Dessa forma, as alterações cefalométricas puderam ser comparadas durante a fase T2-T1, entre os grupos, pelo teste " $\mathrm{t}$ " independente. A quantidade de alteração que apresentou diferença estatisticamente significante entre os grupos foi a correspondente à correção da sobremordida (Tabela 9).

TABELA 8 - Média das variáveis cefalométricas nas fases T1 e T2. 


\begin{tabular}{|c|c|c|c|c|}
\hline Variáveis & \multicolumn{2}{|c|}{ Grupo 1 (médias) } & \multicolumn{2}{|c|}{ Grupo 2 (médias) } \\
\hline Fase & Inicial & Final & Inicial & Final \\
\hline Sobressaliência & 6,489 & 2,585 & 5,671 & 3,01 \\
\hline Sobremordida & 4,785 & 1,939 & 1,128 & 1,285 \\
\hline IS.PP & 113,11 & 111,389 & 114,296 & 112,585 \\
\hline AIS-PP & 4,335 & 4,257 & 5,242 & 5,196 \\
\hline AIS-ENAperp & 9,825 & 12,717 & 10,785 & 13,225 \\
\hline
\end{tabular}

TABELA 9 - Alterações das variáveis cefalométricas entre as fases T2-T1 e a comparação entre os grupos (teste "t" independente)

\begin{tabular}{|c|c|c|c|c|c|}
\hline \multirow[b]{2}{*}{ Variáveis } & \multicolumn{2}{|c|}{ Grupo 1} & \multicolumn{2}{|c|}{ Grupo 2} & \multirow[b]{2}{*}{$\mathbf{p}$} \\
\hline & Média & D.P. & Média & D.P. & \\
\hline $\begin{array}{c}\text { Sobressaliência T2- } \\
\text { T1 }\end{array}$ & $-3,903$ & 2,355 & $-2,66$ & 2,733 & 0,073 \\
\hline $\begin{array}{c}\text { Sobremordida T2- } \\
\text { T1 }\end{array}$ & $-2,842$ & 1,123 & 0,16 & 1,345 & 0,000 * \\
\hline IS.PP T2-T1 & $-1,721$ & 8,87 & $-1,71$ & 9,255 & 0,996 \\
\hline AIS-PP T2-T1 & $-0,078$ & 1,655 & $-0,046$ & 1,26 & 0,935 \\
\hline AIS-ENAperp T2-T1 & 2,892 & 2,436 & 2,439 & 2,162 & 0,464 \\
\hline
\end{tabular}

*Estatisticamente significante para $p<0,05$

\section{5 - Correlação entre o Grau de Reabsorção e as Variáveis}

Avaliou-se, por meio do teste de correlação de Spearman, se há correlação entre o grau de reabsorção dos incisivos de toda a amostra com o 
tempo de tratamento, a sobressaliência e a sobremordida iniciais. A quantidade de deslocamento dos ápices nos sentidos vertical e horizontal e a inclinação dentária também foram correlacionados, porém pelo fato de apenas os incisivos centrais terem sido marcados nos cefalogramas, a correlação com essas medidas foram realizadas apenas com esses dentes (Tabela 10).

TABELA 10 - Avaliação da correlação do grau de reabsorção com o tempo de tratamento, com as alterações na sobremordida e sobressaliência e com os movimentos verticais e horizontais dos incisivos centrais durante as fases T2T1 (teste de correlação de Spearman).

\begin{tabular}{|c|c|c|c|}
\hline Variáveis & N & R & p* \\
\hline Reabsorção X Tempo de Tratamento & 56 & 0,127 & 0,349 \\
\hline Reabsorção X Sobremordida T1 & 56 & 0,324 & $0,014^{*}$ \\
\hline Reabsorção X Sobressaliência T1 & 56 & 0,184 & 0,173 \\
\hline Reabsorção X Sobremordida T2-T1 & 56 & $-0,32$ & $0,015^{*}$ \\
\hline Reabsorção X Sobressaliência T2-T1 & 56 & $-0,219$ & 0,104 \\
\hline Reabsorção ICS X IS.PP T2-T1 & 56 & $-0,186$ & 0,169 \\
\hline Reabsorção ICS X AIS-PP T2-T1 & 56 & 0,176 & 0,193 \\
\hline Reabsorção ICS X AIS-ENAperp T2-T1 & 56 & 0,043 & 0,75 \\
\hline
\end{tabular}

*Estatisticamente significante para $p<0,05$ 


\subsection{Comparação do Grau de Reabsorção entre os Dentes}

O grau de reabsorção foi comparado entre os incisivos centrais e laterais, em ambos os grupos (Tabela 11). Para isso, utilizou-se o teste de Wilcoxon, sendo considerada a média dos escores. Os resultados demonstraram que os incisivos centrais e laterais superiores não apresentaram diferença estatisticamente significante em ambos os grupos.

TABELA 11 - Comparação do grau de reabsorção radicular entre os incisivos centrais e laterais, dos grupos 1 e 2 (teste de Wilcoxon).

\begin{tabular}{|c|c|c|c|c|c|}
\hline Grupos & N & $\begin{array}{c}\text { IC } \\
\text { (média) }\end{array}$ & $\begin{array}{c}\text { IL } \\
\text { (média) }\end{array}$ & T & p \\
\hline Grupo 1 & 56 & 2,375 & 2,375 & 217,5 & 1 \\
\hline Grupo 2 & 56 & 1,66 & 1,767 & 57 & 0,214 \\
\hline Diferença estatística não significante. & & & \\
\hline
\end{tabular}


Discussão 


\section{6 - DISCUSSÃO}

4 reabsorção apical externa é um efeito comum, porém evitada quando seu diagnóstico é realizado precocemente por meio de radiografias periapicais realizadas ao início e em determinadas fases durante 0 tratamento $^{47,57}$.

Embora existam muitos trabalhos sobre reabsorção radicular, poucos têm se preocupado em avaliar as respostas dos tecidos dentários às forças ortodônticas bastante lesivas e intensas com critérios bastante rígidos de seleção e construção da amostra, bem como de avaliação através de técnicas adequadas de obtenção das imagens e rigor nas análises casuísticas. A maioria deles, tem correlacionado a reabsorção com as forças intrusivas 69,157, de retração ${ }^{93}$ e tipos de técnicas diferentes ${ }^{29,109}$, não associando movimentos.

Causas como susceptibilidade individual, predisposição genética e fatores sistêmicos muitas vezes foram citados, mas sem comprovação embasada cientificamente ${ }^{55,60-63}$. Apesar de muitos estudos se preocuparem em definir esses fatores etiológicos da reabsorção, além do tratamento ortodôntico, hoje se sabe com clareza que estes fatores não podem ser considerados como etiológicos para a reabsorção. $\mathrm{Na}$ verdade, a maioria desses estudos foram concluídos com algumas especulações, sem comprovações embasadas cientificamente, como discutido por CONSOLARO ${ }^{61-63}$ em 2004.

Os estudos recentes mostram que as causas locais são as que desencadeiam o processo e à eles deve-se enfocar as pesquisas para se obter o máximo de conhecimento a respeito. Para MIRABELLA; ARTUN ${ }^{157}$, em 1995, citam-se as características radiculares, ósseas e as forças e movimentos à que os dentes são impostos, corroborando com inúmeros outros autores ${ }^{57,120,205,206}$. Os fatores relacionados ao tratamento ortodôntico revelam-se os maiores responsáveis pelo aumento da quantidade de reabsorções ${ }^{2,14,29,150,156,157}$, e por 
esses fatores entende-se principalmente as forças que os aparelhos e dispositivos impõem aos dentes para movimentá-los,

O movimento de retração é um movimento agressivo imposto aos elementos dentários ${ }^{13,18,44,109}$, e o movimento de intrusão também é classificado como bastante lesivo e que freqüentemente ocasiona seqüelas irreversíveis $^{16,31,51,177,196,246}$. Dessa forma, associando-se os movimentos de intrusão e retração e realizando-os de forma simultânea ou seqüencial, seria lícito conjecturar que esse tipo de movimento conjugado seja o mais agressivo que se possa impor a um elemento dentário?

O movimento é executado concentrando uma força excessiva em menor área periodontal, visto que o movimento de intrusão e retração, quando isolados e puros, de acordo com CHOY et al. ${ }^{53}$, em 2000 e CONSOLARO ${ }^{58}$ em 2002, não causariam reabsorções devido à ampla área de distribuição das forças $^{196}$. De imediato, poderia se argumentar em evitá-lo ao máximo, eliminando as prováveis seqüelas severas que o mesmo traria às estruturas de suporte dentário. Porém, esse tipo de movimento é realizado com bastante freqüência, pois é a forma de correção da maioria das Classes II acentuadas, onde se observa a presença de um sobrepasse horizontal aumentado causado por uma discrepância ântero-posterior dos arcos, estando o superior à frente e o inferior para trás, e consequentemente uma maior extrusão dos dentes anteriores devido à falta de contato entre eles ${ }^{28,184}$.

É necessário avaliar durante as mecânicas ortodônticas o que pode causar as reabsorções para que, de forma preventiva, possibilite evitá-las ou atenuá-las para que se apresentem clinicamente insignificantes. Essa avaliação só pode ser realizada pelo exame radiográfico, que se constitui o material de estudo da imensa maioria das pesquisas realizadas. Segundo SAMESHIMA; ASGARIFAR ${ }^{203}$, em 2001, muitos trabalhos utilizaram radiografias indevidas para avaliar a reabsorção, com técnicas incorretas e falta de padronização no processo de obtenção e avaliação das imagens, o que pode levar a conclusões sem fundamentos verdadeiros ${ }^{22,128}$. Segundo o autor, as radiografias panorâmicas podem superestimar uma reabsorção existente em $20 \%$ ou até mais. 
Devido à ocorrência de vários fatores que poderiam mascarar ou alterar os reais efeitos de reabsorção causados pela mecânica ortodôntica ${ }^{59}$, e que poderiam resultar em possíveis erros, selecionou-se a amostra pelos critérios estabelecidos evitando variáveis que pudessem gerar resultados conflitantes ou duvidosos. PARKER; HARRIS ${ }^{177}$ em1998 salientam, ainda, ser bastante difícil isolar e também avaliar movimentos específicos do dente para estudo, pois num tratamento completo ocorre um somatório amplo de vários movimentos, mesmo que alguns deles prevaleçam.

A discussão foi dividida nos seguintes tópicos:

\subsection{Considerações relacionadas à amostra}

\subsection{Considerações relacionadas à metodologia}

6.2.1 Medição da reabsorção radicular

6.2.2 Medição do trespasse

6.2.3 Medição dos movimentos dentários

6.2.4 Digitalização das imagens radiográficas

6.2.4.1 Radiografias periapicais

6.2.4.2 Telerradiografias

6.2.5 Precisão da metodologia

\subsection{Discussão dos resultados}

6.3.1 Compatibilização entre os grupos

6.3.2 Comparação do grau de reabsorção entre os grupos

6.3.3 Correlação entre as variáveis

6.3.4 Comparação da reabsorção entre os incisivos

\subsection{Implicações clínicas}

\subsection{Sugestões para novos trabalhos}




\subsection{Considerações Relacionadas à Amostra}

É importante salientar a dificuldade de se encontrar uma amostra com 30 ou mais pacientes em cada grupo que preencha precisamente tantos requisitos como os relatados anteriormente no capítulo Material e Métodos. Embora, em pesquisas científicas deva-se procurar a exatidão, precisão e perfeição, a adequação constitui o padrão mais freqüentemente alcançado ${ }^{122}$.

A montagem do Grupo 1 pode servir para exemplificar o anteriormente explanado. Inicialmente, observando-se os modelos localizou-se 116 pacientes com as características de trespasse procurado, pois ao se avaliar primeiramente esse critério já se eliminam os casos que não são de interesse. Esse número exagerado de pacientes foi necessário devido às outras características importantes e necessárias que eram perquiridas também nos outros exames pertencentes à documentação do paciente.

Após esse primeiro critério de exclusão avaliaram-se as radiografias panorâmicas com a finalidade de se constatar a presença de dentes extranumerários, agenesias, impacções, tratamentos endodônticos, lesões patológicas, raízes mal formadas e dentes com rizogênese incompleta. Assim, mais alguns casos foram eliminados, resultando 81 pacientes potenciais para serem utilizados.

O próximo passo foi a avaliação dos dentes que seriam analisados nas radiografias periapicais, e essa etapa incluiu além da presença dessas radiografias, também a avaliação da qualidade do exame realizado, ou seja, a densidade radiográfica, a técnica adequadamente realizada, o bom enquadramento das imagens e com mínima distorção, máximo detalhe e excelente visibilidade, nas radiografias iniciais e também nas finais. Esta avaliação impediu que determinados pacientes fossem utilizados, pois são dois exames obtidos em épocas e por operadores diferentes e muitas vezes ou o pré ou o pós-tratamento não foram realizados ou não puderam ser aproveitados. A ausência de radiografias pré ou pós-tratamento diminuiu o número para 59 pacientes, e deste grupo remanescente apenas 40 deles possuíam radiografias tecnicamente aproveitáveis para o estudo. 
Esses pacientes foram submetidos à análise estatística para compatibilizar e aproximar suas características às do grupo controle e, por todos esses motivos e após a compatibilização, a amostra finalizou com um grupo de 28 pacientes com características ideais, para serem comparados e estudados.

Deve-se considerar que os elementos da amostra selecionada foram tratados por diversos profissionais. No entanto, há a vantagem de que dessa forma elimina-se alguma tendenciosidade que possa ter sido incorporada aos tratamentos em decorrência da atuação de um único profissional. KJAER ${ }^{120}$ em 1995, BAUMRIND; KORN; BOYD ${ }^{14}$ em 1996 e outros pesquisadores ${ }^{87,167,179,188,203,243}$ apresentam amostras com diferentes procedências e profissionais atuando e não ressaltam esse fator como uma interferência aos resultados obtidos.

Os casos tratados com extrações apresentam uma quantidade de reabsorção maior que aqueles sem extrações ${ }^{18,113,117,151,203,204,206,212}$, possivelmente devido à maior movimentação causada pelo processo de retração. Mas seria essa a principal causa da reabsorção observada nos casos tratados com extrações?

Para CHOY et al., 2000 e CONSOLARO ${ }^{58}$, 2002, o movimento intrusivo puro não causa reabsorção dentária, pois há uma grande área para a dissipação das forças aplicadas, então muito pouco dela seria causada pela associação do movimento de intrusão.

Assim, optou-se por estudar um grupo submetido à extrações e conseqüentemente com retração anterior e um trespasse vertical excessivo presente, necessitando do movimento de intrusão para sua correção, e a ele comparar outro grupo com a mesma quantidade média de trespasse horizontal, de correção desse trespasse e também de deslocamento horizontal apical, medidos através da telerradiografia, porém sem apresentar nenhum relato de mecânica intrusiva em seu tratamento.

Durante a seleção dos pacientes para os grupos, distribuíram-se uniformemente as quantidades de casos com Classes I e II com o intuito de diminuir a influência de diferentes mecânicas sobre os resultados. Porém, 
casos com trespasse horizontal acentuado associado a um trespasse vertical excessivo, na sua imensa maioria são más oclusões de Classe II, sendo raro se encontrar Classe I com quantidades acentuadas de trespasse vertical associado ao horizontal ${ }^{24,28,184}$.

Como muitos estudos afirmam que pacientes com Classe II apresentam maior movimentação dentária aumentando assim o tempo de tratamento e conseqüentemente acarretarem maior reabsorção ${ }^{14,38,70,148,157,206,214,227,247}$, tomou-se o cuidado de se compatibilizar, isto é, manter o mais próximo possível as quantidades de trespasse horizontal pré-tratamento de ambos os grupos, e isto foi conseguido, conforme mostra a tabela 4. Da mesma forma, a quantidade de deslocamento horizontal que ocorreu nos ápices em ambos os grupos foi muito semelhante, bem como o tempo de tratamento, pois em todos os casos foram realizadas extrações no arco superior, objeto deste estudo. Portanto essa variável não apresenta diferença perceptível entre os dois grupos.

Foram avaliados apenas os incisivos superiores, pois os estudos analisados comprovam serem estes os dentes que mais reabsorvem durante 0 tratamento ortodôntico ${ }^{18,47,51,70,109,115,179,226}$. São os dentes mais movimentados e os que sofrem ação mais freqüente desse extenso movimento, de retração ou intrusão quando da correção da má oclusão em estudo ${ }^{13,44,109,147,177}$. Os dentes inferiores sofrem geralmente o mesmo tipo de reação nos seus tecidos biológicos quando submetidos ao mesmo tipo de movimento, quantidade de extensão e força, porém em quantidade notavelmente menor $^{1,2,16,18,29,51,70,109,119,179,188}$.

Os grupos apresentavam-se compatíveis quanto à idade de início do tratamento, eliminando assim possíveis influências na quantidade de reabsorção encontrada ${ }^{205,227}$. LINGE; LINGE ${ }^{137}$, em 1991, afirmaram que a delimitação da idade reduz o problema do crescimento, o que poderia interferir na mensuração da quantidade de reabsorção e homogeneizar as circunstâncias do tratamento.

Os dentes com endodontias prévias ao tratamento foram excluídos da amostra para evitar resultados conflitantes, com respostas imprevisíveis, 
dificultando a interpretação dos resultados. MENDONÇA ${ }^{155}$ em 1997 afirma que nesses casos a reabsorção radicular poderia se apresentar diferentemente do que em pacientes com dentes vitais ${ }^{114,157,188,219,245}$ e as medições poderiam ser dificultadas visto algumas situações clinicas que poderiam ocorrer, como exposição de cones obturadores e reativação de lesões apicais, assegura CONSOLARO ${ }^{58}$, em 2002.

Casos que já apresentaram algum tratamento ortodôntico no passado também foram eliminados, apesar de na faixa etária estudada com a má oclusão apresentada isso não ter ocorrido. Isso se deve à possibilidade de também interferirem nos processos de reabsorção, uma vez que reabsorções prévias já possam existir, bem como áreas de reparo ${ }^{58}$.

Foram eliminados os dentes sofreram traumas também para se evitar resultados contestáveis, pois exarcebariam os valores encontrados $^{58,136,141,212}$.

Pacientes com caninos superiores impactados foram também excluídos da amostra, pois segundo ERICSON; KUROL ${ }^{75,76}$ em seus artigos de 1987 e 1988, esses dentes podem gerar reabsorção nos incisivos laterais ${ }^{37,136}$, sendo a força exercida durante o tracionamento a maior causadora ${ }^{136}$.

\subsection{Considerações Relacionadas à Metodologia}

\subsubsection{Medição da quantidade de reabsorção radicular}

A avaliação das raízes dentárias pelas radiografias periapicais é o método utilizado na maioria dos outros estudos sobre reabsorção radicular $^{18,29,43,51,69,94,100,119,130,131,136,137,141,143,167,171,195,219,243}$ uma vez que, segundo SAMESHIMA; ASGARIFAR ${ }^{203}$, em 2001, esse tipo de radiografia apresenta detalhes mais refinados, permitindo visualização de detalhes anatômicos como a junção cemento-esmalte e apresentam menos distorções e sobreposições quando comparado às radiografias panorâmicas e telerradiografias $^{128,130}$. Estas últimas foram utilizadas em vários estudos, mas 
as periapicais oferecem menor radiação ao paciente e as comparações são mais fiéis, não comprometendo a metodologia na medição da quantidade de reabsorção ${ }^{46,128,203}$.

As vantagens são ainda maiores quando as periapicais são obtidas pela técnica do paralelismo, pois permite uma maior padronização da imagem para avaliação pré/pós-tratamento ${ }^{7,86,127,128,153}$, o que não é possível pela técnica da bissetriz, pois o ângulo médio de incidência dos raios-x é mais difícil de ser reproduzido dificultando ainda mais a acuracidade de mensurações quantitativas $^{22,128,188}$.

Como são duas obtenções de imagens em épocas diferentes, ou seja, antes e depois do tratamento, algumas intercorrências podem acontecer devido ao tempo entre as tomadas, que na ortodontia pode ser relativamente longo. Como exemplo pode-se citar o fato de serem realizadas em clínicas diferentes, por profissionais diferentes, que utilizaram também filmes diferentes, gerando, assim, falta de padronização das imagens radiográficas. Some-se ainda ao fato que a realização do exame se dá sem um posicionamento fixo do paciente e da película, precisamente irreprodutível na primeira e na segunda realização do exame. Salienta-se ainda que, mesmo que houvesse um método extremamente fiel de posicionamento do paciente e da película na primeira e na segunda tomadas radiográficas, o objeto do exame, que é o dente, em se tratando de paciente submetido ao tratamento ortodôntico, não estará mais na mesma posição ${ }^{157,189}$.

Para CHAN; DARENDELILER ${ }^{50}$, em 2004, esses fatos todos resultam em exames que apresentam algumas imagens distorcidas, ou seja, um pouco alongadas ou encurtadas e mesmo que se tenham eliminado as radiografias com imagens excessivamente alteradas, manchadas ou mal posicionadas, as medições não poderiam ser confiáveis. Por esse motivo, uma metodologia de medição quantitativa em milímetros, por exemplo, avaliando a mudança do tamanho radicular, antes e após o tratamento, não poderia ser utilizada de maneira fiel.

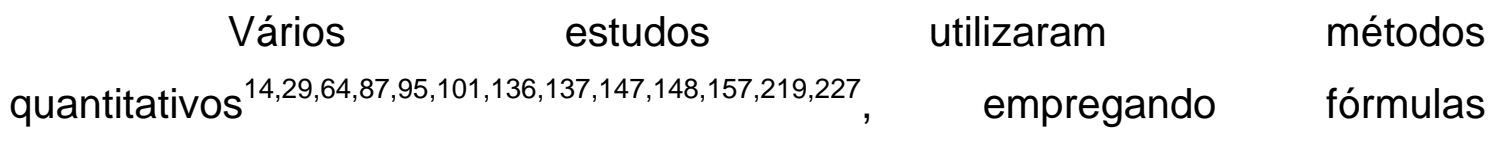


matemáticas para minimizar erros de alongamento/encurtamento da imagem do dente utiizando razão de proporção coroa/raiz nas radiografias pré e póstratamento para equivalê-las em tamanho e assim determinar a quantidade de material radicular perdido. Porém, este método pode apresentar deficiências, pois as raízes apresentam regiões curvas às vezes que, dependendo das posições raios-x/película/elemento dentário podem ser notáveis ao início e não ao final, e vice-versa, alterando a real proporção coroa/raiz. Se isso pode ser aplicado mesmo que em alguns poucos casos, já não se torna uma alternativa fiel de avaliação.

É com a localização da junção cemento-esmalte que se inicia a medição e a divisão entre a porção coronária e radicular. Para isso, necessitase exatidão para que a mensuração seja identificada com certo grau de precisão. Caso os dentes apresentem-se bem alinhados, característica menos comum nos casos ortodônticos, a identificação desse reparo anatômico tornase mais fácil e fiel. As projeções da junção são dificilmente localizadas em situações de apinhamento ou giroversão dentária e às vezes até impossíveis na presença de restaurações interproximais ${ }^{33,157}$. Por apresentar diferentes alturas em torno do dente, ou seja, nas faces vestibular, palatina ou lingual e proximais, as variações no ângulo de incidência dos raios $X$ a projeta de forma diferente dificultando a interpretação correta. As porções vestibular ou proximais da junção, dependendo a angulação imposta ou movimento de giroversão ocorrido, apresenta-se mais ou menos distante da película, ampliando ou distorcendo sua imagem, dificultando a interpretação ${ }^{33,65}$. Melhor seria se a primeira e a segunda obtenção das imagens fossem realizadas com película radiográfica, feixe de raios-x e o dente radiografado em posições iguais em ambas as tomadas. Assim se obteria uma fidelidade muito maior quanto à avaliação por esse método.

Elegeu-se então o método que classifica a reabsorção em escores, proposto por MALMGREN et al. ${ }^{141}$, de 1982. É utilizado com muita freqüência por diversos autores ${ }^{1,9,16,18,43,51,70,92,100,109,130,143,179,188,216}$, embora apresente um caráter subjetivo na interpretação dos valores. Sua principal vantagem é o fato de não depender da padronização das tomadas radiográficas. 
JANSON $^{109}$ et al., em 2000, modificaram essa classificação tornando-a qualitativa, eliminando a necessidade de medir o comprimento da perda radicular, como realizado no método original ${ }^{141}$, onde se observa que 0 grau 2 é atribuído às raízes com um encurtamento de até $2 \mathrm{~mm}$, enquanto que uma perda maior que este valor classifica-se como grau 3 , desde que a reabsorção não ultrapasse $1 / 3$ do comprimento radicular. Considerando a dificuldade em medir a reabsorção em milímetros devido às mudanças e aos possíveis erros de angulação durante a tomada radiográfica, optou-se por usar esta modificação ${ }^{109}$, que também se caracteriza por um sistema de escores, porém baseando-se nas alterações anatômicas das raízes.

\subsubsection{Medição dos trespasses}

Existem várias maneiras descritas na literatura para se realizar a mensuração dos trespasses vertical e horizontal, como já descrito na revisão da literatura. Neste estudo, o método eleito para avaliar o trespasse vertical é, certamente, o mais utilizado pelos pesquisadores e que produz resultados mais consistentes com a realidade.

A distância entre as bordas dos incisivos superiores e inferiores foi medida perpendicularmente ao plano oclusal. Quanto mais próximo estiver a referência em relação à variável a ser analisada, mais precisa será a avaliação, pois situa-se em uma área mais restrita e com menor quantidade de alterações como as que ocorrem no crescimento, por exemplo, caso a linha SN (selanásio) fosse utilizada, podendo interferir nas mensurações. Ao utilizar o plano oclusal como parâmetro, procurou-se empregar uma referência que sofresse as mesmas influências e variações que a medida a ser analisada, proporcionando resultados mais compatíveis com a realidade ${ }^{73,82,108,111,124,166}$ (FIG. 12).

A mensuração do trespasse horizontal foi realizada orientando-se pelo plano palatino, ou seja, a distância linear entre as bordas incisais dos incisivos centrais superiores e inferiores medida paralelamente ao plano palatino. 


\subsubsection{Medição dos movimentos dentários}

A movimentação dentária foi avaliada pela cefalometria, para correlacionar com a reabsorção radicular, neste trabalho, assim como em outros $^{65,69,97,136,148,227}$. Linhas de referências foram utilizadas para quantificar o deslocamento do ápice nos sentidos horizontal e vertical, demarcando-se pontos na própria base apical, onde se encontram os ápices radiculares, diminuindo a influência do crescimento craniofacial nos resultados.

Para evitar que a movimentação dentária, no sentido vertical, não fosse confundida e parecesse menor devido à diminuição do comprimento radicular pela reabsorção, essa medida do dente nos cefalogramas foi mantido idêntico. Com auxílio de uma régua milimetrada, o comprimento inicial do dente foi transferido para o cefalograma final, evitando-se assim que as alterações no comprimento dentário afetassem os resultados ${ }^{14,157}$.

Os movimentos de intrusão e de retração foram avaliados tomandose como referência um ponto na extremidade do ápice radicular. Para OTTO; ANHOLM; ENGEL ${ }^{173}$, de 1980, essa metodologia é mais precisa para a observação da quantidade de movimentos vertical e horizontal que o mesmo sofreu. Dessa maneira torna-se mais fiel a quantificação do deslocamento da raíz em sua base óssea, pois a borda incisal, devido às inclinações que os dentes podem sofrer, dificultaria essa medição de maneira correta $^{81,94,125,133,149,207,227,228}$. Quanto à dificuldade em demarcar este ponto e à possibilidade de se incorrer em erros matemáticos e possivelmente nos resultados, as avaliações do erro do método e inter-examinadores demonstraram um excelente nível de concordância entre as avaliações, pois não houve erro sistemático.

\subsubsection{Digitalização das imagens radiográficas}

É o processo de codificação de uma imagem, permitindo seu processamento e armazenamento no computador em forma de arquivo. Neste estudo o formato de arquivo de imagem utilizado foi o TIFF (Tag Image File 
Format) que, segundo SWARTZ ${ }^{225}, 2000$, não compacta as imagens no intuito de ocuparem menos espaço no computador, mas sim mantém a qualidade original desde sua obtenção pelo scanner, permitindo melhor avaliação das imagens, ao contrário do JPEG (Joint Photographic Experts Group) que apresenta várias taxas de compressão de imagem, sempre com alguma perda de qualidade.

Além das inúmeras ferramentas utilizadas neste processo, como ampliação das imagens, ajustes e correções necessárias para melhora da qualidade e padronização para melhor comparação, proporciona a exibição de várias ferramentas de medidas como réguas, grades e medições computadorizadas fiéis ${ }^{91,208,225}$. Permite ainda ser transportada e visualizada a qualquer momento na tela do computador, evitando-se assim a manipulação das documentações ortodônticas, que podem ser danificadas.

\subsubsection{Radiografias Periapicais}

A digitalização das radiografias periapicais foi realizada com um scanner para slides de $35 \mathrm{~mm}$ e as imagens salvas em um computador. As películas foram inseridas em cartelas e sempre com a mesma direção de inserção foram introduzidas uma a uma no scanner, para evitar a inversão da imagem e possível confusão na interpretação. As imagens não foram identificadas por nomes ou por grupos, e sim por números para evitar tendenciosidade dos resultados no momento da classificação do grau de reabsorção.

Após terem sido padronizadas em tamanho, brilho e contraste, manualmente uma a uma com auxílio do programa Adobe Photoshop CS, as imagens foram avaliadas e a quantidade de reabsorção quantificada. REUKERS $^{189}$ em 1998 afirma que o programa utilizado apresenta grande fidelidade e reprodutibilidade no preparo e arquivamento das imagens, auxiliando muito na obtenção de diagnósticos mais precisos. Também permite a ampliação da imagem para melhor visualização e, no caso, como foram escaneadas com 675 dpi, permite serem ampliadas em até 7 vezes sem 
nenhuma perda de definição e qualidade ${ }^{139,225}$, possibilitando assim se avaliar com maior precisão as reabsorções, mesmo aquelas mais incipientes ${ }^{26,32,34,57,83}$.

\subsubsection{Telerradiografias}

A avaliação das grandezas cefalométricas também foi computadorizada, permitindo a utilização de um maior número de dados em menor período de tempo, como também uma menor probabilidade de erros na obtenção dos valores, pois elimina-se a fase de medição e cálculos para a mensuração dos resultados, pois é realizado por um programa de computador.

O programa utilizado foi o Dentofacial Planner 7.02, bastante utilizado em pesquisas renomadas, tendo assegurada assim sua confiabilidade $25,30,48,109,110,181,220$. Proporciona medidas com precisão de 0,1mm e $0,1^{\circ}$ e também a correção do fator de magnificação, alteração no tamanho da imagem comum nesta técnica radiográfica. As medidas realizadas sobre uma telerradiografia ampliada encontram-se magnificadas na mesma proporção, e devem ser corrigidas principalmente pelo fato de terem sido obtidas em aparelhos distintos, com magnificações diferentes, alterando os resultados principalmente quando se calcula a quantidade de alteração, conseguido pelo tratamento ${ }^{106}$.

\subsubsection{Precisão da metodologia}

A avaliação da reabsorção radicular por meio de escores sugere a hipótese de se contar com menor confiabilidade e reprodutibilidade dos resultados obtidos por ser um método qualitativo visual e, portanto, com um forte componente subjetivo. Outra suspeita pode-se levantar quando da utilização de outra amostra para comparação, onde outro profissional realizou sua avaliação. Por esses motivos, realizou-se a avaliação do erro intraexaminador e inter-examinadores, demonstrando respectivamente o nível de 
concordância que o mesmo examinador apresenta ao avaliar os mesmos elementos duas vezes em um intervalo de tempo, e a concordância que ambos examinadores apresentam ao avaliarem, separadamente, outro grupo de elementos.

A porcentagem de concordância nas avaliações dos escores de reabsorção intra-examinador realizado no Grupo 1 apresentou-se em 85\%, e inter-examinadores, no Grupo 2, de 75\%, apresentando níveis considerados como "quase perfeito" e "substancial" respectivamente (Tabela 1), demonstrando a boa calibração do examinador e entre ambos, elevando o grau de confiabilidade e reprodutibilidade dos resultados apresentados.

Torna-se evidente, então, que esse é um método preciso e confiável, justificando sua ampla utilização na avaliação da reabsorção radicular $^{16,18,43,44,51,70,80,83,92,109,115,130,141,143,179,188,216}$.

Nas grandezas cefalométricas os erros casuais e sistemáticos foram testados pela fórmula de Dahlberg e pelo teste " $\mathrm{t}$ " pareado (Tabelas 2 e 3).

O erro casual refere-se à dificuldade de se identificar e definir certos pontos radiográficos utilizados nas medições cefalométricas ${ }^{106}$. Os valores encontrados apresentaram-se reduzidos, com as medidas lineares menores que $1 \mathrm{~mm}$ e as angulares menores que $2^{\circ}$, não aumentando consideravelmente o desvio-padrão das médias, o que se deve, provavelmente, à variabilidade dos grupos ${ }^{209}$.

Segundo HOUSTON ${ }^{106}$, em 1983, o erro sistemático reflete uma falta de padronização do método, uma vez que o examinador tende a sub ou superestimar os valores de suas medições de maneira inconsciente e persistente, involuntária ou de modo a direcionar os resultados de acordo com as suas expectativas em relação às conclusões do estudo. Contudo, as variáveis analisadas apresentaram-se todas com diferenças estatisticamente não significantes, tanto na avaliação intra-examinador como interexaminadores, demonstrando a precisão do método. 


\subsection{Discussão dos Resultados}

\subsubsection{Compatibilização entre os grupos}

As idades iniciais foram compatibilizadas quanto ao início do tratamento, como demonstra a Tabela 4. Algumas contradições ocorrem neste relacionamento da idade com a maior reabsorção radicular. Esse fato não foi comprovado por LUPI; HANDELMAN; SADOWSKI ${ }^{138}$, em 1996, mas outros autores observaram diferenças na quantidade de reabsorção radicular entre pacientes adolescentes e adultos ${ }^{136,205,227}$. Compatibilizar essa variável permite principalmente eliminar diferentes alterações do crescimento entre os grupos e que poderiam comprometer a interpretação dos resultados, ainda mais neste estudo, onde a faixa etária propicia grandes alterações faciais e comparam-se valores expressos em décimos de milímetros e de graus.

Os grupos foram compatibilizados quanto ao tempo de tratamento, pois o tempo durante o qual os aparelhos estão agindo pode influenciar a reabsorção apical ${ }^{187}$. Nesta pesquisa, o tempo de tratamento entre os grupos estudados apresentou-se compatível entre si, como demonstrado na Tabela 4. Há pesquisas que afirmam que não há correlação entre o grau de reabsorção radicular e o tempo de tratamento ${ }^{16,69,136,179}$, e outros insistem sua ocorrência ${ }^{14,38,148,157,206,214,227,247}$. Provavelmente essa disparidade se deva ao simples fato de que o tempo de tratamento maior não signifique uma má oclusão inicial mais severa, ou existência de maior quantidade de movimento dentário, ou até mesmo maior quantidade e duração da força colocada sobre os dentes, durante o tratamento. Se os casos que exigem movimentos mais extensos são os que demandam mais tempo, então não convém responsabilizar apenas a duração do tratamento, mas também a extensão do movimento. Pontifique-se que a quantidade de movimento não é diretamente proporcional ao tempo de tratamento, pois o aparelho pode estar presente com uma reduzida ação sobre os dentes ${ }^{157}$, seja pelas faltas do paciente às consultas de manutenção ou pelo intervalo mais prolongado entre as 
ativações $^{212}$. Da mesma forma, pode-se realizar muita movimentação em um intervalo curto de tempo, tendo como conseqüência uma maior reabsorção. Mas para eliminar dúvidas, selecionaram-se ambos os grupos com tempos de tratamento semelhantes,

No quesito gênero, ambos foram compatibilizados com o mesmo número em ambos os grupos (Tabela 5), apesar de não ser uma condição necessária para se avaliar as reabsorções, visto não haver correlação significativa com essa variável ${ }^{16,58,205,206}$.

Em relação às quantidades de sobremordida e sobressaliência, esta última foi compatibilizada para que possuíssem a mesma quantidade de retração e consequentemente de deslocamento horizontal dos incisivos, uma vez que a variável a ser estudada era apenas a de intrusão, isto é, o deslocamento vertical dos incisivos. Portanto, quando da seleção dos pacientes da amostra, procurou-se pacientes submetidos à extrações de pré-molares e que apresentassem inclusive sobressaliências semelhantes e, em seguida, ainda houve uma compatibilização maior feita com o auxílio da cefalometria, onde esse trespasse horizontal contou com valores aproximados ao máximo possível em ambos os grupos, remanescendo como diferença significante apenas a quantidade de trespasse vertical, que era acentuada no Grupo 1.

\subsubsection{Comparação do grau de reabsorção entre os grupos}

A quantidade de reabsorção radicular foi comparada entre os grupos pelo teste de Mann-Witney. O grupo com sobremordida profunda e com extrações (grupo 1), quando comparado ao grupo com sobremordida normal e com extrações (grupo 2) apresentou diferença estatisticamente significante no grau de reabsorção radicular (Tabela 6).

O grupo 1 apresentou a média de reabsorção dos incisivos superiores entre os escores 2 e 3 (2,375), considerada de moderada a acentuada, onde os ápices apresentam desde uma pequena perda radicular apical até a perda máxima de $1 / 3$ de seu comprimento. O grupo 2 , situou-se 
entre os graus 1 e $2(1,696)$, caracterizado de leve a moderado, onde os ápices apresentam desde uma irregularidade no seu contorno apical até uma perda apical que não comprometia o comprimento radicular. Pode-se então depreender com esse resultado que um dos fatores que contribuíu para esse maior grau de reabsorção dos incisivos foi a presença da mecânica intrusiva, causando maior força sobre os ápices para a movimentação dos incisivos durante a já considerável força de retração imposta para o fechamento dos espaços originados pelas extrações.

Ao analisar descritivamente o grau de reabsorção radicular, presente na Tabela 7, os grupos apresentaram diferentes porcentagens de dentes acometidos, nos 5 escores de reabsorção. Isso confirma realmente a hipótese que pacientes com sobremordida profunda apresentam maior grau de reabsorção que aqueles com trespasse vertical normal, mesmo submetidos à extrações durante o tratamento. O Grupo 1 apresentou maior porcentagem de dentes no grau $3(41,96 \%)$ do que o Grupo 2 (9,82\%). Já quando se observa o grau 2, o Grupo 2 apresentou mais da metade dos dentes reabsorvidos com este escore (51,78\%), enquanto o Grupo 1 apresentou uma parte bem menor com este escore, porém também considerável (34,82\%). Isso demonstra que o Grupo 1 apresenta um grande número de dentes com grau 3 e um pouco menos com grau 2, prevalecendo quase todos os dentes nesta faixa. Já o Grupo 2 apresenta a imensa maioria com grau 2, e praticamente quase todo 0 restante com grau 1, comprovando a maior quantidade de reabsorção no Grupo 1. Isso significa que pode-se esperar, nestes casos, que um processo de reabsorção ocorra com ou sem a mecânica de intrusão, porém quando esta mecânica é associada, um grau maior pode ser esperado.

A extração é um fator altamente significante para a reabsorção radicular, em decorrência da maior necessidade de movimento. Quanto maior a correção do trespasse horizontal durante o tratamento, maior a reabsorção ao final. Esse resultado foi encontrado na maioria das pesquisas $^{16,18,51,113,177,179,203,204,212}$ apesar de outros autores demonstrarem o contrário $^{14,105,148 .}$. 
Da mesma forma, a força intrusiva causa tensão principalmente no ápice radicular e implica, portanto, em danos nesta região do dente, resultando na reabsorção apical ${ }^{16,51,65,177,196,246}$. Portanto, espera-se um maior grau de reabsorção e um maior percentual de dentes reabsorvidos quando uma mecânica com intrusão esteja associada aos casos tratados com extrações, e isto foi confirmado nesta pesquisa.

\subsubsection{Alterações das variáveis entre os grupos}

As quantidades de Classes I e II entre os grupos eram distintas, pois um grupo submetido à extrações e apresentando sobremordida profunda geralmente apresenta Classe II, característica presente em todos os pacientes do Grupo 1. Já no Grupo 2, metade dos pacientes apresentava Classe I, fator que poderia estar interferindo nos resultados obtidos, uma vez que afirma-se ser diferente a quantidade de reabsorção quando há uso de elásticos intermaxilares e maior quantidade de retração dos dentes anteriores $^{38,136,137,157,206}$. No entanto, observa-se na Tabela 9, que ambos os grupos apresentaram quantidade de correção da sobressaliência e das inclinações dentárias similares. A comparação do tipo e quantidade de movimento realizado demonstrou que ambos os grupos apresentaram alterações estatisticamente semelhantes. O mesmo ocorre em relação aos movimentos apicais, onde a quantidade de deslocamento horizontal ocasionado pela retração no Grupo 1 foi estatisticamente similar ao do Grupo 2, e a quantidade de intrusão se manifestou da mesma forma. A variável que demonstrou quantidade diversa de alteração entre os grupos, pela diferente quantidade de correção, foi a sobremordida.

O que ocorre no tratamento da sobremordida é um somatório de fatores, que envolve a vestibularização $5,54,74,77,84,199,200$, a intrusão ${ }^{23,41,74,134}$ e nesta idade estudada, principalmente a restrição do crescimento alveolar no sentido vertical ${ }^{150}$. A protrusão dos incisivos decorrente do nivelamento da curva de Spee é um efeito comumente observado $5,15,54,74,77,84,199,200,213$ uma vez 
que a força é aplicada pelo fio no braquete que situa-se vestibularmente à coroa dentária, à frente do centro de resistência do dente, ocasionando um momento dirigindo a coroa para frente ${ }^{5,41,177,241}$. Assim, o ápice desloca-se para posterior ao mesmo tempo em que é intruído, tornando menor seu deslocamento vertical ${ }^{51}$.

O Grupo 1 apresentou uma correção considerável da sobremordida quando medida em sua porção incisal, comparando à do seu antagonista. Porém, a mesma quantidade de deslocamento vertical não foi encontrada quando a medida foi realizada no ápice em relação ao plano palatino. Este resultado vem ao encontro do auferido por CHIQUETO ${ }^{51}$, que em 2005 avaliou a intrusão em jovens com a mesma faixa etária.

Como a inclinação dentária não constituiu caráter significante para justificar essa alteração, visto que o movimento de vestibularização comum nas intrusões foi minimizado pela força de retração (Tabelas 8 e 9), pode-se computar as alterações do crescimento e no desenvolvimento dos arcos que ocorrem intensamente nesta faixa etária $20,66,79,199,200,248$. como sendo um dos responsáveis pela mudança encontrada, não demonstrando esse deslocamento apical vertical de intrusão de forma acentuada, como era esperado.

SAKIMA ${ }^{199,200}, 2000$, afirma que a mecânica empregada representa um grande poder de restrição do crescimento alveolar. Ocorre uma restrição efetiva do crescimento na região anterior do arco e indução em outras, promovido pela ação das curvas reversa e acentuada, corrigindo a sobremordida $20,66,79,248$, conseguindo ainda uma pequena intrusão. Conseqüentemente, pode-se atribuir ao efeito do uso dos arcos como apresentando um grande poder de restrição com um menor efeito de intrusão verdadeira, podendo ser até denominado como uma intrusão relativa, visto que a média de distância entre o ápice e o plano palatino seria maior ao final do crescimento, se não tivessem sofrido ação do aparelho ${ }^{20,161,198}$.

Com os resultados obtidos, especula-se que os arcos com curva reversa e acentuada promovam uma quantidade considerável de extrusão dentária na região posterior, principalmente no arco inferior, onde a curva de 
Spee apresentava-se notavelmente profunda em praticamente todos os casos do Grupo $1^{211}$.

BENNETT; MCLAUGHLIN²0, em 1990, afirmam que a utilização dos elásticos de Classe II associados às curvas reversas e acentuadas promovem extrusão no segmento póstero-inferior, e que no segmento ânterosuperior é neutralizada pela acentuação da curva ${ }^{20}$ e isso contribuiria sobremaneira para a correção da sobremordida, e o efeito dos arcos poderia se caracterizar por uma grande quantidade de indução e de restrição do crescimento alveolar, na região posterior e anterior, respectivamente.

\subsubsection{Correlações entre as variáveis}

Para analisar a correlação da reabsorção apical com os movimentos dentários e o tempo de tratamento, realizou-se o teste de correlação de Spearman (Tabela 10). Ao se correlacionar o tempo de tratamento considerou-se todos os incisivos superiores. No entanto, para correlação das alterações do trespasse horizontal e vertical, dos movimentos dos ápices e de inclinação foram considerados apenas os incisivos centrais, pois foram os dentes desenhados e marcados nos cefalogramas.

O tempo de tratamento não apresentou correlação com o grau de reabsorção (Tabela 11), concordando com outros trabalhos ${ }^{16,69,70,136,179,228}$.

Ocorreu correlação estatisticamente significante e positiva entre o grau de reabsorção radicular dos incisivos e a quantidade de trespasse vertical inicial (Tabela 9). Dessa forma, pode-se afirmar que uma maior reabsorção pode ocorrer quando casos apresentando essa característica sejam tratados com esta mecânica.

Outra correlação que se apresentou estatisticamente significante foi a do grau de reabsorção com a quantidade de correção do trespasse vertical, durante o tratamento. Pode-se então afirmar que quanto menor o trespasse vertical ao final tratamento, maior a reabsorção radicular dos incisivos. 
Esses resultados encontram-se de acordo com vários outros estudos na literatura, demonstrando mais uma vez que o movimento de intrusão pode ser considerado como fator de predição para as reabsorções, tanto nos casos sem $16,51,58,177$ como nos com extração ${ }^{16,38,94,95,177,205,206}$. A correção da mordida profunda demonstrou ser fator coadjuvante no processo de reabsorção radicular.

Os fatores que podem ter contribuído para essa maior quantidade de reabsorção são vários. Pode-se citar a necessidade de uma quantidade maior de força de intrusão e de tempo de uso da curva acentuada, pois procura-se corrigir inicialmente a sobremordida para após corrigir a sobressaliência. Também, o fato de que a acentuação da curva é ainda mantida para se evitar possíveis incrementos na sobremordida durante 0 processo de retração e há um incremento de torque vestibular incorporado aos fios retangulares pra evitar a lingualização das coroas dos incisivos. Deve-se associar o fato que, apesar do grau de retração ter sido semelhante entre os grupos, na Classe II há maior utilização de elásticos intermaxilares, e estes necessitam ainda de um maior torque e acentuação da curva de Spee incorporados aos fios, para contrapor aos efeitos indesejáveis que os mesmos proporcionam. Convém salientar que os elásticos ainda são removíveis, ou seja, em vários períodos do dia os dentes sofrem ações de forças diferentes, ora de intrusão e torque vestibular mais acentuado causado pelos fios quando o paciente está sem elásticos, ora de extrusão e distalização, quando o paciente os está utilizando. Essa força de intrusão maior, associada à retração e o maior torque no fio retangular impedindo os movimentos de inclinação e extrusão ocasiona uma grande pressão para o ápice dentário, o que promove o inicio do processo reabsortivo.

Também pode ocorrer que até à remoção do aparelho alguns novos períodos de intrusão e correção de torque ou mesmo o uso de elásticos de Classe II podem ser necessários para se alcançar um melhor acabamento e finalização do tratamento, consoante aos critérios estabelecidos de uma boa oclusão. Em outras palavras, movimentos sucessivos e intermitentes podem ter sido realizados, submetendo os dentes por mais tempo às forças ortodônticas e causando assim maior reabsorção, como proposto por KETCHAN ${ }^{118}$ (1927) e 
STUTEVILLE $^{224}$ (1938) há muito tempo ${ }^{14}$. Essa possibilidade na pesquisa em questão não pôde ser analisada, pois o material de estudo utilizado foi a documentação final do tratamento, e não em todas suas fases intermediárias.

MCFADDEN et al. ${ }^{150}$ sugeriram em 1989 um controle do tempo do tratamento mais rigoroso no intuito de se minimizar as reabsorções. Convém notar que em ambos os grupos, o tempo de tratamento foi similar. Talvez a velocidade com que a discrepância foi corrigida pode também ser um fator importante a ser considerado, pois no grupo onde a intrusão não era necessária e apenas a retração foi realizada, o tempo de tratamento não variou em relação ao grupo que possuía a mecânica de intrusão dos incisivos para a correção da sobremordida profunda adicionada ao tratamento. Isso leva à conclusão que essa quantidade de movimentação adicional que o grupo 1 necessitou para a correção dos trespasses não utilizou um tempo maior, mas sim uma quantidade maior de movimentação no mesmo período de tempo, e isso é conseguido com o uso de forças mais intensas e contínuas. Especulase, com o resultado encontrado, que um tempo de tratamento maior para os casos de sobressaliência e sobremordida com forças mais leves e intermitentes possa ser um atenuador da severidade da reabsorção na técnica, segundo cOSTOPOULOS; NANDA ${ }^{65}$ em 1996 e CONSOLARO ${ }^{58}$ em 2002.

\subsubsection{Comparação da reabsorção entre os incisivos}

Sabe-se, à saciedade, que os incisivos superiores são os dentes mais reabsorvidos durante o tratamento ${ }^{1,2,16,18,29,51,70,109,119,179,188}$. Especula-se que este resultado ocorra em razão da maior movimentação dos incisivos superiores, pois o espaço das extrações no arco inferior é utilizado mais para dissipação do apinhamento, que normalmente é maior nesse arco. Por esse motivo não houve preocupação em se avaliar, nos grupos, o arco inferior.

Entretanto, avaliou-se a ocorrência de graus diferenciados de reabsorção entre os incisivos centrais e laterais, pois a morfologia da raiz dentária representa um dos principais fatores na previsibilidade da ocorrência 
das reabsorções, durante a movimentação ortodôntica, para MIRABELLA; ARTUN $^{157}$, em 1995, CONSOLARO ${ }^{57}$, em 2002 e muitos outros ${ }^{120,141,206}$, e que os incisivos laterais superiores apresentam-se mais afetados, seguidos pelos incisivos centrais ${ }^{29,38,51,121,206,217}$. Nos incisivos laterais, devido a sua forma radicular mais estreita e à delicadeza da porção apical, geralmente com dilacerações, ocorre uma concentração maior de tensão no ápice culminando com as reabsorções ${ }^{16,57,148,177,196}$.

Nos resultados encontrados neste estudo, no grupo 2, os incisivos laterais apresentaram um grau médio de reabsorção maior que os centrais, porém no grupo 1 os resultados foram semelhantes, e em ambos os grupos as diferenças encontradas no grau de reabsorção entre os incisivos centrais e laterais não foram estatisticamente significantes (Tabela 11).

\subsection{Implicações Clínicas}

Este estudo demonstrou que, nos casos com intrusão, a reabsorção radicular apresentou-se maior (Tabela 6), com o maior percentual de reabsorção situado no grau 3 (41,96\% - Tabela 7). Apesar de apresentar uma incidência e quantidade de reabsorção aparentemente altas, mais da metade dos dentes avaliados apresentam reabsorção situados nos escores $1 \mathrm{e}$ 2, ou seja, de leve a moderado. Não obstante um grande número de dentes apresentar grau 3 de reabsorção, convém salientar que a perda do comprimento radicular não ultrapassou o terço apical da raiz não havendo, portanto, comprometimento do suporte dentário. Essas porcentagens tornamse aceitas diante do resultado do tratamento, da correção da má oclusão e da satisfação do paciente. Porém, antes de iniciar o tratamento, deve-se conscientizar o paciente sobre os riscos, e de forma clara, para que ele possa entender e assumir conjuntamente a responsabilidade dos resultados ${ }^{47}$.

Convém, ao início do tratamento, proceder a uma anamnese detalhada observando alguns fatores, como a gravidade da má oclusão ${ }^{95}$, presença de hábitos ${ }^{81,94,167,204}$, quantidade de uso de elásticos intermaxilares $^{136,157}$ e a severidade dos trespasses horizontal ${ }^{38,94,177,205,206}$ e 
vertical $^{58,155,177,186}$. Deve-se quantificar e qualificar esses fatores relacionandoos com outros, como doença periodontal, má colaboração do paciente, características anatômicas dos dentes e das cristas alveolares, traumas previamente existentes e outros que possam influenciar negativamente a integridade radicular, ao final do tratamento ${ }^{47,58}$. Assim, deve-se compatibilizar as forças e movimentos necessários de acordo com os dados encontrados, prevendo uma maior probabilidade de reabsorção.

Também, planejar movimentações menos extensas, instituir as extrações quando estritamente necessárias, manter controle adequado de ancoragem, minimizar a necessidade de uso dos elásticos intermaxilares e utilizar técnicas de correção da sobremordida reconhecidamente menos lesivas, que mesclem o movimento de extrusão posterior para a correção, como o uso de placas de levantamento ou de "Bite Ramps" que promovam a extrusão dos posteriores, quando possível.

Nenhuma mecânica ortodôntica, por mais brandas que sejam as forças exercidas, estará livre de desencadear um processo de reabsorção ${ }^{175}$. Entretanto, não é a quantidade de força aplicada a principal causa da reabsorção, mas sim a sua distribuição. No caso de dentes submetidos à retração e intrusão, deve-se manter um controle bastante rigoroso da mecânica, com forças leves e controladas. Não convém caracterizar um possível aumento da sobremordida durante a retração como uma falha técnica no controle da mecânica, que deva ser corrigido imediatamente com maior força e velocidade para não afetar o processo de retração. Deve-se sim, encará-lo como um efeito indesejável, porém aceitável, que deve ser corrigido lentamente, como a técnica preconiza, aliviando-se a mecânica retrusiva para em seguida dar continuidade a esse processo com as forças adequadas. Avaliar e compatibilizar a intensidade, a direção e o tempo de ação das forças sobre os dentes mantendo uma efetiva movimentação dentária com um mínimo de dano tecidual implica indispensável conhecimento e habilidade das técnicas ortodônticas.

Sem a menção de mecânicas específicas, o tratamento ortodôntico em geral pode provocar reabsorção discreta e pouco significante na maioria 
dos pacientes $(<0,9 \mathrm{~mm})$ e poderá será agressiva $(>3 \mathrm{~mm})$ em $10 \%$ deles $^{137}$. Portanto, idealmente deve-se radiografar os dentes 6 meses após o início do tratamento com radiografias periapicais e, ao se constatar reabsorção num grau 2 ou 3, recomenda-se uma pausa de 60 a 90 dias no tratamento para depois ser reiniciado com forças leves e intermitentes, ou até mesmo sua interrupção definitiva ${ }^{47,58,130}$. A reabsorção causada pelo tratamento ortodôntico cessa após uma semana da suspensão das forças, e ocorre uma regularização da superfície afetada durante o segundo mês de descanso. Convém lembrar que a raíz encurtada pela reabsorção é mais propensa à reabsorver, pois a proporção coroa/raiz será maior, levando mais força para o ápice, gerando um ciclo desfavorável ${ }^{58}$.

Mesmo que a literatura ateste que a reabsorção radicular provocada durante o tratamento cessa quando a força é eliminada $16,29,35,36,130,136,144,175,197$, deve-se tomar cuidado com os pacientes que ao final do tratamento apresentem hábitos parafuncionais ou algum contato prematuro $^{58,94,171,172}$, pois assim estarão perpetuando a ação das forças sobre os dentes, continuando a reabsorção.

Dessa forma, uma simples placa de Hawley bem adaptada ou ajuste oclusal não resolverão definitivamente o problema devendo-se, em casos com bruxismo ou apertamento, por exemplo, instituir o uso de placas miorrelaxantes. Contenções ativas, sobre um dente ou um grupo de dentes, também podem manter o processo de reabsorção ${ }^{58,71}$. De qualquer modo, o tratamento bem finalizado com os dentes em posição estável, mantidos temporariamente por uma contenção passiva, apresentam perspectiva segura de interrupção da reabsorção, proporcionando longevidade a esses dentes. 


\subsection{Sugestões para novos trabalhos}

- Analisar, na mesma amostra deste estudo, medidas cefalométricas relativas ao crescimento maxilofacial e alveolar imposto pela técnica de correção da sobremordida profunda, como coadjuvante ou principal corretor da má oclusão, explicitando e quantificando essas alterações, comparando-as com um grupo controle não tratado nessa mesma faixa etária.

- Verificar e quantificar a participação das extrações seguidas da mecânica de retração anterior sobre o grau de reabsorção radicular em casos apresentando sobremordida profunda tratados com intrusão, com amostras perfeitamente compatíveis.

- Comparar o grau de reabsorção de pacientes com mordida aberta, tratados com e sem extração, com pacientes com trespasse vertical normal, tratados com e sem extração e com trespasse vertical acentuado, com e sem extração, todos entre si avaliando e ordenando todas as mecânicas por graus de severidade de reabsorção.

- Pesquisar numa amostra apenas de pacientes adultos, portanto sem a influência do crescimento, o deslocamento vertical nos movimentos intrusivos do ápice dentário correlacionando-os aos processos de reabsorção, incluindo os caninos na pesquisa.

- Avaliar se o uso do "Bite Ramp", dispositivo fixo colado nas faces palatinas dos incisivos superiores, com o fito de auxílio na abertura da mordida, pode ser uma alternativa menos lesiva para a correção nos casos onde haja sua indicação, visto corrigir a sobremordida em um curto período, minimizando o tempo e a quantidade do movimento intrusivo. Ou se o contrário é verdadeiro, causando morte de cementoblastos dos referidos dentes na fase inicial, propiciando maiores reabsorções ao final dos tratamentos. 
Conclusões 


\section{7 - CONCLUSÕES}

om base na metodologia empregada e nos resultados obtidos,
pode-se concluir que:

1. Os graus de reabsorções radiculares apresentaram-se diferentes para os grupos avaliados, manifestando-se maior no grupo em que foi realizado o movimento conjugado de intrusão com retração, com grau médio de reabsorção de 2,375, ao passo que o grupo com retração apresentou a mesma com grau médio de 1,696;

2. A mecânica combinada apresentou uma ação consideravelmente mais lesiva sobre os ápices, com $41,96 \%$ das raízes apresentando encurtamento radicular próximo ao limite do terço apical. Já o movimento de retração foi responsável por esse grau de encurtamento em apenas 9,82\% dos dentes.

3. Correlacionando as reabsorções com as variáveis pesquisadas em ambos os grupos, pode-se concluir que:

a. Não ocorreu correlação com o tempo de tratamento em nenhum dos grupos.

b. Verificou-se correlação positiva da reabsorção com a quantidade inicial de sobremordida apresentada, ou seja, quanto maior o trespasse vertical apresentado ao inicio do tratamento, mais reabsorção se pode esperar ao final da correção.

c. Em relação à quantidade de correção, quanto mais se corrige o trespasse vertical utilizando-se a mecânica conjugada, maior o grau de reabsorção radicular ao final do tratamento. O mesmo já é esperado mesmo nos casos sem intrusão, apenas com retração, porém em menor quantidade. A movimentação dos ápices e a inclinação dentária não apresentaram correlação significante.

4. Ocorreu diferença na quantidade de reabsorção apresentada entre os diferentes dentes, comprometendo os incisivos laterais em maior magnitude que os centrais, porém estatisticamente não significante.

5. A conjugação da mecânica de intrusão com a de retração constitui um fator clinicamente relevante na predição da reabsorção radicular. 


\section{Referências}

Bibliográficas 


\section{8 - REFERÊNCIAS BIBLIOGRÁFICAS}

1. AHLGREN, J. A ten-year evaluation of the quality of orthodontic treatment. Swed Dent J, v. 17, n. 5, p. 201-9, 1993.

2. ALEXANDER, S.A. Levels of root resorption associated with continuous arch and sectional arch mechanics. Am J Orthod Dentofacial Orthop, v. 110, n. 3, p. 321-4, Sep. 1996.

3. ALMEIDA, R.R. et al. Reabsorção radicular idiopática: relato de um caso clínico. Rev Dent Press Ortodont Ortoped Facial, v. 4, n. 5, p. 35-40, set./out. 1999.

4. ALMEIDA, R.R. et al. Mordida aberta anterior: Considerações e apresentação de um caso clínico. Rev Dent Press Ortodont Ortoped Facial, v. 3, n. 2, p. 17-29, Mar-Abr. 1998.

5. ALQABANDI, A.K.; SADOWSKY, C.; BEGOLE, E.A. A comparison of the effects of rectangular and round arch wires in leveling the curve of Spee. Am J Orthod Dentofacial Orthop, v. 116, n. 5, p. 522-9, Nov. 1999.

6. AL-QAWASMI, R.A. et al. Genetic predisposition to external apical root resorption. Am J Orthod Dentofacial Orthop, v. 123, n. 3, p. 242-52, Mar. 2003.

7. ALVARES, L.C.; TAVANO, O. Curso de radiologia em Odontologia. In: SANTOS E. Técnicas radiográficas. São Paulo: 2; 1990. p. 51-117.

8. ANDREASEN, J.O. External root resorption: its implication in dental traumatology, paedodontics, periodontics, orthodontics and endodontics. Int Endod J, v. 18, n. 2, p. 109-18, Apr. 1985.

9. ARNESEN, F.A. Avaliação da reabsorção radicular externa, consecutiva ao tratamento ortodôntico Piracicaba, 1984. 91p. Dissertação (Mestrado em Ortodontia) - Faculdade de Odontologia de Piracicaba, Universidade Estadual de Campinas.

10. ARVYSTAS, M.G. Nonextration treatment of Class II division 1 malocclusions. Am J Orthod, v. 88, n. 5, p. 380-95, Nov. 1985.

11. BARBOSA, J.A. Estudo cefalométrico longitudinal do crescimento anterior da face, relacionado com a sobremordida, em adolescentes, brasileiros, leucodermas, com "oclusão normal" Bauru, 1978. 63p. Dissertação (Mestrado) - Universidade de São Paulo.

12. BATES, S. Absorption. Br J Dent, v. 1, n., p. 256, 1856.

13. BAUMANN, W.R.G.; TAVARES, D. Reabsorções dentais causadas pelo tratamento. Rev Gaúcha Odontol, v. 36, n. 2, p. 91-6, mar./abr. 1988.

14. BAUMRIND, S.; KORN, E.L.; BOYD, R.L. Apical root resorption in orthodontically treated adults. Am J Orthod Dentofacial Orthop, v. 110, n. 3, p. 311-20, Sep. 1996. 
15. BAYDAS, B. et al. Investigation of the changes in the positions of upper and lower incisors, overjet, overbite, and irregularity index in subjects with different depths of curve of Spee. Angle Orthod, v. 74, n. 3, p. 349-55, Jun. 2004.

16. BECK, B.W.; HARRIS, E.F. Apical root resorption in orthodontically treated subjects: analysis of edgewise and light wire mechanics. Am J Orthod Dentofacial Orthop, v. 105, n. 4, p. 350-61, Apr. 1994.

17. BELANGER, G.K.; COKE, J.M. Idiopathic external root resorption of the entire permanent dentition: report of case. ASDC J Dent Child, v. 52, n. 5, p. 359-63, Sep-Oct. 1985.

18. BELTRÃO, R.T. Estudo da reabsorção radicular dos incisivos, após o tratamento da mordida aberta anterior Bauru, 2005. 144pp. Tese (Doutorado) - Universidade de São Paulo.

19. BENNETT, J.C.; MACLAUGHLIN, R.P. As mecânicas do tratamento ortodôntico e o aparelhos pré-ajustado: Artes Médicas, 1997.

20. BENNETT, J.C.; MCLAUGHLIN, R.P. Management of deep overbite with a preadjusted appliance system. J Clin Orthod, v. 24, n. 11, p. 684-96, Nov. 1990.

21. BERGENSEN, E.O. A longitudianl study of anterior vertical overbite from eight to twenty years of age. Angle Orthod, v. 58, n. 3, p. 237-56, July. 1988.

22. BIGGERSTAFF, R.H.; PHILLIPS, J.R. A quantitative comparison of paralleling long-cone and bisection-of-angle periapical radiography. Oral Surg, v. 41, n. 5, p. 673-7, May. 1976.

23. BISHARA, S.E. Ortodontia. São Paulo: Livraria Santos, c2004.

24. BISHARA, S.E.; CUMMINS, D.M.; JAKOBSEN, J.R. The morphologic basis for the extraction decision in Class II, division 1 malocclusions: a comparative study. Am J Orthod Dentofacial Orthop, v. 107, n. 2, p. 129-35, Feb. 1995.

25. BISHARA, S.E.; TREDER, J.E.; JAKOBSEN, J.R. Facial and dental changes in adulthood. Am J Orthod Dentofacial Orthop, v. 106, n. 2, p. 17586, Aug. 1994.

26. BISHARA, S.E.; VONWALD, L.; JAKOBSEN, J.R. Changes in root length from early to mid-adulthood: resorption or apposition? Am J Orthod Dentofacial Orthop, v. 115, n. 5, p. 563-8, May. 1999.

27. BJÖRK, A. Prediction of mandibular growth rotation. Am J Orthod, v. 55, n. 6, p. 585-99, June. 1969.

28. BJÖRK, A. Variability and ages changes in overjet and overbite. Am J Orthod, v. 39, n. 10, p. 779-801, Oct. 1953.

29. BLAKE, M.; WOODSIDE, D.G.; PHAROAH, M.J. A radiographic comparison of apical root resorption after orthodontic treatment with the edgewise and Speed appliances. Am J Orthod Dentofacial Orthop, v. 108, n. 1, p. 76-84, Jul. 1995. 
30. BRAUN, S. Achieving improved visualization of the temporomandibular joint condyle and fossa in the sagittal cephalogram and a pilot study of their relationships in habitual occlusion. Am J Orthod Dentofacial Orthop, v. 109, n. 6, p. 635-8, Jun. 1996.

31. BRAUN, S.; HNAT, W.P.; JOHNSON, B.E. The curve of Spee revisited. Am J Orthod Dentofacial Orthop, v. 110, n. 2, p. 206 - 210, Aug. 1996.

32. BREZNIAK, N. et al. The use of an individual jig in measuring tooth length changes. Angle Orthod, v. 74, n. 6, p. 780-5, Dec. 2004.

33. BREZNIAK, N. et al. The accuracy of the cementoenamel junction identification on periapical films. Angle Orthod, v. 74, n. 4, p. 496-500, Aug. 2004.

34. BREZNIAK, N. et al. The use of an individual jig in measuring tooth lenght changes. Angle Orthod, v. 74, n. 4, p. 778-783, Oct. 2004.

35. BREZNIAK, N.; WASSERSTEIN, A. Root resorption after orthodontic treatment: Part 1. Literature review. Am J Orthod Dentofacial Orthop, v. 103, n. 1, p. 62-6, Jan. 1993.

36. BREZNIAK, N.; WASSERSTEIN, A. Root resorption after orthodontic treatment: Part 2. Literature review. Am J Orthod Dentofacial Orthop, v. 103, n. 2, p. 138-46, Feb. 1993.

37. BRIN, I.; BECKER, A.; ZILBERMAN, Y. Resorbed lateral incisors adjacent to impacted canines have normal crown size. Am J Orthod Dentofacial Orthop, v. 104, n. 1, p. 60-6, July. 1993.

38. BRIN, I. et al. External apical root resorption in Class II malocclusion: a retrospective review of 1 - versus 2-phase treatment. Am J Orthod Dentofacial Orthop, v. 124, n. 2, p. 151-6, Aug. 2003.

39. BROOKS, I.K. An unusual case of idiopathic internal root resorption beginning in an unerupted permanent tooth. J. Endod., v. 12, n. 7, p. 309-10, july. 1986.

40. BRUSOLA, J.A.C.; AL., E. Ortodoncia clinica. Barcelona.: Salvat Editores, 1989.

41. BURSTONE, C.R. Deep overbite correction by intrusion. Am J Orthod, v. 72, n. 1, p. 1-22, July. 1977.

42. CAMBI, A. et al. Correlaçäo entre a reabsorçäo radicular e os movimentos ortodônticos de intrusäo e torque. Ortodontia, v. 35, n. 2, p. 121-9, abr./jun. 2002.

43. CANSANÇÃO, J.M. Avaliação radiográfica da reabsorção radicular, consecutiva ao tratamento ortodôntico, pela técnica do arco de canto, relacionada com o sexo, a idade, a duração do tratamento, o período de uso do arco retangular e do aparelho extrabucal. Bauru, 1980. 68p. Dissertação (Mestrado) - Universidade de São Paulo.

44. CANSANÇÄO, J.M.; MARTINS, D.R. Avaliação radiográfica da reabsorção radicular, consecutiva ao tratamento ortodôntico, pela técnica do 
arco de canto, relacionada com o sexo, a idade, a duração do tratamento, o período de uso do arco retangular e do aparelho extrabucal. Ortodontia, v. 14, n. 2, p. 84-96, maio/ago. 1981.

45. CANTO, G.L. Estudo comparativo da reabsorção radicular apical, decorrente do tratamento ortodôntico, em pacientes tratados com a técnica do Arco de Canto Simplificada, do Arco Reto e com a Terapia Bauru, 1997. 162 pp. Dissertação (Mestrado) - Faculdade de Odontologia de Bauru, Universidade de São Paulo.

46. CAPELOZZA, L. et al. Reabsorção radicular na clínica ortodôntica: aplicação de um método radiográfico para diagnóstico precoce. Ortodontia, v. 35, n. 2, p. 14-26, abr.-jun. 2002.

47. CAPELOZZA, L.; SILVA FILHO, O. Reabsorção radicular na clínica ortodôntica: atitudes para uma conduta preventiva. Rev Dental Press Ortodo Ortop Facial, v. 3, n. 1, p. 104-26, 1998.

48. CASSIDY JR., D.W. et al. A comparison of surgery and orthodontics in "borderline" adults with Class II, Division 1 malocclusions. Am J Orthod Dentofacial Orthop, v. 104, n. 5, p. 455-70, Nov. 1993.

49. CEYLAN, I.; ERÖZ, Ü.B. The effects of overbite on the maxillary and mandibular morphology. Angle Orthod, v. 71, n. 2, p. 110-5, Apr. 2001.

50. CHAN, E.K.M.; DARENDELILER, M.A. Exploring the third dimension in root resorption. Orthod Craniofacial Res, v. 7, n. 2, p. 64-70, May. 2004.

51. CHIQUETO, K.F.G. Influência da mecânica intrusiva de acentuação e reversão da curva de spee, no grau de reabsorção radicular. Bauru, 2005. 113p. Mestrado em Ortodontia - Universidade de São Paulo.

52. CHO, M.I.; LIN, W.L.; GARANT, P.L. Occurrence of epidermal growth factor-binding sites during differentiation of cementoblasts and periodontal ligament fibroblasts of young rat: a light and electron microscopic radioautographic study. Ant. Rec., v. 231, n. 1, p. 14-24, sept. 1991. 1991.

53. CHOY, K. et al. Effect of root and bone morphology on the stress distribution in the periodontal ligament. Am J Orthod Dentofacial Orthop, v. 117, n. 1, p. 98-105, Jan. 2000.

54. CLIFFORD, P.M.; ORR, J.F.; BURDEN, D.J. The effects of increasing the reverse curve of Spee in a lower archwire examined using a dynamic photoelastic gelatine model. Eur J Orthod, v. 21, n. 3, p. 213-22, June. 1999.

55. CONSOLARO, A. O primeiro estudo sobre hereditariedade relacionada com as reabsorções dentárias em Ortodontia: uma análise crítica do trabalho de Newman. R Dent Press Ortodon Ortop Facial, v. 9, n. 2, p. 110-122, mar./abr. 2004.

56. CONSOLARO, A. Parcial anodontia: form and size of remaining teeth and orthodontics implications. In: ANNUAL SESSION OF THE AMERICAN ASSOCIATION OF ORTHODONTICS, 101., 2001. Toronto. Annals... Toronto: American Association of Orthodontics, v. n., p. 84, 2001. 
57. CONSOLARO, A. Reabsorções dentárias na movimentação ortodôntica. In: PRESS D. Reabsorções dentárias nas especialidades clínicas. Maringá: Consolaro, A.; 2002. p. 259-89.

58. CONSOLARO, A. Reabsorções dentárias nas especialidades clínicas. Maringá: Editora Dental Press, 2002.

59. CONSOLARO, A. Sobre alguns aspetos metodológicos de pesquisas em movimentação dentária induzida e das reabsorções dentárias: uma proposta guia e cuidados para análise de trabalhos. R Dent Press Ortodon Ortop Facial, v. 9, n. 2, p. 104-109, mar./abr. 2004.

60. CONSOLARO, A. et al. Conceitos da genética e hereditariedade aplicados à compreensão das reabsorções dentárias durante a movimentação ortodôntica. Rev Dental Press Ortodo Ortop Facial, v. 9, n. 2, p. 79-94, mar/abr. 2004.

61. CONSOLARO, A.; MARTINS-ORTIZ, M.F. Em busca de uma causa à parte da ortodontia: Hereditariedade e reabsorção apical em pacientes tratados ortodonticamente. Uma análise crítica do trabalho de Harris, Kineret e Tolley. Rev Dental Press Ortodo Ortop Facial, v. 9, n. 2, p. 123-135, mar/abr. 2004.

62. CONSOLARO, A.; MARTINS-ORTIZ, M.F. Hereditariedade e suscetibilidade à reabsorção radicular em Ortodontia não se fundamentam: erros metodológicos e interpretativos repetidamente publicados podem gerar falsas verdades. Análise crítica do trabalho de Al-Qawasmi et al. sobre a predisposição genética à reabsorção radicular de natureza ortodôntica. $\mathbf{R}$ Dent Press Ortodon Ortop Facial, v. 9, n. 2, p. 146-157, mar./abr. 2004.

63. CONSOLARO, A.; MARTINS-ORTIZ, M.F. Predisposição genética, hereditariedade e reabsorções radiculares em Ortodontia. Cuidados com interpretações precipitadas: uma análise crítica do trabalho de Al-Qawasmi, et al. R Dent Press Ortodon Ortop Facial, v. 9, n. 2, p. 136-145, mar./abr. 2004.

64. COPELAND, S.; GREEN, L.J. Root resorption in maxillary central incisors following active orthodontic treatment. Am J Orthod, v. 89, n. 1, p. 515, Jan. 1986.

65. COSTOPOULOS, G.; NANDA, R. An evaluation of root resorption incident to orthodontic intrusion. Am J Orthod Dentofacial Orthop, v. 109, n. 5, p. 543-8, May. 1996.

66. CREEKMORE, T.D. Inhibition or stimulation of the vertical growth of the facial complex, its significance to treatment. Angle Orthod, v. 37, n. 4, p. 28597, Oct. 1967.

67. DAHLBERG, G. Statistical methods for medical and biological students. New York: Intercience Publications, 1940.

68. DAWSON, P.E. Avaliação, diagnóstico e tratamento dos problemas oclusais. 2 ed. Rio de Janeiro: Artes Médicas, 1993.

69. DERMAUT, L.R.; DE MUNCK, A. Apical root resorption of upper incisors caused by intrusive tooth movement: a radiographic study. Am J Orthod Dentofacial Orthop, v. 90, n. 4, p. 321-6, Oct. 1986. 
70. DESHIELDS, R.W. A study of root resorption in treated Class II, division 1 malocclusions. Angle Orthod, v. 39, n. 4, p. 231-45, Oct. 1969.

71. DOUGHERTY, H.L. The effect of mechanical forces upon the mandibular buccal segments during orthodontic treatment. Am J Orthod, v. 54, n. 1, p. 2949, Jan. 1968.

72. DOWNS, W.B. Variations in facial relationships: their significance in treatment and prognosis. Am J Orthod, v. 34, n. 10, p. 812-40, Oct. 1948.

73. ELLIS, E., 3RD; MCNAMARA, J.A., JR.; LAWRENCE, T.M. Components of adult Class II open-bite malocclusion. J Oral Maxillofac Surg, v. 43, n. 2, p. 92-105, Feb. 1985.

74. ENGEL, G. et al. Treatment of deep-bite cases. Am J Orthod, v. 77, n. 1, p. 1-13, Jan. 1980.

75. ERICSON, S.; KUROL, J. Radiographc examination of ectopically erupting maxillary canines. Am J Orthod Dentofacial Orthop, v. 91, n. 6, p. 483-92, June. 1987.

76. ERICSON, S.; KUROL, J. Resorption of maxillary lateral incisors caused by ectopic eruption of canines. Am J Orthod Dentofacial Orthop, v. 94, n. 6, p. 503-13, Dec. 1988.

77. FERGUSON, J.W. Lower incisor torque: the effects of rectangular archwires with a reverse curve of Spee. Br J Orthod, v. 17, n. 4, p. 311-5, Nov. 1990.

78. FLEISS, J.L. Statistical methods for rates and proportions. New York: . John Wiley \& Sons, 1973.

79. FLEMING, H.B. An investigation of the vertical overbite during the eruption of the permanent dentition. Angle Orthod, v. 31, n. 1, p. 53-62, Jan. 1961.

80. FRANCISCHONE, T.R.C.G. Reabsorção dentária: determinação de sua freqüência em pacientes com endocrinopatias. Bauru, 2002. 125p. Tese (Doutorado) - Universidade de São Paulo.

81. FRANTZ, D.W. Apical root resorption in the anterior open bite malocclusion Washington, 1965Master of Science in Dentistry - University of Washington.

82. FREITAS, M.R. et al. Long-term stability of anterior open bite extraction treatment in the permanent dentition. Am J Orthod Dentofacial Orthop, v. 125, n. 1, p. 78-87, Jan. 2004.

83. FURQUIM, L.Z. Perfil endocrinológico de pacientes ortodônticos com e sem reabsorções dentárias: correlação com a morfologia radicular e da crista óssea alveolar. Bauru, 2002. 122p. Tese (Doutorado) Universidade de São Paulo.

84. GARCIA, R. Leveling the curve of Spee: a new prediction formula. J Charles H Tweed Int Found, v. 13, n., p. 65-72, Apr. 1985. 
85. GEBECK, T.R.; MERRIFIELD, L.L. Orthodontic diagnosis and treatment analysis--concepts and values. Part I. Am J Orthod Dentofacial Orthop, v. 107, n. 4, p. 434-43, Apr. 1995.

86. GOAZ, P.W.; WHITE, S.C. Intraoral radiographic examination. In: MOSBY. Oral radiology. Principles and interpretation. Saint Louis: 3; 1994. p. 151-218.

87. GOLDIN, B. Labial root torque: effect on the maxilla and incisor root apex. Am J Orthod Dentofacial Orthop, v. 95, n. 3, p. 208-19, Mar. 1989.

88. GONDIM, P.P.C. et al. Estudo cefalométrico longitudinal do desenvolvimento da sobremordida em jovens leucodermas brasileiros dos 6 aos 18 anos. R Dent Press Ortodon Ortop Facial, v. 6, n. 4, p. 7-17, jul./ago. 2001.

89. GRABER, T. Orthodontics: principles and practice. 3rd ed, 1972.

90. GRIEVE, G.W. The most difficult problem in orthodontic - the elimination of deep overbite - Young. Dent Cosmos, v. 70, n. 4, p. 704-7, Oct. 1928.

91. HALAZONETIS, D.J.; ABELSON, M.N. Digital image processing: how to retouch your clinical photographs. Am J Orthod Dentofacial Orthop, v. 118, n. 4, p. 469-75, Oct. 2000.

92. HARRIS, E.F.; BAKER, W.C. Loss of root length and crestal bone height before and during treatment in adolescent and adult orthodontic patients. Am J Orthod Dentofacial Orthop, v. 98, n. 5, p. 463-9, Nov. 1990.

93. HARRIS, E.F.; BOGGAN, B.W.; WHEELER, D.A. Apical root resorption in patients treated with comprehensive orthodontics. J Tenn Dent Assoc, v. 81, n. 1, p. 30-3, Winter. 2001.

94. HARRIS, E.F.; BUTLER, M.L. Patterns of incisor root resorption before and after orthodontic correction in cases with anterior open bites. Am J Orthod Dentofacial Orthop, v. 101, n. 2, p. 112-9, Feb. 1992.

95. HARRIS, E.F.; KINERET, S.E.; TOLLEY, E.A. A heritable component for external apical root resorption in patients treated orthodontically. Am J Orthod Dentofacial Orthop, v. 111, n. 3, p. 301-9, Mar. 1997.

96. HARRIS, E.F.; ROBINSON, Q.C.; WOODS, M.A. An analysis of causes of apical root resorption in patients not treated orthodontically. Quintessence Int, v. 24, n. 6, p. 417-28, June. 1993.

97. HARRY, M.R.; SIMS, M.R. Root resorption in bicuspid intrusion. A scanning electron microscope study. Angle Orthod, v. 52, n. 3, p. 235-58, July. 1982.

98. HARTSFIELD JR, J.; EVERETT, E.; AL-QAWASMI, R. Genetic factors in external apical root resorption and orthodontic treatment. Crit Rev Oral Biol Med, v. 15, n. 2, p. 115-122, 2004.

99. HAYNES, S. The distribution of overjet and overbite in English children aged 11-12 years. Dent Pract, v. 22, n. 10, p. 380-3, June. 1972. 
100. HEMELEY, S. The incidence of root resorption of vital permanent teeth. $\mathbf{J}$ Dent Res, v. 20, n., p. 133-41, 1941.

101. HENDRIX, I. et al. A radiographic study of posterior apical root resorption in orthodontic patients. Am J Orthod Dentofacial Orthop, v. 105, n. 4, p. 3459, Apr. 1994.

102. HENRY, J.L.; WEINMAN, J.P. The pattern of resorption and repair of human cement. J Amer Dent Assoc, v. 42, n., p. 270-290, 1951.

103. HERNESS, L.E.; RULE, J.T.; WILLIAMS, B.H. A longitudinal cephalometric study of incisor overbite from ages five to eleven. Angle Orthod, v. 43 , n. 3 , p. $279-88$, July. 1973.

104. HIDALGO, M.M. Estudo sobre o potencial imunogênico da dentina contribuição para a etiopatogenia da reabsorção dentária. Bauru, 2001. 103p. Tese de Doutorado - Universidade de São Paulo.

105. HORIUCHI, A.; HOTOKEZAKA, H.; KOBAYASHI, K. Correlation between cortical plate proximity and apical root resorption. Am J Orthod Dentofacial Orthop, v. 114, n. 3, p. 311-8, Sep. 1998.

106. HOUSTON, W.J. The analysis of errors in orthodontic measurements. Am J Orthod, v. 83, n. 5, p. 382-90, May. 1983.

107. INTERLANDI, S. Sobremordidas profundas. Incidência, proposição de uma classificação, revisão da etiologia e mecanismos biogenéticos. Rev Ass Paul Cirurg Dent, v. 14, n. 5, p. 241-9, set./out. 1960.

108. JACOBSON, A. The "Wits" appraisal of jaw disharmony. Am J Orthod, v. 67, n. 2, p. 125-38, Feb. 1975.

109. JANSON, G. et al. A radiographic comparison of apical root resorption after orthodontic treatment with 3 different fixed appliance techniques. Am $\mathbf{J}$ Orthod Dentofacial Orthop, v. 118, n. 3, p. 262-73, Sep. 2000.

110. JANSON, G.; METAXAS, A.; WOODSIDE, D.G. Variation in maxillary and mandibular molar and incisor vertical dimension in 12-year-old subjects with excess, normal, and short lower anterior face height. Am J Orthod Dentofacial Orthop, v. 106, n. 4, p. 409-18, Oct. 1994.

111. JANSON, G. et al. Stability of anterior open bite nonextraction treatment in the permanent dentition. Am J Orthod Dentofacial Orthop, v. 124, n. 3, p. 265-76; quiz 340, Sep. 2003.

112. JARABAK, J.R. Development of a treatment plan in the light of one's concept of treatment objectives. Amer. J. Orthodont., v. 46, n. 7, p. 481-514, July. 1960.

113. JIANG, R.P.; ZHANG, D.; FU, M.K. A factors study of root resorption after orthodontic treatment]. Zhonghua Kou Qiang Yi Xue Za Zhi, v. 38, n. 6, p. 455-7, Nov. 2003.

114. KAFFE, I. et al. A radiographic survey of apical root resorption in pulpless permanent teeth. Oral Surg, v. 58, n. 1, p. 109-12, July. 1984. 
115. KALEY, J.; PHILLIPS, C. Factors related to root resorption in edgewise practice. Angle Orthod, v. 61, n. 2, p. 125-32, Summer. 1991.

116. KAWAUCHI, M.Y. et al. Avaliação cefalométrica longitudinal do posicionamento dentário e da rotação mandibular, em pacientes com sobremordida profunda, tratados com extrações dos quatro primeiros prémolares. Parte 1 - Tratamento da sobremordida profunda. Ortodontia, v. 30, n. 3, p. 31-9, set./dez. 1997.

117. KENNEDY, D.B. et al. The effect of extraction and orthodontic treatment on dentoalveolar support. Am J Orthod, v. 84, n. 3, p. 183-90, Sept. 1983.

118. KETCHAM, A.H. A preliminary report of investigation of apical root resorption of permanent teeth. Int J Orthodont Oral Surg and Radiog, v. 13, n. 2, p. 97-127, Feb. 1927.

119. KETCHAM, A.H. A radiographic study of orthodontic tooth movement; a preliminary report. J. Am. Dent. Ass., v. 14, n. 9, p. 1577-1588, Sep. 1927.

120. KJAER, I. Morphological characteristics of dentitions developing excessive root resorption during orthodontic treatment. Eur J Orthod, v. 17, n. 1, p. 25-34, Feb. 1995.

121. KOOK, Y.A.; PARK, S.; SAMESHIMA, G.T. Peg-shaped and small lateral incisors not at higher risk for root resorption. Am J Orthod Dentofacial Orthop, v. 123 , n. 3, p. 253-8, Mar. 2003.

122. KROGMAN, W.M. Craniometry and cephalometry as research tools in growth of head and face. Am J Orthod, v. 37, n. 6, p. 406-14, Jun. 1951.

123. KROGMAN, W.M.; SASSOUNI, V. A syllabus in roentgenographic cephalometry: Philadelphia center for research in child growth. Philadelphia, 1957.

124. KUCUKKELES, N. et al. Cephalometric evaluation of open bite treatment with NiTi arch wires and anterior elastics. Am J Orthod Dentofacial Orthop, v. 116, n. 5, p. 555-62, Nov. 1999.

125. KUPERSTEIN, R. External apical root resorption of the maxillary central incisor in anterior open bite malocclusion Portland, Oregon, 2004. 54p. Master of Science in Orthodontics - Oregon Health and Science University School of Dentistry.

126. LANDIS, J.R.; KOCH, G.G. An application of hierarchical kappa-type statistics in the assessment of majority agreement among multiple observers. Biometrics, v. 33, n. 2, p. 363-74, Jun. 1977.

127. LANGLAIS, R.P.; LANGLAND, O.E.; NORTJÉ, C.J. Influence of orthodontic treatment on root development of premolars. In: WILKINS W. Diagnostic imaging of the jaws. Baltimore; 1995. p. 1-17.

128. LEACH, H.A.; IRELAND, A.J.; WHAITES, E.J. Radiographic diagnosis of root resorption in relation to orthodontics. Br Dent J, v. 190, n. 1, p. 16-22, Jan. 2001. 
129. LEE, R.Y.; ARTUN, J.; ALONZO, T.A. Are dental anomalies risk factors for apical root resorption in orthodontic patients? Am J Orthod Dentofacial Orthop, v. 116, n. 2, p. 187-95, Aug. 1999.

130. LEVANDER, E.; MALMGREN, O. Evaluation of the risk of root resorption during orthodontic treatment: a study of upper incisors. Eur J Orthod, v. 10, n. 1, p. 30-8, Feb. 1988.

131. LEVANDER, E.; MALMGREN, O.; ELIASSON, S. Evaluation of root resorption in relation to two orthodontic treatment regimes. A clinical experimental study. Eur J Orthod, v. 16, n. 3, p. 223-8, Jun. 1994.

132. LEVANDER, E.; MALMGREN, O.; STENBACK, K. Apical root resorption during orthodontic treatment of patients with multiple aplasia: a study of maxillary incisors. Eur J Orthod, v. 20, n. 4, p. 427-34, Aug. 1998.

133. LEW, K. Intrusion and apical resorption of mandibular incisors in Begg treatment: anchorage bend or curve? Aust Orthod J, v. 11, n. 3, p. 164-8, Mar. 1990.

134. LEWIS, P. Correction of deep anterior overbite. Am J Orthod Dentofacial Orthop, v. 91, n. 4, p. 342-45, Apr. 1987.

135. LIGTHELM-BAKKER, A.S. et al. Vertical growth of the anterior face: a new approach. Am J Orthod Dentofacial Orthop, v. 101, n. 6, p. 509-13, Jun. 1992.

136. LINGE, B.O.; LINGE, L. Apical root resorption in upper anterior teeth. Eur J Orthod, v. 5, n. 3, p. 173-83, Aug. 1983.

137. LINGE, L.; LINGE, B.O. Patient characteristics and treatment variables associated with apical root resorption during orthodontic treatment. Am $\mathbf{J}$ Orthod Dentofacial Orthop, v. 99, n. 1, p. 35-43, Jan. 1991.

138. LUPI, J.E.; HANDELMAN, C.S.; SADOWSKY, C. Prevalence and severity of apical root resorption and alveolar bone loss in orthodontically treated adults. Am J Orthod Dentofacial Orthop, v. 109, n. 1, p. 28-37, Jan. 1996.

139. MACHADO, A.W.; SOUKI, B.Q. Simplificando a obtenção e a utilização de imagens digitais - scanners e câmeras digitais. R Dent Press Ortodon Ortop Facial, v. 9, n. 4, p. 133-56, jul./ago. 2004.

140. MAGILL, J.M. Changes in the anterior overbite relationship following orthodontic treatment in extraction cases. Am J Orthod, v. 46, n. 10, p. 775-88, Oct. 1960.

141. MALMGREN, O. et al. Root resorption after orthodontic treatment of traumatized teeth. Am J Orthod, v. 82, n. 6, p. 487-91, Dec. 1982.

142. MALTHA, J.C. et al. Incidence and severity of root resorption in orthodontically moved premolars in dogs. Orthod Craniofac Res, v. 7, n. 2, p. 115-21, May. 2004.

143. MARTINS, D.R. Mordida aberta anterior. Odontomaster, v. 1, n. 5, p. 105-33, 1994. 
144. MARTINS, D.R.; CANSANÇÄO, J.M.; FERNANDEZ SANCHEZ, J. Avaliaçäo radiográfica da reabsorçäo radicular, consecutiva ao tratamento ortodôntico (cinco anos após a remoçäo dos aparelhos). Ortodontia, v. 27, n. 3, p. 4-8, set./dez. 1994.

145. MASSLER, M.; MALONE, A.J. Root resorption in human permanent teeth. Am J Orthod, v. 40, n. 8, p. 619-33, Aug. 1954.

146. MASSLER, M.; PERREAULT, J. Root resorption in the permanent teeth of young adults. J Dent Child, v. 21, n., p. 158-64, 1954.

147. MAVRAGANI, M. et al. A radiographic comparison of apical root resorption after orthodontic treatment with a standard edgewise and a straightwire edgewise technique. Eur J Orthod, v. 22, n. 6, p. 665-74, Dec. 2000.

148. MC FADDEN, M.W.E.A. A study of the relationship between incisor intrusion and root shortening. Am J Orthod Dentofac Orthop, v. 96, n. 5, p. 390-6, Nov. 1989.

149. MCDOWELL, E.H.; BAKER, I.M. The skeletodental adaptations in deep bite correction. Am J Orthod Dentofacial Orthop, v. 100, n., p. 370-5, 1991.

150. MCFADDEN, W. et al. A study of the relationship between incisor intrusion and root shortening. Am J Orthod Dentofacial Orthop, v. 96, n. 5, p. 390-6, Nov. 1989.

151. MCNAB, S. et al. External apical root resorption following orthodontic treatment. Angle Orthod, v. 70, n. 3, p. 227-32, June. 2000.

152. MCNAMARA, J.A., JR. A method of cephalometric evaluation. Am J Orthod, v. 86, n. 6, p. 449-69, Dec. 1984.

153. MCNICOL, A.; STIRRUPS, D.R. Radiation dose during the dental radiographic techniques most frequently used during orthodontic treatment. Eur J Orthod, v. 7, n. 3, p. 163-71, Aug. 1985.

154. MELSEN, B.; AGERBAEK, N.; MARKENSTAM, G. Intrusion of incisors in adult patients with marginal bone loss. Am J Orthod Dentofacial Orthop, v. 96, n. 3, p. 232-41, Sep. 1989.

155. MENDONÇA, M.R. Reabsorção radicular apical: estudo comparativo entre dentes com vitalidade pulpar e tratados endodonticamente, quando submetidos à força ortodôntica de intrusão. Piracicaba, 1997. 109p. Tese (Doutorado) - Universidade Estadual de Campinas.

156. MIRABELLA, A.D.; ARTUN, J. Prevalence and severity of apical root resorption of maxillary anterior teeth in adult orthodontic patients. Eur J Orthod, v. 17, n. 2, p. 93-9, Apr. 1995.

157. MIRABELLA, A.D.; ARTUN, J. Risk factors for apical root resorption of maxillary anterior teeth in adult orthodontic patients. Am J Orthod Dentofacial Orthop, v. 108, n. 1, p. 48-55, Jul. 1995.

158. MITCHELL, D.L.; STEWART, W.L. Documented levelling of lower arch using metallic implants for reference. Am J Orthod, v. 63, n. 5, p. 526-32, May. 1973. 
159. MOYERS, R. Handbook of orthodontics. 4th ed ed: Chicago: Year Book Medical Publishers, 1988.

160. MOYERS, R.E. Ortodontia. $3^{a}$ ed. Rio de Janeiro: Guanabara Koogan, 1988.

161. MULLIGAN, T.F. Common sense mechanics. 3. J Clin Orthod, v. 13, n. 11, p. 762-6, Nov. 1979.

162. NANDA, R. The differential diagnosis and treatment of excessive overbite. Dent Clin North Am, v. 25, n. 1, p. 69-84, Jan. 1981.

163. NANDA, S.K. Patterns of vertical growth in the face. Am J Orthod Dentofacial Orthop, v. 93, n. 2, p. 103-16, Feb. 1988.

164. NANDA, S.K.; ROWE, T.K. Circumpuberal growth spurt related to vertical dysplasia. Angle Orthod, v. 59, n. 2, p. 113-22, Summer. 1989.

165. NEFF, C.W. Tailored occlusion with the anterior coefficient. Am J Orthod, v. 35, n., p. 309-13, 1949.

166. NEMETH, R.B.; ISAACSON, R.J. Vertical anterior relapse. Am J Orthod, v. 65, n. 6, p. 565-85, Jun. 1974.

167. NEWMAN, W.G. Possible etiologic factors in external root resorption. Am J Orthod, v. 67, n. 5, p. 522-39, May. 1975.

168. NGAN, D.C.S. et al. The genetic contribution to orthodontic root resorption: a retrospective twin study. Aust Orthod J, v. 20, n. 1, p. 1-9, May. 2004.

169. NOUER, D.F. et al. Reabsorção radicular pós-tratamento ortodôntico pela técnica de Tweed. J Bras Ortodontia Ortop Maxilar, v. 2, n. 11, p. 13-6, set./out. 1997.

170. ODEBRECHT, R.; CANTO, G.L.; BORTOLON, A.C. Estudo comparativo da reabsorção radicular apical em pacientes bruxônomos e pacientes sem sinais clínicos de desgaste dentário. R Dent Press Ortodon Ortop Facial, v. 9, n. 2, p. 44-9, mar./abr. 2004.

171. ODENRICK, L.; BRATTSTROM, V. The effect of nailbiting on root resorption during orthodontic treatment. Eur J Orthod, v. 5, n. 3, p. 185-8, Aug. 1983.

172. ODENRICK, L.; BRATTSTRÖM, V. Nailbiting: frequency and association with root resorption during orthodontic treatment. Br J Orthod, v. 12, n., p. 7881, 1985.

173. OTTO, R.L.; ANHOLM, J.M.; ENGEL, G.A. A comparative analysis of intrusion of incisor teeth achieved in adults and children according to facial type. Am J Orthod, v. 77, n. 4, p. 437-46, Apr. 1980.

174. OTTOLENGUI, R. The physiological and pathological resorption of tooth roots. Item of interest., v. 36, n., p. 332-362, 1914. 
175. OWMAN-MOLL, P.; KUROL, J.; LUNDGREN, D. Continuous versus interrupted continuous orthodontic force related to early tooth movement and root resorption. Angle Orthod, v. 65, n. 6, p. 395-401; discussion 401-2, 1995.

176. PARKER, C.D.; NANDA, R.S.; CURRIER, G.F. Skeletal and dental changes associated with the treatment of deep bite malocclusion. Am J Orthod Dentofacial Orthop, v. 4, n. 107, p. 382-93, Apr. 1995.

177. PARKER, R.J.; HARRIS, E.F. Directions of orthodontic tooth movements associated with external apical root resorption of the maxillary central incisor. Am J Orthod Dentofacial Orthop, v. 114, n. 6, p. 677-83, Dec. 1998.

178. PEREIRA, A. Influência da gravidez e dos anticoncepcionai na reabsorção radicular e na remodelação óssea, conseqüente à movimentação dentária induzida. Avaliação microscópica Bauru, 1995. 144p. Dissertação (Mestrado) - Faculdade de Odontologia de BauruUniversidade de São Paulo.

179. PHILLIPS, J.R. Apical root resorption under orthodontic therapy. Angle Orthodont, v. 25, n. 1, p. 1-22, Jan. 1955.

180. PINZAN, A. Estudo comparativo da sobremordida e da profundidade das curvas de Spee e ocluso-incisal, em jovens leucodermas brasileiras, com "oclusão normal" e com Classe II, div. I, tratadas ortodonticamente. Bauru, 1982. 123p. Tese (Doutorado) - Universidade de São Paulo.

181. POLLARD, L.E.; MAMANDRAS, A.H. Male postpuberal facial growth in Class II malocclusions. Am J Orthod Dentofacial Orthop, v. 108, n. 1, p. 62-8, Jul. 1995.

182. POPOVICH, F. Cephalometric evaluation of vertical overbite in young adults. J Canad Dent Ass, v. v.21, n. n.4, p. p.209-22, Sept. 1955.

183. PRAKASH, P.; MARGOLIS, H.I. Dento-craniofacial relations in varying degrees of overbite. Am J Orthod, v. 38, n. 9, p. 657-73, Sept. 1952.

184. PROFFIT, W.R.; FIELDS JR, H.W. Ortodontia contemporânea. 3. ed. ed. Rio de Janeiro: Guanabara Koogan, 2002.

185. PUCHE, L.R. Reabsorcion radicular y ortodoncia. Acta. Odontol. Venez., v. 31, n. 1, p. 44-45, Apr. 1993.

186. REITAN, K. Initial tissue behavior during apical root resorption. Angle Orthod, v. 44, n. 1, p. 68-82, Jan. 1974.

187. REITAN, K.; RYGH, P. Princípios e reações biomecânicas. In: GABER T.M.; VANARSDALL JR. R.L. Princípios e técnicas atuais. Rio de Janeiro: Guanabara Koogan; 1996. p. 88-165.

188. REMINGTON, D.N. et al. Long-term evaluation of root resorption occurring during orthodontic treatment. Am J Orthod Dentofacial Orthop, v. 96, n. 1, p. 43-6, Jul. 1989.

189. REUKERS, E. et al. Assessment of apical root resorption using digital reconstruction. Dentomaxillofac Radiol, v. 27, n. 1, p. 25-9, Jan. 1998. 
190. RICHARDSON, A. Skeletal factors in anterior open-bite and deep overbite. Am J Orthod, v. 56, n. 2, p. 114-27, Aug. 1969.

191. RICHMOND, S. et al. The development of the PAR index (Peer assessment rating): reliability and validity. Eur J Orthod, v. 14, n. 2, p. 125-39, Apr. 1992.

192. RICKETTS, R.M. Features of the bioprogressive therapy. Denver, 1979.

193. RIEDEL, R.A. A cephalometric roentgenographic study of the relation of the maxilla and associated parts to the cranial base in normal and malocclusion of the teeth, 1948Master - Northwestern University.

194. ROSENBERG, E.H.; GURALNICK, W.C. Hyperparathyreoidism: a review of 220 proven cases, with special emphasis on findings in the jaws. Oral Surg, v. 15, n. 2, p. 84, 1962.

195. RUDOLPH, C. An evaluation of root resorption occurring during orthodontic treatment. J Dent Res, v. 19, n., p. 295, 1940.

196. RUDOLPH, D.J.; WILLES, P.M.G.; SAMESHIMA, G.T. A finite element model of apical force distribution from orthodontic tooth movement. Angle Orthod, v. 71, n. 2, p. 127-31, Apr. 2001.

197. RYGH, P. Orthodontic root resorption studied by electron microscopy. Angle Orthod, v. 47, n. 1, p. 1-16, Jan. 1977.

198. SAKIMA, M.T. Avaliação cefalométrica comparativa de dois métodos de correção da sobremordida. Estudo com implantes metálicos. Araraquara, 1997. 241p. Tese (Doutorado) - Universidade Estadual Paulista.

199. SAKIMA, M.T. et al. Avaliação cefalométrica comparativa da dois métodos de correção da sobremordida. Estudo com implantes metálicos - Parte I. R Dent Press Ortodon Ortop Facial, v. 5, n. 4, p. 6-17, jul./ago. 2000.

200. SAKIMA, M.T. et al. Avaliação cefalométrica comparativa da dois métodos de correção da sobremordida. Estudo com implantes metálicos - Parte II. R Dent Press Ortodon Ortop Facial, v. 5, n. 5, p. 47-57, set./out. 2000.

201. SALFATIS, M. A comparative cephalometric study on effects of directional force versus straight-wire intrusive mechanics in Class II malocclusions Saint Louis, 1995. 102p. Master's Thesis - Saint Louis University.

202. SALZMANN, J.A. Practice of orthodontics. 24. ed. Philadelphia: J. B. Lippincott Company, 1966.

203. SAMESHIMA, G.T.; ASGARIFAR, K.O. Assessment of root resorption and root shape: periapical vs panoramic films. Angle Orthod, v. 71, n. 3, p. 185-9, Jun. 2001.

204. SAMESHIMA, G.T.; SINCLAIR, P.M. Characteristics of patients with severe root resorption. Orthod Craniofac Res, v. 7, n. 2, p. 108-14, May. 2004. 
205. SAMESHIMA, G.T.; SINCLAIR, P.M. Predicting and preventing root resorption: Part I. Diagnostic factors. Am J Orthod Dentofacial Orthop, v. 119, n. 5, p. 505-10, May. 2001.

206. SAMESHIMA, G.T.; SINCLAIR, P.M. Predicting and preventing root resorption: Part II. Treatment factors. Am J Orthod Dentofacial Orthop, v. 119, n. 5, p. 511-5, May. 2001.

207. SAMUELSON, G.; GARNER, L.D.; POTER, R. Tooth movements associated with deep overbite correction in Classe II, Division 1 malocclusions. Int J Orthod, v. 27, n. 3/4, p. 3-8, 1989.

208. SANDLER, J. Digital records in orthodontics. Pa Dent J (Harrisb), v. 68, n. 6, p. 29-33, Nov-Dec. 2001.

209. SANDLER, P. Reproducibility of cephalometric measurements. BritJ Orthodont, v. 15, n. 2, p. 105-10, May. 1988.

210. SASSOUNI, V. A classification of skeletal facial types. Am J Orthod, v. 55, n. 2, p. 109-23, Feb. 1969.

211. SCHUDY, F.F. The control of vertical overbite in clinical orthodontics. Angle Orthod, v. 38, n. 1, p. 19-39, Jan. 1968.

212. SEGAL, G.R.; SCHIFFMAN, P.H.; TUNCAY, O.C. Meta analysis of the treatment-related factors of external apical root resorption. Orthod Craniofac Res, v. 7, n. 2, p. 71-8, May. 2004.

213. SHANNON, K.R.; NANDA, R.S. Changes in the curve of Spee with treatment and at 2 years posttreatment. Am J Orthod Dentofacial Orthop, v. 125, n. 5, p. 589-96, May. 2004.

214. SHAW, A.M.; SAMESHIMA, G.T.; VU, H.V. Mechanical stress generated by orthodontic forces on apical root cementum: a finite element model. Orthod Craniofac Res, v. 7, n. 2, p. 98-107, May. 2004.

215. SHROFF, B. et al. Simultaneous intrusion and retraction using a threepiece base arch. Angle Orthod, v. 67, n. 6, p. 455-62, 1997.

216. SILVA FILHO, O.G. et al. Estimativa da reabsorção radicular em 50 casos ortodônticos bem finalizados. Ortodontia, v. 26, n. 1, p. 24-35, jan./abr. 1993.

217. SMALE, I. et al. Apical root resorption 6 months after initiation of fixed orthodontic appliance therapy. Am J Orthod Dentofacial Orthop, v. 128, n. 1, p. 57-67, Jul. 2005.

218. SMITH, R.J.; BURSTONE, C.J. Mechanics of tooth movement. Am J Orthod, v. 85, n. 4, p. 294-307, Apr. 1984.

219. SPURRIER, S.W. et al. A comparison of apical root resorption during orthodontic treatment in endodontically treated and vital teeth. Am J Orthod Dentofacial Orthop, v. 97, n. 2, p. 130-4, Feb. 1990.

220. STAGGERS, J.A. Vertical changes following first premolar extractions. Am J Orthod Dentofacial Orthop, v. 105, n. 1, p. 19-24, Jan. 1994. 
221. STEADMAN, S.R. Overbite and overjet predetermining. Angle Orthod, v. 19, n. 2, p. 101-5, Apr. 1949.

222. STEINER, C.C. Cephalometrics for you and me. Am J Orthod, v. 84, n. 4, p. 337-43, Oct. 1953.

223. STRANG, R.H.W. Estudio de los casos. In: ARGENTINA E.B. Tratado de Ortodoncia. Buenos Aires.; 1957. p. 288-300.

224. STUTEVILLE, B.S. Injuries caused by orthodontic forces and the ultimate results of these injuries. Am J Orthod Oral Surg, v. 24, n. 2, p. 1938.

225. SWARTZ, M.L. Managing digital images. Am J Orthod Dentofacial Orthop, v. 118, n. 3, p. 354-8, Sep. 2000.

226. TAHIR, E.; SADOWSKY, C.; SCHNEIDER, B.J. An assessment of treatment outcome in American Board of Orthodontics cases. Am J Orthod Dentofacial Orthop, v. 111, n. 3, p. 335-42, Mar. 1997.

227. TAITHONGCHAI, R.; SOOKKORN, K.; KILLIANY, D.M. Facial and dentoalveolar structure and the prediction of apical root shortening. Am J Orthod Dentofacial Orthop, v. 110, n. 3, p. 296-302, Sep. 1996.

228. TANER, T.; CIGER, S.; SENCIFT, Y. Evaluation of apical root resorption following extraction therapy in subjects with Class I and Class II malocclusions. Eur J Orthod, v. 21, n., p. 491-6, 1999.

229. THONGUDOMPORN, U.; FREER, T.J. Anomalous dental morphology and root resorption during orthodontic treatment: a pilot study. Aust Orthod $\mathbf{J}$, v. 15, n. 3, p. 162-7, Oct. 1998.

230. TIBOLA, D. et al. Fundamentos atuais na etiopatogenia da reabsorção dentária e fatores relacionados à movimentação dentária induzida. Rev Ass Paul Espec Ortodon Ortop Fac, v. 3, n. 2, p. 122-35, abr-mai-jun. 2005.

231. TRONSTAD, L. Root resorption: a multidisciplinary problem in dentistry. In: DAVIDOVICH Z. Biological mechanisms of tooth eruption and root resorption. Ohio: Columbus; 1988. p. 293-306.

232. TWEED, C.H. The application of the principles of the Edgewise arch in the

treatment of Class II, division 1 malocclusion: part 2. Angle Orthodont, v. 11, n. 1, p. 12-67, Jan. 1941.

233. TWEED, C.H. The Frankfort mandibular incisor angle (FMIA) in orthodontic diagnosis, treatment planning and prognosis. Angle Orthodont, $v$. 24, n. 3, p. 121-69, jul. 1954.

234. TWEED, C.H. Indications for the extractions of teeth in orthodontic procedures. Amer J Orthodont Oral Surg, v. 30, n., p. 405-28, Jul/Dec. 1944.

235. TYROVOLA, J.B.; SPYROPOULOS, M.N. Effects of drugs and systemic factors on orthodontic treatment. Quintessence Int, v. 32, n. 5, p. 365-71, May. 2001. 
236. VADEN, J.L. Sequential directional forces treatment: two Class II case reports. Am J Orthod Dentofacial Orthop, v. 99, n. 6, p. 491-504, Jun. 1991.

237. VADEN, J.L.; HARRIS, E.F.; BEHRENTS, R.G. Adult versus adolescent Class II correction: a comparison. Am J Orthod Dentofacial Orthop, v. 107, n. 6, p. 651-61, Jun. 1995.

238. VALLADARES NETO, J. Análise do complexo dentino-pulpar e da superfície

radicular externa após a expansão rápida da maxila em adolescentes, 2000. 199 fp. Dissertação (Mestrado) - Universidade Federal de Goias.

239. VAN DER LINDEN, F.P.G. Desenvolvimento da Dentição. Rio de Janeiro: Quintessence, 1986.

240. VAN STEENBERGEN, E. et al. The role of a high pull headgear in counteracting side effects from intrusion of the maxillary anterior segment. Angle Orthod, v. 74, n. 4, p. 480-6, Aug. 2004.

241. VANDEN BULCKE, M.M. et al. The center of resistance of anterior teeth during intrusion using the laser reflection technique and holographic interferometry. Am J Orthod Dentofacial Orthop, v. 90, n. 3, p. 211-20, Sep. 1986.

242. VAUGHAN, J.L. Orthodontic correction of an adult Angle Class II Division 2 deep bite. Am J Orthod Dentofacial Orthop, v. 116, n. 1, p. 75-81, Jul. 1999.

243. VONDERAHE, G. Postretention status of maxillary incisors with root-end resorption. Angle Orthod, v. 43, n. 3, p. 247-55, Jul. 1973.

244. WEILAND, F.J.; BANTLEON, H.P.; DROSCHI, H. Evaluation of continuous arch and segmented arch leveling techniques in adult patients - a clinical study. Am J Orthod Dentofacial Orthop, v. 110, n. 6, p. 647-652, Dec. 1996.

245. WICKWIRE, N.A.; AL., E. The effects of tooth movement upon endodontically treated teeth. Angle Orthod, v. 44, n. 3, p. 235-42, July. 1974.

246. WILSON, A.N. et al. The finite element analysis of stress in the periodontal ligament when subject to vertical orthodontic forces. $\mathbf{B r} \mathbf{J}$ Orthod, $\mathrm{v}$. 21, n. 2, p. 161-7, May. 1994.

247. ZACHRISSON, B.U. Cause and prevention of injuries to teeth and supporting structures during orthodontic treatment. Am J Orthod, v. 69, n. 3, p. 285-300, Mar. 1976.

248. ZINGESER, M.R. Vertical response to Class II, division 1 therapy. Angle Orthod, v. 34, n. 1, p. 58-64, Jan. 1964. 
Abstract 


\section{ABSTRACT \\ INFLUENCE OF INTRUSION COMBINED TO ANTERIOR RETRACTION IN APICAL RESORPTION DEGREE CONSEQUENT TO INDUCED DENTAL MOVEMENT}

The objective of this study was to evaluate the influence of intrusion force in the occurrence of root resorption in the maxillary incisors, in 56 patients treated with premolars extraction in the Edgewise technique. The sample was retrospectively selected from the files of the Orthodontic Department at Bauru Dental School, University of São Paulo. Group 1 comprised 28 patients with accentuated overbite and overjet $(4.78 \pm 1.18 \mathrm{~mm}$ and $6.48 \pm 2.52 \mathrm{~mm}$, respectively). Group 2 also was composed by 28 patients and presented accentuated overjet $(5.67 \pm 2.73 \mathrm{~mm})$, but with normal overbite $(1.12 \pm 0.97$ $\mathrm{mm}$ ). The initial mean ages were $13.41 \pm 2.38$ and $13.27 \pm 1.85$ years, respectively. Periapical radiographs from the pre and post treatment period were used to evaluate the amount of root resorption, according to the method of Malmgren. The groups were compared with the nonparametric Mann-Whitney test. The correlation between the degree of root resorption with the initial overjet, the amount of overjet correction, the amount of vertical and horizontal movement of the root apex, obtained in the cephalograms, and the treatment time were evaluated with the Spearman correlation coefficient. A comparison of the degree of root resorption between the central and lateral incisors, to define which was the most affected, was performed with the Wilcoxon test. The results showed a greater amount of root resorption in the group of patients treated with both retraction and intrusion mechanics. The amount of root resorption was statistically significant correlated with the initial overbite and with the amount of its correction. The maxillary central and lateral incisors were similarly affected in the amount of root resorption.

Key words: Orthodontics. Malocclusion. Root Resorption. Tooth Movement. Tooth Intrusion. 
Apêndice 
As tabelas A1 e A2 apresentam as características individuais de cada paciente dos grupos 1 e 2

TABELA A1 - (Grupo 1) Pacientes com trespasse vertical e horizontal acentuados

\begin{tabular}{|c|c|c|c|c|c|c|c|c|}
\hline Paciente & Núm & Gr & Gen & Classe & Exodontias & $\begin{array}{l}\text { Id. Inicial } \\
\text { (anos) }\end{array}$ & $\begin{array}{l}\text { Id. Final } \\
\text { (anos) }\end{array}$ & $\begin{array}{l}\text { Tem.Trat. } \\
\text { (meses) }\end{array}$ \\
\hline 1. A. F. C. & $112 \mathrm{M} 10-\mathrm{PG}$ & 1 & $\mathrm{~F}$ & $\mathrm{Cl} I \mathrm{I}, 1$ & $14,24,34,44$ & 12 & 14,16 & 25,92 \\
\hline 2. A. M. & $72-E$ & 1 & $\mathrm{M}$ & $\mathrm{Cl} \mathrm{II,1}$ & 14,24 & 14,33 & 16,14 & 21,73 \\
\hline 3. A. P. L. & $143-P G$ & 1 & $\mathrm{~F}$ & $\mathrm{Cl} \mathrm{II,1}$ & 14,24 & 12,83 & 15,58 & 33,07 \\
\hline 4. B. T. N. & 105D11 - PG & 1 & $\mathrm{~F}$ & $\mathrm{Cl} \| \mathrm{I}, 1$ & $14,24,34,44$ & 12,33 & 14,51 & 26,23 \\
\hline 5. B. B. A. & $328-E$ & 1 & $\mathrm{~F}$ & $\mathrm{Cl} \mathrm{II,1}$ & 14,24 & 18,5 & 21,27 & 33,23 \\
\hline 6. B. L. L. & $346-E$ & 1 & $\mathrm{M}$ & $\mathrm{Cl} \mathrm{II,2}$ & 14,24 & 11,5 & 15,25 & 45 \\
\hline 7. C.S. Z. & 498 - PG & 1 & $\mathrm{~F}$ & $\mathrm{Cl} \mathrm{II,2}$ & 14,24 & 11,33 & 12,93 & 19,17 \\
\hline 8. C.P. V.B. & 147A20 - PG & 1 & $\mathrm{~F}$ & $\mathrm{Cl} I \mathrm{I}, 1$ & $14,24,35,45$ & 14,58 & 17,66 & 36,96 \\
\hline 9. D. B. P. & $702-A C$ & 1 & $M$ & $\mathrm{Cl} I \mathrm{I}, 1$ & 14,24 & 15,17 & 18,81 & 43,73 \\
\hline 10. E. M. M. & $659-E$ & 1 & $\mathrm{M}$ & $\mathrm{Cl} I \mathrm{I}, 1$ & $14,24,34,44$ & 13,17 & 15,54 & 28,5 \\
\hline 11. E. S. P. & $671-E$ & 1 & M & $\mathrm{Cl} I \mathrm{I}, 2$ & 14,24 & 15,08 & 16,92 & 22,1 \\
\hline 12. H. E. T. C. & $1029-E$ & 1 & $\mathrm{M}$ & $\mathrm{Cl} \mathrm{II,1}$ & $14,24,34,44$ & 11,33 & 14,57 & 38,93 \\
\hline 13. H. A. J. S. & $1028-E$ & 1 & $M$ & $\mathrm{Cl} I \mathrm{I}, 1$ & 14,24 & 12,67 & 14,44 & 21,2 \\
\hline 14. I. A. M. & $1066-E$ & 1 & $\mathrm{M}$ & $\mathrm{Cl} \mathrm{II,2}$ & 14,24 & 14,67 & 15,99 & 15,83 \\
\hline 15. J. P. L. & $1205-E$ & 1 & $M$ & $\mathrm{Cl} I \mathrm{I}, 1$ & $14,24,34,44$ & 13,25 & 14,83 & 19 \\
\hline 16. J. C. P. & 107D15 - PG & 1 & $\mathrm{M}$ & $\mathrm{Cl} \mathrm{II,1}$ & $14,24,34,44$ & 12,41 & 16,58 & 50,04 \\
\hline 17. L. F. R. & $1354-E$ & 1 & $\mathrm{~F}$ & $\mathrm{Cl} \| \mathrm{I}, 1$ & 14,24 & 11,92 & 13,52 & 19,17 \\
\hline 18. L. E. B. & $1394-E$ & 1 & $\mathrm{M}$ & $\mathrm{Cl} \mathrm{II,1}$ & 14,24 & 12,33 & 14,02 & 20,27 \\
\hline 19. M. C. & $1448-E$ & 1 & $\mathrm{M}$ & $\mathrm{Cl} \mathrm{II,1}$ & $14,24,34,44$ & 11,25 & 12,55 & 15,63 \\
\hline 20. M. E. A. P. & 126 - PG & 1 & $\mathrm{~F}$ & $\mathrm{Cl} \mathrm{II,1}$ & 14,24 & 21,5 & 23,32 & 21,87 \\
\hline 21. M. S. & 25P3 - PG & 1 & $\mathrm{~F}$ & $\mathrm{Cl} I \mathrm{I}, 1$ & $14,24,34,44$ & 16,33 & 18,41 & 24,96 \\
\hline 22. P. C. P. & $1731-E$ & 1 & $\mathrm{~F}$ & $\mathrm{Cl} \mathrm{II,2}$ & 14,24 & 13,33 & 16,11 & 33,4 \\
\hline 23. P. R. L. & $103 M 14-P G$ & 1 & M & $\mathrm{Cl} I \mathrm{I}, 1$ & $14,24,34,44$ & 13,41 & 16,41 & 36 \\
\hline 24. P. G. O. & $1775-E$ & 1 & $\mathrm{~F}$ & $\mathrm{Cl} \mathrm{II,1}$ & 14,24 & 12,92 & 14,52 & 19,27 \\
\hline 25. R. R. M. & $224-A c$ & 1 & $\mathrm{M}$ & $\mathrm{Cl} \mathrm{II,1}$ & 14,24 & 9,42 & 11,41 & 23,87 \\
\hline 26. R. P. O. & $1884-E$ & 1 & $\mathrm{M}$ & $\mathrm{Cl} \mathrm{II,2}$ & 14,24 & 12 & 14,88 & 34,57 \\
\hline 27. T. D. S. & $31-A c$ & 1 & $\mathrm{~F}$ & $\mathrm{Cl} \mathrm{II,2}$ & 14,24 & 13,17 & 15,92 & 33 \\
\hline 28. V. C. R. & $2172-E$ & 1 & $\mathrm{M}$ & $\mathrm{Cl} I \mathrm{I}, 1$ & $14,24,34,44$ & 12,83 & 14,51 & 20,2 \\
\hline
\end{tabular}


TABELA A2 - (Grupo 2) Pacientes com trespasse vertical normal e horizontal acentuado

\begin{tabular}{|c|c|c|c|c|c|c|c|c|}
\hline Paciente & Núm & Grp & Gen & Classe & Exodontias & $\begin{array}{l}\text { Id.Inicial } \\
\text { (anos) }\end{array}$ & $\begin{array}{l}\text { Id. Final } \\
\text { (anos) }\end{array}$ & $\begin{array}{l}\text { Tem.Trat. } \\
\text { (meses) }\end{array}$ \\
\hline 1. A. C. & 281F34 & 2 & $\mathrm{~F}$ & $\mathrm{Cl} \mathrm{II,1}$ & $14,24,34,44$ & 11,67 & 14 & 27,96 \\
\hline 2. A. L. P. L. & 213D23 & 2 & $F$ & $\mathrm{Cl} \mathrm{II,1}$ & $14,24,34,44$ & 12,25 & 15,41 & 37,92 \\
\hline 3. C. H. P. & $134 \mathrm{~F} 20$ & 2 & M & $\mathrm{Cll}$ & $14,24,34,44$ & 12,33 & 14,83 & 30 \\
\hline 4. C. C. O. & $443 \mathrm{~A}$ & 2 & M & $\mathrm{Cl} \mathrm{II,1}$ & $14,34,44,44$ & 14,17 & 16,75 & 30,96 \\
\hline 5. C. P. M & 474G56 & 2 & $\mathrm{~F}$ & $\mathrm{Cl} \mathrm{II,1}$ & $14,24,35,45$ & 12,5 & 15,91 & 40,92 \\
\hline 6. E. C. & $211 \mathrm{M} 23$ & 2 & $\mathrm{~F}$ & $\mathrm{ClI}$ & $14,24,34,44$ & 14,58 & 17,08 & 30 \\
\hline 7. F. L. S. & 314A39 & 2 & $M$ & $\mathrm{ClI}$ & $14,24,34,44$ & 11,58 & 13,08 & 18 \\
\hline 8. F. R. P. L. & $823 \mathrm{~A}$ & 2 & M & $\mathrm{Cl} \mathrm{II,1}$ & $14,24,35,45$ & 14,67 & 16,83 & 25,92 \\
\hline 9. F. N. S. & $844 \mathrm{~A}$ & 2 & M & $\mathrm{Cll}$ & $14,24,34,44$ & 11,25 & 14,75 & 42 \\
\hline 10. F. P. N. & 70L8 & 2 & M & $\mathrm{Cl} \mathrm{II,1}$ & $14,24,34,44$ & 13,16 & 14,66 & 18,96 \\
\hline 11. H. C. G. & 180D22 & 2 & M & $\mathrm{Cl} \mathrm{II,1}$ & $14,24,34,44$ & 12,83 & 14,5 & 31,92 \\
\hline 12. J. L. T. C. & 33P4 & 2 & $\mathrm{~F}$ & $\mathrm{Cl} \mathrm{II,1}$ & $14,24,35,45$ & 16,33 & 19,33 & 36 \\
\hline 13. J. E. S. C. & $121 C 15$ & 2 & $M$ & $\mathrm{ClI}$ & $14,24,34,44$ & 12,41 & 16,25 & 33,96 \\
\hline 14. J. F. S. L. & 177D25 & 2 & M & $\mathrm{Cll}$ & $14,24,34,44$ & 12,16 & 14,41 & 27 \\
\hline 15. J. R. D. & $209 \mathrm{M} 23$ & 2 & M & $\mathrm{ClI}$ & $14,24,34,44$ & 12,58 & 14,41 & 21,96 \\
\hline 16. K. T. & 297M32 & 2 & M & $\mathrm{ClI}$ & $14,24,34,44$ & 12,83 & 14,75 & 34,92 \\
\hline 17. L. F. R. & $1354 \mathrm{~A}$ & 2 & $\mathrm{~F}$ & $\mathrm{Cl} \mathrm{II,1}$ & 14,24 & 11,92 & 14 & 24,96 \\
\hline 18. L. G. C. & 127usp & 2 & $F$ & $\mathrm{Cl} \mathrm{II,1}$ & $14,24,35,45$ & 11,5 & 14,33 & 33,96 \\
\hline 19. M. M. B. & Ac227 & 2 & M & $\mathrm{Cl} I \mathrm{I}, 1$ & $14,24,35,45$ & 11,16 & 13,66 & 30 \\
\hline 20. M. P. P. & $217 F 22$ & 2 & M & $\mathrm{Cl} \mathrm{II,1}$ & 14,24 & 19,33 & 20,83 & 18 \\
\hline 21. M. R. & 133M20 & 2 & M & $\mathrm{Cll}$ & $14,24,34,44$ & 14,25 & 16,66 & 28,92 \\
\hline 22. M. A. P. P. & $56 \mathrm{~L} 6$ & 2 & $\mathrm{~F}$ & $\mathrm{ClI}$ & $14,24,34,44$ & 13,41 & 15 & 18,96 \\
\hline 23. M. A. O. S. & Ac48 & 2 & $\mathrm{~F}$ & $\mathrm{Cll}$ & $14,24,34,44$ & 17,17 & 20,17 & 36 \\
\hline 24. M. G. B. & 173D21 & 2 & $\mathrm{~F}$ & $\mathrm{ClI}$ & $14,24,34,44$ & 13 & 16,33 & 39,96 \\
\hline 25. R. N. C. & 111A15 & 2 & $\mathrm{~F}$ & $\mathrm{ClI}$ & $14,24,34,44$ & 12,5 & 15,41 & 34,92 \\
\hline 26. U.C.S. & 41L8 & 2 & M & $\mathrm{ClI}$ & $14,24,34,44$ & 12,75 & 14,33 & 18,96 \\
\hline 27. V. G. & 184D24 & 2 & $\mathrm{~F}$ & $\mathrm{Cl} \mathrm{II,1}$ & $14,24,35,45$ & 14,4 & 16,49 & 25,08 \\
\hline 28. W. A. V. B. & $2218 \mathrm{~A}$ & 2 & $M$ & $\mathrm{Cl} I \mathrm{I}, 1$ & 14,24 & 13 & 15,16 & 25,92 \\
\hline
\end{tabular}


As tabelas A3 e A4 apresentam os escores do grau de reabsorção radicular de cada dente e sua média para cada paciente.

Tabela A3 - Escores do grau de reabsorção obtido ao final do tratamento, dos incisivos superiores $(12,11,21,22)$ e a média para cada paciente do grupo 1

\begin{tabular}{l|c|c|c|c|c}
\hline \multicolumn{1}{l|}{ Nomes } & $\mathbf{1 2}$ & $\mathbf{1 1}$ & $\mathbf{2 1}$ & $\mathbf{2 2}$ & Média \\
\hline 1. A. F. C. & 2 & 2 & 2 & 1 & 1,75 \\
\hline 2. A. M. & 3 & 3 & 3 & 3 & 3 \\
\hline 3. A. P. L. & 3 & 3 & 3 & 3 & 3 \\
\hline 4. B. T. N. & 2 & 2 & 2 & 3 & 2,25 \\
\hline 5. B. B. A. & 1 & 1 & 1 & 2 & 1,25 \\
\hline 6. B. L. L. & 4 & 3 & 4 & 4 & 3,75 \\
\hline 7. C. S. Z. & 3 & 3 & 4 & 3 & 3,25 \\
\hline 8. C. P. V. B. & 2 & 3 & 3 & 3 & 2,75 \\
\hline 9. D. B. P. & 2 & 3 & 2 & 2 & 2,25 \\
\hline 10. E. M, M. & 3 & 3 & 3 & 3 & 3 \\
\hline 11. E. S. P. & 1 & 1 & 1 & 1 & 1 \\
\hline 12. H. E. T. C. & 3 & 3 & 3 & 3 & 3 \\
\hline 13. H. A. J. S. & 1 & 1 & 2 & 1 & 1,25 \\
\hline 14. I. A. M. & 3 & 2 & 3 & 2 & 2,5 \\
\hline 15. J. P. L. & 2 & 3 & 2 & 3 & 2,5 \\
\hline 16. J. C. P. & 3 & 4 & 4 & 3 & 3,5 \\
\hline 17. L. F. R. & 2 & 2 & 2 & 2 & 2 \\
\hline 18. L. E. B. & 1 & 1 & 1 & 2 & 1,25 \\
\hline 19. M. C. & 1 & 3 & 1 & 1 & 1,5 \\
\hline 20. M. E. A. P. & 3 & 2 & 2 & 3 & 2,5 \\
\hline 21. M. S. & 2 & 3 & 3 & 4 & 3 \\
\hline 22. P. C. P. & 2 & 2 & 2 & 3 & 2,25 \\
\hline 23. P. R. L. & 3 & 3 & 3 & 2 & 2,75 \\
\hline 24. P. G. O. & 2 & 1 & 2 & 3 & 2 \\
\hline 25. R. R. M. & 3 & 2 & 3 & 3 & 2,75 \\
\hline 26. R. P. O. & 3 & 2 & 2 & 3 & 2,5 \\
\hline 27. T. D. S. & 2 & 2 & 2 & 2 & 2 \\
\hline 28. V. C. R. & 2 & 3 & 2 & 1 & 2 \\
\hline & & & & & \\
\hline
\end{tabular}


Tabela A4 - Escores do grau de reabsorção obtido ao final do tratamento, dos incisivos superiores $(12,11,21,22)$ e a média para cada paciente do grupo 2

\begin{tabular}{|c|c|c|c|c|c|}
\hline Nomes & 12 & 11 & 21 & 22 & Média \\
\hline 1. A.C. & 2 & 1 & 1 & 2 & 1,5 \\
\hline 2. A. L. $P$ L. & 2 & 2 & 2 & 2 & 2 \\
\hline 3. C. H. P. & 2 & 2 & 2 & 2 & 2 \\
\hline 4. c. c. 0 . & 2 & 2 & 2 & 2 & 1,5 \\
\hline 5. C. P. M & 2 & 1 & 1 & 2 & 1,5 \\
\hline 6. E. C. & 3 & 2 & 2 & 2 & 2,25 \\
\hline 7. F.L.S. & 1 & 1 & 1 & 1 & 1 \\
\hline 8. F. R. P. L. & 2 & 2 & 2 & 2 & 2 \\
\hline 9. $\quad$ F. N. S. & 1 & 2 & 2 & 1 & 1,5 \\
\hline 10. F. P. N. & 2 & 2 & 2 & 2 & 2 \\
\hline 11. H. C. G. & 2 & 2 & 2 & 2 & 2 \\
\hline 12. J. L T C. & 2 & 3 & 3 & 2 & 2,5 \\
\hline 13. J. E. S. C. & 2 & 1 & 1 & 1 & 1,25 \\
\hline 14. J. F. S. L. & 2 & 2 & 2 & 2 & 2 \\
\hline 15. J. R. D. & 3 & 3 & 3 & 3 & 3 \\
\hline 16. K. T. & 2 & 1 & 1 & 2 & 1,5 \\
\hline 17. L. F. R. & 1 & 1 & 1 & 1 & 1 \\
\hline 18. L. G. C. & 1 & 1 & 1 & 1 & 1 \\
\hline 19. M. M. B. & 1 & 1 & 1 & 1 & 1 \\
\hline 20. M.P.P. & 2 & 2 & 2 & 2 & 2 \\
\hline 21. M. R. & 2 & 2 & 1 & 2 & 1,75 \\
\hline 22. M. A. P. P. & 1 & 1 & 1 & 1 & 1 \\
\hline 23. M.AOS. & 1 & 1 & 1 & 1 & 1 \\
\hline 24. M. G. B. & 2 & 2 & 2 & 2 & 2 \\
\hline 25. R. N. C. & 2 & 1 & 2 & 1 & 1,5 \\
\hline 26. U.C.S. & 2 & 1 & 1 & 2 & 1,5 \\
\hline 27. V. G. & 3 & 3 & 3 & 3 & 3 \\
\hline 28. W. A. V. B. & 1 & 2 & 1 & 1 & 1,25 \\
\hline
\end{tabular}


As tabelas A5 e A6 apresentam os escores obtidos na segunda avaliação da reabsorção ao final do tratamento de 15 pacientes de cada grupo para averiguação do erro do método e concordância inter-examinadores, respectivamente

Tabela A5 - Escores de reabsorção obtidos na segunda avaliação do grupo 1 para averiguação do erro do método

\begin{tabular}{l|c|c|c|c}
\hline \multicolumn{1}{c|}{ Nomes } & $\mathbf{1 2}$ & $\mathbf{1 1}$ & $\mathbf{2 1}$ & $\mathbf{2 2}$ \\
\hline 5. B. B. A. & 1 & 1 & 1 & 2 \\
\hline 6. B. L. L. & 4 & 3 & 4 & 4 \\
\hline 9. D. B. P. & 2 & 3 & 3 & 2 \\
\hline 10. E. M. M. & 3 & 3 & 3 & 2 \\
\hline 11. E. S. P. & 1 & 1 & 1 & 1 \\
\hline 12. H. E. T. C. & 3 & 2 & 2 & 2 \\
\hline 13. H. A. J. S. & 1 & 1 & 2 & 1 \\
\hline 15. J. P. L. & 2 & 3 & 2 & 3 \\
\hline 17. L. F. R. & 2 & 1 & 1 & 2 \\
\hline 18. L. E. B. & 1 & 1 & 1 & 2 \\
\hline 19. M. C. & 1 & 2 & 2 & 1 \\
\hline 22. P. C. P. & 2 & 2 & 2 & 3 \\
\hline 25. R. R. M. & 3 & 2 & 3 & 3 \\
\hline 26. R. P. O. & 3 & 2 & 2 & 3 \\
\hline 28. V. C. R. & 2 & 3 & 2 & 1 \\
\hline
\end{tabular}

Tabela A6 - Escores de reabsorção obtidos pelo $2^{\circ}$ examinador no grupo 2 para averiguação da concordância inter-examinadores

\begin{tabular}{l|c|c|c|c}
\hline \multicolumn{1}{c|}{ Nomes } & $\mathbf{1 2}$ & $\mathbf{1 1}$ & $\mathbf{2 1}$ & $\mathbf{2 2}$ \\
\hline 3. C. H. P. & 2 & 2 & 2 & 2 \\
\hline 10. F. P. N. & 2 & 3 & 3 & 2 \\
\hline 11. H. C. G. & 3 & 3 & 2 & 2 \\
\hline 12. J. L. T. C. & 2 & 3 & 3 & 3 \\
\hline 13. J. E. S. C. & 2 & 2 & 2 & 2 \\
\hline 14. J. F. S. L. & 2 & 2 & 2 & 2 \\
\hline 18. L. G. C. & 1 & 1 & 1 & 1 \\
\hline 21. M. R. & 2 & 2 & 1 & 2 \\
\hline 22. M. A. P. P. & 1 & 2 & 2 & 1 \\
\hline 23. M. A. O. S. & 2 & 2 & 2 & 3 \\
\hline 24. M. G. B. & 2 & 2 & 2 & 2 \\
\hline 25. R. N. C. & 2 & 1 & 2 & 1 \\
\hline 26. U. C. S. & 2 & 1 & 1 & 3 \\
\hline 27. V. G. & 3 & 3 & 3 & 3 \\
\hline 28. W. A. V. B. & 1 & 2 & 1 & 1 \\
\hline
\end{tabular}


As tabelas A7 e A8 apresentam os valores individuais das grandezas cefalométricas na fase pré-tratamento dos pacientes do grupo 1 e do grupo 2 respectivamente

Tabela A7 - Valores cefalométricos pré-tratamento do grupo 1

\begin{tabular}{l|c|c|c|c|c}
\hline Paciente & $\begin{array}{c}\text { Trespasse } \\
\text { Horizontal }(\mathbf{m m})\end{array}$ & $\begin{array}{c}\text { Sobrepasse } \\
\text { Vertical }(\mathbf{m m})\end{array}$ & IS.PP & AIS-PP & $\begin{array}{c}\text { AIS- } \\
\text { ENAperp }\end{array}$ \\
\hline 1. A. F. C. & 7,9 & 6,5 & 116,1 & 3,5 & 9 \\
\hline 2. A. M. & 12,80 & 5,2 & 132,1 & 9 & 17,8 \\
\hline 3. A. P. L. & 10,40 & 5,3 & 118,8 & 7,5 & 14,5 \\
\hline 4. B. T. N. & 5,3 & 3,5 & 106,8 & 4,3 & 9,7 \\
\hline 5. B. B. A. & 7,2 & 5,1 & 110,8 & 5,7 & 11,1 \\
\hline 6. B. L. L. & 3 & 5,7 & 102,7 & 2,7 & 9,7 \\
\hline 7. C. S. Z. & 3,2 & 4,1 & 105,4 & 4,2 & 9,6 \\
\hline 8. C. P. V. B. & 4,3 & 4,2 & 115,9 & 2,8 & 9,9 \\
\hline 9. D. B. & 7,8 & 3,6 & 119,8 & 0,7 & 10,9 \\
\hline 10. E. M. M. & 11,1 & 4 & 125 & 4,3 & 6,8 \\
\hline 11. E. S. P. & 5,9 & 6 & 109,9 & 7,2 & 8,9 \\
\hline 12. H. E. T. C. & 8 & 3,5 & 127,1 & 5,3 & 7,5 \\
\hline 13. H. A. J. S. & 7,1 & 4,5 & 113,8 & 3,7 & 12,2 \\
\hline 14. I. A. M. & 3,5 & 8,7 & 95,2 & 3,9 & 11,5 \\
\hline 15. J. P. L. & 5,5 & 5,7 & 109,4 & 5,2 & 6 \\
\hline 16. J. C. P. & 10,5 & 5,2 & 118,6 & 4,6 & 13,3 \\
\hline 17. L. F. R. & 6,8 & 4 & 118,6 & 1,2 & 12,5 \\
\hline 18. L. E. B. & 5 & 5 & 114,4 & 2 & 8,5 \\
\hline 19. M. C. & 4,2 & 4,1 & 119,2 & 3,8 & 7,1 \\
\hline 20. M. E. A. P. & 6,4 & 6,3 & 110,3 & 6,9 & 8,6 \\
\hline 21. M. S. & 8,7 & 3,5 & 124,5 & 7,4 & 8,8 \\
\hline 22. P. C. P. & 3,2 & 4,5 & 109,9 & 2,9 & 7,2 \\
\hline 23. P. R. L. & 5,3 & 4,2 & 113,4 & 3,8 & 8,5 \\
\hline 24. P. G. O. & 6,3 & 5,4 & 105,4 & 1,9 & 8,7 \\
\hline 25. R. R. M. & 4,7 & 3,5 & 106,3 & 1,3 & 10,9 \\
\hline 26. R. P. O. & 5,2 & 4,8 & 99,1 & 7,3 & 5,9 \\
\hline 27. T. D. S. & 7,5 & 4,4 & 109 & 2,2 & 12,4 \\
\hline 28. V. C. R. & 4,9 & 3,5 & 109,6 & 6,1 & 7,6 \\
\hline
\end{tabular}


Tabela A8 - Valores cefalométricos pré-tratamento do grupo 2

\begin{tabular}{l|c|c|c|c|c}
\hline \multicolumn{1}{c|}{ Paciente } & $\begin{array}{c}\text { Trespasse } \\
\text { Horizontal }(\mathbf{m m})\end{array}$ & $\begin{array}{c}\text { Sobrepasse } \\
\text { Vertical } \mathbf{( m m})\end{array}$ & IS.PP & AIS-PP & $\begin{array}{c}\text { AIS- } \\
\text { ENAperp }\end{array}$ \\
\hline 1. A. C. & 5,9 & 0,2 & 118,9 & 4,5 & 9,9 \\
\hline 2. A. L. P. L. & 7,5 & 0,2 & 108,7 & 5,7 & 10 \\
\hline 3. C. H. P. & 3,1 & 2,7 & 104,3 & 7,7 & 11,3 \\
\hline 4. C. C. O. & 7,2 & 0,2 & 124,9 & 6,4 & 11,5 \\
\hline 5. C. P. M. & 11,9 & 0,3 & 127,3 & 12,1 & 13,3 \\
\hline 6. E. C. & 4,2 & 0,5 & 113,2 & 4,9 & 8,3 \\
\hline 7. F. L. S. & 5,8 & 2,6 & 116,5 & 5 & 8,4 \\
\hline 8. F. R. P. L. & 7,3 & 0,4 & 112,4 & 9,7 & 17,4 \\
\hline 9. F. N. & 3,7 & 1,6 & 111,3 & 1,3 & 8,6 \\
\hline 10. F. P. N. & 4,9 & 0,1 & 116,4 & 6,6 & 12,4 \\
\hline 11. H. C. G. & 6,4 & 1,6 & 110,8 & 7,5 & 14,1 \\
\hline 12. J. L. T. C. & 14,3 & 0,1 & 125,8 & 5,6 & 16,8 \\
\hline 13. J. E. S. C. & 3,8 & 1 & 118,9 & 4 & 11,2 \\
\hline 14. J. F. S. L. & 6,8 & 1,5 & 121,3 & 1,6 & 10,5 \\
\hline 15. J. R. D. & 3,4 & 3,8 & 107,1 & 1,3 & 7,9 \\
\hline 16. K. T. & 2,9 & 0,9 & 117,7 & 4,9 & 13,4 \\
\hline 17. L. F. R. & 6,8 & 1,3 & 117,2 & 0,7 & 12 \\
\hline 18. L. G. C. & 4,7 & 2,2 & 105,1 & 4,6 & 12,7 \\
\hline 19. M. M. B. & 6,1 & 0,9 & 113,7 & 2,8 & 8,5 \\
\hline 20. M. P. P. & 3,8 & 1,5 & 105,7 & 6 & 9 \\
\hline 21. M. R. & 3,3 & 2,2 & 104,2 & 5 & 8,3 \\
\hline 22. M. A. P. P. & 4,6 & 1,1 & 110,2 & 2,4 & 9,2 \\
\hline 23. M. A. O. S. & 2,6 & 2,4 & 107,4 & 10,6 & 6,1 \\
\hline 24. M. G. B. & 5,2 & 0,8 & 117,2 & 7,5 & 9,4 \\
\hline 25. R. N. C. & 2,9 & 0,5 & 109,5 & 4,1 & 10,2 \\
\hline 26. U. C. S. & 3,2 & 0,7 & 114,4 & 0,7 & 10,5 \\
\hline 27. V. G. & 8,3 & 0,1 & 118 & 5,5 & 13,5 \\
\hline 28. W. A. V. B. & 8,2 & 0,2 & 122,2 & 8,1 & 7,6 \\
\hline & & & & & \\
\hline & & & & & \\
\hline
\end{tabular}


As tabelas A9 e A10 apresentam os valores obtidos na segunda medição das grandezas cefalométricos de 15 pacientes de cada grupo na fase pré-tratamento para averiguação do erro do método e concordância inter-examinadores, respectivamente

Tabela A9 - Segunda medição dos valores cefalométricos pré-tratamento do grupo 1 para averiguação do erro do método

\begin{tabular}{l|c|c|c|c|c}
\hline \multicolumn{1}{c|}{ Paciente } & $\begin{array}{c}\text { Trespasse } \\
\text { Horizontal }(\mathbf{m m})\end{array}$ & $\begin{array}{c}\text { Sobrepasse } \\
\text { Vertical }(\mathbf{m m})\end{array}$ & IS.PP & AIS-PP & $\begin{array}{c}\text { AIS- } \\
\text { ENAperp }\end{array}$ \\
\hline 5. B. B. A. & 6,4 & 5,3 & 110,5 & 5,2 & 9,4 \\
\hline 6. B. L. L. & 2,9 & 6,3 & 102,2 & 3,2 & 10,5 \\
\hline 9. D. B. P. & 8,1 & 3,8 & 120,3 & 0,3 & 10,9 \\
\hline 10. E. M. M. & 10,8 & 5,3 & 123,5 & 4,8 & 6,2 \\
\hline 11. E. S. P. & 5,2 & 5,2 & 111,7 & 5,6 & 11 \\
\hline 12. H. E. T. C. & 8,5 & 2,4 & 126,7 & 5 & 7,5 \\
\hline 13. H. A. J. S. & 6,1 & 3,8 & 112,5 & 3,9 & 10,5 \\
\hline 15. J. P. L. & 5,3 & 6,2 & 107,5 & 4,5 & 5 \\
\hline 17. L. F. R. & 6,5 & 4,4 & 118,2 & 1,4 & 11,7 \\
\hline 18. L. E. B. & 5,4 & 4,5 & 113,2 & 2,4 & 8,1 \\
\hline 19. M. C. & 4,6 & 4,2 & 117,3 & 5,2 & 4,7 \\
\hline 22. P. C. P. & 3,8 & 4,4 & 110,7 & 3 & 6,8 \\
\hline 25. R. R. M. & 5,1 & 2,5 & 107,7 & 2,1 & 11 \\
\hline 26. R. P. O. & 5,3 & 4,5 & 99,6 & 7,2 & 6,1 \\
\hline 28. V. C. R. & 4,4 & 4,6 & 110,8 & 5,1 & 6,3 \\
\hline
\end{tabular}

Tabela A10 - Valores cefalométricos pré-tratamento do grupo 2 obtidos pelo $2^{\circ}$ examinador para averiguação da concordância inter-examinadores

\begin{tabular}{l|c|c|c|c|c}
\hline \multicolumn{1}{c|}{ Paciente } & $\begin{array}{c}\text { Trespasse } \\
\text { Horizontal } \mathbf{( m m})\end{array}$ & $\begin{array}{c}\text { Sobrepasse } \\
\text { Vertical }(\mathbf{m m})\end{array}$ & IS.PP & AIS-PP & $\begin{array}{c}\text { AIS- } \\
\text { ENAperp }\end{array}$ \\
\hline 1. A. C. & 6 & 0 & 115,7 & 4,3 & 9,3 \\
\hline 2. A. L. P. L. & 7,6 & 0 & 108,4 & 4,7 & 8,8 \\
\hline 3. C. H. P. & 5,2 & 4,4 & 105,4 & 6,7 & 12,7 \\
\hline 5. C. P. M. & 11,6 & 0 & 123,5 & 11,1 & 12,1 \\
\hline 6. E. C. & 6,3 & 0 & 116,7 & 5,7 & 9,3 \\
\hline 7. F. L. S. & 5,6 & 4,1 & 115,7 & 3,6 & 8,6 \\
\hline 10. F. P. N. & 5 & 1,1 & 113,3 & 7,2 & 10,7 \\
\hline 11. H. C. G. & 6,6 & 0 & 110,9 & 4,4 & 12,9 \\
\hline 12. J. L. T. C. & 13,9 & 0 & 127,5 & 6,6 & 16,3 \\
\hline 13. J. E. S. C. & 3,5 & 1,4 & 119,9 & 4,5 & 13 \\
\hline 14. J. F. S. L. & 6,7 & 0,5 & 123,2 & 1,9 & 13,4 \\
\hline 21. M. R. & 2,9 & 2,8 & 108,4 & 5,4 & 9,2 \\
\hline 24. M. G. B. & 4,9 & 1,1 & 118,6 & 8,1 & 10,1 \\
\hline 25. R. N. C. & 2 & 0,5 & 107,3 & 4,6 & 10,3 \\
\hline 26. U. C. S. & 2,2 & 0,1 & 112,7 & 1,3 & 10,5 \\
\hline
\end{tabular}


As tabelas A11 e A12 apresentam os valores individuais das grandezas cefalométricas na fase pós-tratamento dos pacientes do grupo 1 e do grupo 2 respectivamente

Tabela A11 - Valores cefalométricos pós-tratamento do grupo 1

\begin{tabular}{l|c|c|c|c|c}
\hline \multicolumn{1}{|c|}{ Paciente } & $\begin{array}{c}\text { Trespasse } \\
\text { Horizontal }(\mathbf{m m})\end{array}$ & $\begin{array}{c}\text { Sobrepasse } \\
\text { Vertical }(\mathbf{m m})\end{array}$ & IS.PP & AIS-PP & $\begin{array}{c}\text { AIS- } \\
\text { ENAperp }\end{array}$ \\
\hline 1. A. F. C. & 2,3 & 2,5 & 112,2 & 1,1 & 13,8 \\
\hline 2. A. M. & 5,1 & 2,5 & 118 & 6,8 & 19,9 \\
\hline 3. A. P. L. & 4,5 & 1,9 & 98,9 & 7,2 & 13,4 \\
\hline 4. B. T. N. & 2,1 & 1,1 & 110,8 & 4 & 13 \\
\hline 5. B. B. A. & 2,1 & 2,3 & 111,1 & 4,6 & 11,3 \\
\hline 6. B. L. L. & 2,4 & 2,3 & 115 & 4 & 15,2 \\
\hline 7. C. S. Z. & 2,3 & 2,1 & 111 & 6,1 & 11,5 \\
\hline 8. C. P. V. B. & 2,7 & 1,4 & 117,3 & 2,6 & 15,1 \\
\hline 9. D. B. P. & 2,9 & 2,2 & 126,5 & 2,8 & 16,3 \\
\hline 10. E. M. M. & 2,2 & 2,9 & 115 & 5,4 & 7 \\
\hline 11. E. S. P. & 1,2 & 1 & 110,1 & 5,9 & 13 \\
\hline 12. H. E. T. C. & 6,4 & 1,5 & 118,1 & 5,2 & 9,5 \\
\hline 13. H. A. J. S. & 3,7 & 0,8 & 108,3 & 5,4 & 11,7 \\
\hline 14. I. A. M. & 2,6 & 3,1 & 105,9 & 2,9 & 14,5 \\
\hline 15. J. P. L. & 1,8 & 3 & 104,6 & 4,2 & 10,9 \\
\hline 16. J. C. P. & 1,8 & 1,2 & 109,2 & 5,9 & 19,2 \\
\hline 17. L. F. R. & 2,6 & 0,1 & 117,7 & 1 & 12,7 \\
\hline 18. L. E. B. & 3,1 & 1,8 & 125,3 & 3,4 & 14,9 \\
\hline 19. M. C. & 2,9 & 3,1 & 109,7 & 5,1 & 12,3 \\
\hline 20. M. E. A. P. & 2,1 & 2,1 & 102,1 & 3 & 10,1 \\
\hline 21. M. S. & 1,4 & 1,5 & 104,7 & 5,5 & 7,1 \\
\hline 22. P. C. P. & 2,2 & 1,6 & 115,3 & 3,3 & 10,4 \\
\hline 23. P. R. L. & 2,1 & 2,7 & 105,4 & 5,1 & 10,9 \\
\hline 24. P. G. O. & 2,4 & 2,8 & 107,3 & $-1,5$ & 9,2 \\
\hline 25. R. R. M. & 1 & 1,3 & 103,4 & 1,6 & 14,3 \\
\hline 26. R. P. O. & 2,3 & 1,7 & 106,2 & 9,3 & 12,1 \\
\hline 27. T. D. S. & 1,9 & 2,2 & 110,9 & 3,8 & 13,2 \\
\hline 28. V. C. R. & 2,3 & 1,6 & 118,9 & 5,5 & 13,6 \\
\hline
\end{tabular}


Tabela A12 - Valores cefalométricos pós-tratamento do grupo 2

\begin{tabular}{l|c|c|c|c|c}
\hline \multicolumn{1}{c|}{ Paciente } & $\begin{array}{c}\text { Trespasse } \\
\text { Horizontal }(\mathbf{m m})\end{array}$ & $\begin{array}{c}\text { Sobrepasse } \\
\text { Vertical (mm) }\end{array}$ & IS.PP & AIS-PP & $\begin{array}{c}\text { AIS- } \\
\text { ENAperp }\end{array}$ \\
\hline 1. A. C. & 3,7 & 1,1 & 113,9 & 4,9 & 14,1 \\
\hline 2. A. L. P. L. & 2 & 0,6 & 101,1 & 4,9 & 11,4 \\
\hline 3. C. H. P. & 2,9 & 0,8 & 114,8 & 8,7 & 14,1 \\
\hline 4. C. C. O. & 2,5 & 0,7 & 106,4 & 6,2 & 12,3 \\
\hline 5. C. P. M. & 3,9 & 2,1 & 115 & 11,8 & 12,3 \\
\hline 6. E. C. & 2,8 & 1 & 111,3 & 4 & 10,7 \\
\hline 7. F. L. S. & 2,4 & 1,5 & 113,1 & 2 & 11,2 \\
\hline 8. F. R. P. L. & 2,7 & 1,8 & 106,1 & 7,8 & 18,6 \\
\hline 9. F. . S. & 2,5 & 1,1 & 110,3 & 1,9 & 10,6 \\
\hline 10. F. P. N. & 3,9 & 2,5 & 119,3 & 7,4 & 15 \\
\hline 11. H. C. G. & 3,8 & 0,3 & 111,8 & 8,7 & 17,2 \\
\hline 12. J. L. T. C. & 3,2 & 3,4 & 104,9 & 7,3 & 14,5 \\
\hline 13. J. E. S. C. & 3,5 & 0 & 115,4 & 4,8 & 12,6 \\
\hline 14. J. F. S. L. & 4,1 & 1,8 & 123,5 & 2,6 & 14,8 \\
\hline 15. J. R. D. & 3 & 2 & 121,9 & 0,8 & 12,1 \\
\hline 16. K. T. & 2,8 & 1,4 & 114 & 4,8 & 11,4 \\
\hline 17. L. F. R. & 2,3 & 0,1 & 118,9 & 1,9 & 12,9 \\
\hline 18. L. G. C. & 3,8 & 1,8 & 111,5 & 6,8 & 14,5 \\
\hline 19. M. M. B. & 3,5 & 0,7 & 119,3 & 1,9 & 13,5 \\
\hline 20. M. P. P. & 2,4 & $-0,3$ & 111,7 & 6,9 & 13 \\
\hline 21. M. R. & 2,3 & 1,2 & 115,6 & 5,8 & 14,5 \\
\hline 22. M. A. P. P. & 3,5 & 2,1 & 103,2 & 0,4 & 10,2 \\
\hline 23. M. A. O. S. & 3,4 & 1,4 & 119,1 & 9,7 & 12,3 \\
\hline 24. M. G. B. & 2,4 & 0,7 & 110,2 & 5,3 & 11,1 \\
\hline 25. R. N. C. & 2,2 & 0,9 & 114,9 & 3,1 & 13,4 \\
\hline 26. U. C. S. & 3,5 & 2,2 & 114,8 & 1,1 & 12,7 \\
\hline 27. V. G. & 2,3 & 1,7 & 101,2 & 6,4 & 15,8 \\
\hline 28. W. A. V. B. & 3 & 1,4 & 109,2 & 7,6 & 13,5 \\
\hline & & & & & \\
\hline
\end{tabular}


As tabelas A13 e A14 apresentam os valores obtidos na segunda medição das grandezas cefalométricos de 15 pacientes de cada grupo na fase póstratamento para averiguação do erro do método e concordância interexaminadores, respectivamente

Tabela A13 - Segunda medição dos valores cefalométricos pós-tratamento do grupo 1 para averiguação do erro do método

\begin{tabular}{l|c|c|c|c|c}
\hline \multicolumn{1}{c|}{ Paciente } & $\begin{array}{c}\text { Trespasse } \\
\text { Horizontal }(\mathbf{m m})\end{array}$ & $\begin{array}{c}\text { Sobrepasse } \\
\text { Vertical }(\mathbf{m m})\end{array}$ & IS.PP & AIS-PP & $\begin{array}{c}\text { AIS- } \\
\text { ENAperp }\end{array}$ \\
\hline 5. B. B. A. & 1,8 & 2,7 & 110,2 & 4,9 & 11,2 \\
\hline 6. B. L. L. & 2,6 & 2,9 & 115,2 & 4 & 15,2 \\
\hline 9. D. B. P. & 3,5 & 2 & 129,1 & 3,5 & 16 \\
\hline 10. E. M. M. & 2,6 & 2,7 & 115,1 & 5,2 & 6,7 \\
\hline 11. E. S. P. & 1,4 & 0,8 & 113 & 6,7 & 13,4 \\
\hline 12. H. E. T. C. & 6,5 & 2,1 & 117,8 & 4,7 & 9,5 \\
\hline 13. H. A. J. S. & 4,3 & 0,6 & 109,1 & 5,3 & 12,3 \\
\hline 15. J. P. L. & 1,9 & 3 & 103,1 & 4,2 & 9,9 \\
\hline 17. L. F. R. & 2,3 & 0,3 & 118 & 1,1 & 13,1 \\
\hline 18. L. E. B. & 2,3 & 1,5 & 125,8 & 3,5 & 14,8 \\
\hline 19. M. C. & 2,9 & 3,2 & 110,4 & 5,2 & 11,2 \\
\hline 22. P. C. P. & 2,1 & 1,5 & 114,4 & 3,5 & 10,1 \\
\hline 25. R. R. M. & 1,4 & 1,1 & 103,1 & 1,6 & 13,5 \\
\hline 26. R. P. O. & 2,7 & 2 & 107,8 & 9,1 & 11,9 \\
\hline 28. V. C. R. & 2,3 & 1,5 & 119 & 5,2 & 13,1 \\
\hline
\end{tabular}

Tabela A14 - Valores cefalométricos pós-tratamento do grupo 2 obtidos pelo $2^{\circ}$ examinador para averiguação da concordância inter-examinadores

\begin{tabular}{l|c|c|c|c|c}
\hline \multicolumn{1}{c|}{ Paciente } & $\begin{array}{c}\text { Trespasse } \\
\text { Horizontal }(\mathbf{m m})\end{array}$ & $\begin{array}{c}\text { Sobrepasse } \\
\text { Vertical }(\mathbf{m m})\end{array}$ & IS.PP & AIS-PP & $\begin{array}{c}\text { AIS- } \\
\text { ENAperp }\end{array}$ \\
\hline 1. A. C. & 3,2 & 1,3 & 118,5 & 6,7 & 9,7 \\
\hline 2. A. L. P. L. & 2,1 & 1 & 102,3 & 5,5 & 11,9 \\
\hline 3. C. H. P. & 3,6 & 1 & 115,6 & 6,5 & 17,5 \\
\hline 5. C. P. M. & 3,5 & 2,6 & 112,6 & 10,9 & 13,4 \\
\hline 6. E. C. & 1,8 & 1,4 & 108,5 & 4 & 11,3 \\
\hline 7. F. L. S. & 2,7 & 1,6 & 112,9 & 2,5 & 10,2 \\
\hline 10. F. P. N. & 2,9 & 2,2 & 115,2 & 6,3 & 15,9 \\
\hline 11. H. C. G. & 4,4 & 0 & 114,2 & 7,9 & 18 \\
\hline 12. J. L. T. C. & 3,5 & 3,4 & 103 & 8,2 & 19,4 \\
\hline 13. J. E. S. C. & 4,1 & 1,2 & 113,2 & 4,9 & 13 \\
\hline 14. J. F. S. L. & 4 & 0,6 & 120,5 & 2,6 & 13,4 \\
\hline 21. M. R. & 2 & 0,9 & 118,7 & 7 & 15,3 \\
\hline 24. M. G. B. & 1,7 & 1,9 & 109,8 & 6 & 12,1 \\
\hline 25. R. . C. & 1,8 & 1,5 & 114,8 & 4 & 12,8 \\
\hline 26. U. C. S. & 3,1 & 2,4 & 117,4 & 1,9 & 13,1 \\
\hline
\end{tabular}


As tabelas A15 e A16 apresentam os valores das alterações cefalométricas ocasionadas pelo tratamento em cada paciente do grupo 1 e do grupo 2 respectivamente

Tabela A15 - Alterações cefalométricas causadas pelo tratamento no grupo 1 (final - inicial)

\begin{tabular}{l|c|c|c|c|c}
\hline Paciente & $\begin{array}{c}\text { Trespasse } \\
\text { Horizontal }(\mathbf{m m})\end{array}$ & $\begin{array}{c}\text { Sobrepasse } \\
\text { Vertical }(\mathbf{m m})\end{array}$ & IS.PP & AIS-PP & $\begin{array}{c}\text { AIS- } \\
\text { ENAperp }\end{array}$ \\
\hline 1. A. F. C. & $-5,6$ & -4 & $-3,9$ & $-2,4$ & 4,8 \\
\hline 2. A. M. & $-7,7$ & $-2,7$ & $-14,1$ & $-2,2$ & 2,1 \\
\hline 3. A. P. L. & $-5,9$ & $-3,4$ & $-19,9$ & $-0,3$ & $-1,1$ \\
\hline 4. B. T. N. & $-3,2$ & $-2,4$ & 4 & $-0,3$ & 3,3 \\
\hline 5. B. B. A. & $-5,1$ & $-2,8$ & 0,3 & $-1,1$ & 0,2 \\
\hline 6. B. L. L. & $-0,6$ & $-3,4$ & 12,3 & 1,3 & 5,5 \\
\hline 7. C. S. Z. & $-0,9$ & -2 & 5,6 & 1,9 & 1,9 \\
\hline 8. C. P. V. B. & $-1,6$ & $-2,8$ & 1,4 & $-0,2$ & 5,2 \\
\hline 9. D. B. P. & $-4,9$ & $-1,4$ & 6,7 & 2,1 & 5,4 \\
\hline 10. E. M. M. & $-8,9$ & $-1,1$ & -10 & 1,1 & 0,2 \\
\hline 11. E. S. P. & $-4,7$ & -5 & 0,2 & $-1,3$ & 4,1 \\
\hline 12. H. E. T. C. & $-1,6$ & -2 & -9 & $-0,1$ & 2 \\
\hline 13. H. A. J. S. & $-3,4$ & $-3,7$ & $-5,5$ & 1,7 & $-0,5$ \\
\hline 14. I. A. M. & $-0,9$ & $-5,6$ & 10,7 & -1 & 3 \\
\hline 15. J. P. L. & $-3,7$ & $-2,7$ & $-4,8$ & -1 & 4,9 \\
\hline 16. J. C. P. & $-8,7$ & -4 & $-9,4$ & 1,3 & 5,9 \\
\hline 17. L. F. R. & $-4,2$ & $-3,9$ & $-0,9$ & $-0,2$ & 0,2 \\
\hline 18. L. E. B. & $-1,9$ & $-3,2$ & 10,9 & 1,4 & 6,4 \\
\hline 19. M. C. & $-1,3$ & -1 & $-9,5$ & 1,3 & 5,2 \\
\hline 20. M. E. A. P. & $-4,3$ & $-4,2$ & $-8,2$ & $-3,9$ & 1,5 \\
\hline 21. M. S. & $-7,3$ & -2 & $-19,8$ & $-1,9$ & $-1,7$ \\
\hline 22. P. C. P. & -1 & $-2,9$ & 5,4 & 0,4 & 3,2 \\
\hline 23. P. R. L. & $-3,2$ & $-1,5$ & -8 & 1,3 & 2,4 \\
\hline 24. P. G. O. & $-3,9$ & $-2,6$ & 1,9 & $-3,4$ & 0,5 \\
\hline 25. R. R. M. & $-3,7$ & $-2,2$ & $-2,9$ & 0,3 & 3,4 \\
\hline 26. R. P. O. & $-2,9$ & $-3,1$ & 7,1 & 2 & 6,2 \\
\hline 27. T. D. S. & $-5,6$ & $-2,2$ & 1,9 & 1,6 & 0,8 \\
\hline 28. V. C. R. & $-2,6$ & $-1,9$ & 9,3 & $-0,6$ & 6 \\
\hline & & & & & \\
\hline
\end{tabular}


Tabela A16 - Alterações cefalométricas causadas pelo tratamento no grupo 2 (final - inicial)

\begin{tabular}{|c|c|c|c|c|c|}
\hline Paciente & $\begin{array}{c}\text { Trespasse } \\
\text { Horizontal (mm) }\end{array}$ & $\begin{array}{l}\text { Sobrepasse } \\
\text { Vertical }(\mathrm{mm})\end{array}$ & IS.PP & AIS-PP & $\begin{array}{c}\text { AIS- } \\
\text { ENAperp }\end{array}$ \\
\hline 1. A. C. & $-2,2$ & 0,9 & -5 & 0,4 & 4,2 \\
\hline 2. A. L. P. L. & $-5,5$ & 0,4 & $-7,6$ & $-0,8$ & 1,4 \\
\hline 3. C. H. P. & $-0,2$ & $-1,9$ & 10,5 & 1 & 2,8 \\
\hline 4. C. C. O. & $-4,7$ & 0,5 & $-18,5$ & $-0,2$ & 0,8 \\
\hline 5. C. P. M. & -8 & 1,8 & $-12,3$ & $-0,3$ & -1 \\
\hline 6. E. C. & $-1,4$ & 0,5 & $-1,9$ & $-0,9$ & 2,4 \\
\hline 7. F. L. S. & $-3,4$ & $-1,1$ & $-3,4$ & -3 & 2,8 \\
\hline 8. F. R. P. L. & $-4,6$ & 1,4 & $-6,3$ & $-1,9$ & 1,2 \\
\hline 9. F. N. S. & $-1,2$ & $-0,5$ & -1 & 0,6 & 2 \\
\hline 10. F. P. N. & -1 & 2,4 & 2,9 & 0,8 & 2,6 \\
\hline 11. H. C. G. & $-2,6$ & $-1,3$ & 1 & 1,2 & 3,1 \\
\hline 12. J. L. T. C. & $-11,1$ & 3,3 & $-20,9$ & 1,7 & $-2,3$ \\
\hline 13. J. E. S. C. & $-0,3$ & -1 & $-3,5$ & 0,8 & 1,4 \\
\hline 14. J. F. S. L. & $-2,7$ & 0,3 & 2,2 & 1 & 4,3 \\
\hline 15. J. R. D. & $-0,4$ & $-1,8$ & 14,8 & $-0,5$ & 4,2 \\
\hline 16. K. T. & $-0,1$ & 0,5 & $-3,7$ & $-0,1$ & -2 \\
\hline 17. L. F. R. & $-4,5$ & $-1,2$ & 1,7 & 1,2 & 0,9 \\
\hline 18. L. G. C. & $-0,9$ & $-0,4$ & 6,4 & 2,2 & 1,8 \\
\hline 19. M. M. B. & $-2,6$ & $-0,2$ & 5,6 & $-0,9$ & 5 \\
\hline 20. M. P. P. & $-1,4$ & $-1,8$ & 6 & 0,9 & 4 \\
\hline 21. M. R. & -1 & -1 & 11,4 & 0,8 & 6,2 \\
\hline 22. M. A. P. P. & $-1,1$ & 1 & -7 & -2 & 1 \\
\hline 23. M. A. O. S. & 0,8 & -1 & 11,7 & $-0,9$ & 6,2 \\
\hline 24. M. G. B. & $-2,8$ & $-0,1$ & -7 & $-2,2$ & 1,7 \\
\hline 25. R. N. C. & $-0,7$ & 0,4 & 5,4 & -1 & 3,2 \\
\hline 26. U.C.S. & 0,3 & 1,5 & 0,4 & 0,4 & 2,2 \\
\hline 27. V. G. & -6 & 1,6 & $-16,8$ & 0,9 & 2,3 \\
\hline 28. W. A. V. B. & $-5,2$ & 1,2 & -13 & $-0,5$ & 5,9 \\
\hline
\end{tabular}




\section{Universidade de São Paulo \\ Faculdade de Odontologia de Bauru}

Al. Dr. Octávio Pinheiro Brisolla, 9-75 - Bauru-SP - CEP 17012-901 - C.P. 73

PABX (0XX14)3235-8000 - FAX (0XX14)3223-4679

Comitê de Ética em Pesquisa (3235-8356)

Processo $n^{\circ} 36 / 2005$

Bauru, 30 de novembro de 2006.

Senhor Professor,

Informamos que após o envio da documentação solicitada referente ao projeto de pesquisa encaminhado a este Comitê de Ética em Pesquisa "Influência da intrusão combinada à retração anterior sobre o grau de reabsorção apical conseqüente à movimentação dentária induzida" de autoria de Douglas Tibola sob sua orientação, foi novamente analisado e considerado APROVADO em reunião deste Comitê, realizada no dia 29 de novembro de 2006.

Solicitamos que ao término do trabalho, seja enviado a este Colegiado um relatório final para parecer do trabalho concluído o qual será utilizado para publicação em revista científica.

Atenciosamente,

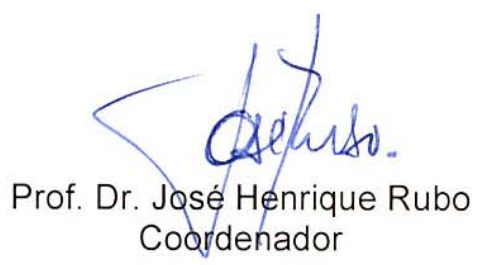

Prof. Dr. Décio Rodrigues Martins

Docente do Departamento de Odontopediatria, Ortodontia e Saúde Coletiva 